\author{
ZENTRUM \\ FÜR BIODIVERSITÄT UND NACHHALTIGE LANDNUTZUNG \\ SEKTION \\ BIODIVERSITÄT, ÖKOLOGIE UND NATURSCHUTZ \\ - Centre of Biodiversity ANd Sustainable LAND USE - \\ SECTION: BIOdIVERsity, ECOlogy and NATURE CONSERVATION
}

\title{
Community structure, trophic ecology and reproductive mode of oribatid mites (Oribatida, Acari) in forest ecosystems
}

\author{
Dissertation zur Erlangung des Doktorgrades der \\ Mathematisch-Naturwissenschaftlichen Fakultäten der \\ Georg-August-Universität Göttingen
}

vorgelegt von

Diplom-Biologin

Georgia Erdmann

aus

Räckelwitz 
Koreferent:

Prof. Dr. Stefan Scheu

Tag der mündlichen Prüfung: $\quad$ 26.03.2012 


\section{Contents}

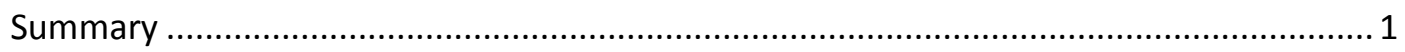

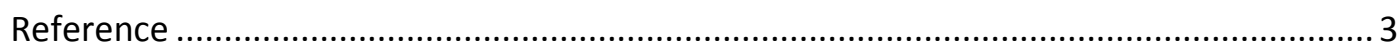

\section{Chapter 1}

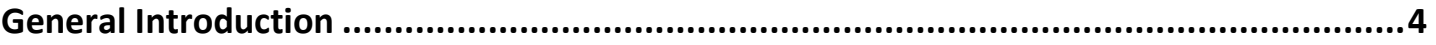

1. Density, diversity and distribution of oribatid mites …............................................ 5

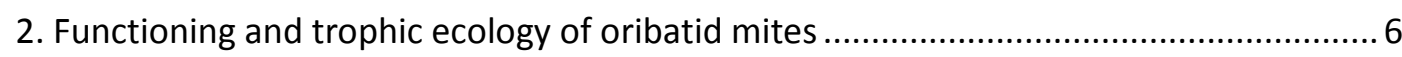

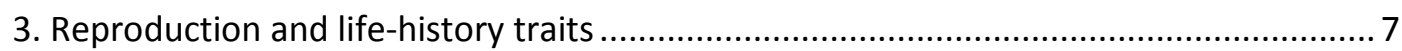

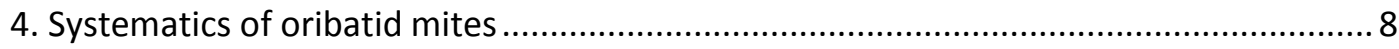

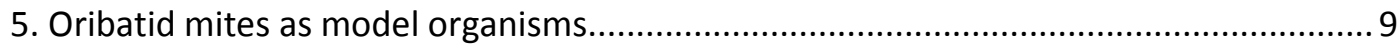

6. Theories about the maintenance of sexual reproduction.............................................. 10

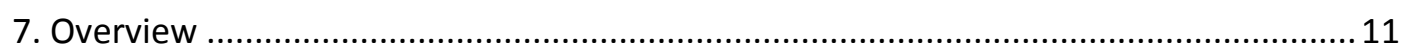

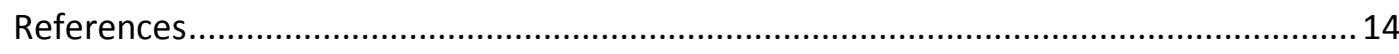

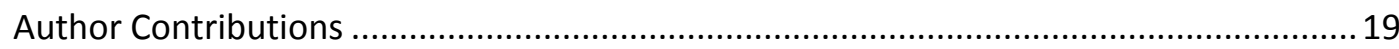

\section{Chapter 2}

Stable isotopes revisited: their use and limits for oribatid mite trophic ecology..............20

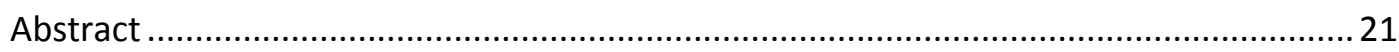

1. The history of the use of stable isotopes in soil food web analysis .............................. 21

2. Uncovering the trophic structure of oribatid mite communities................................23

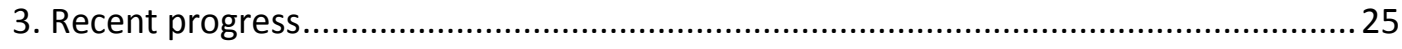

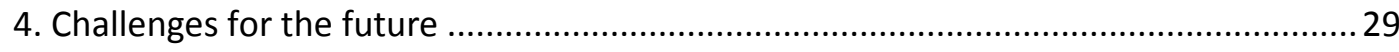

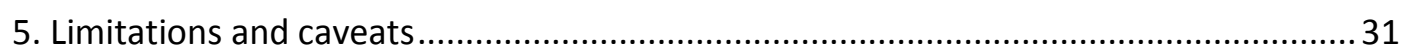

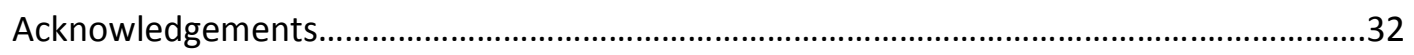

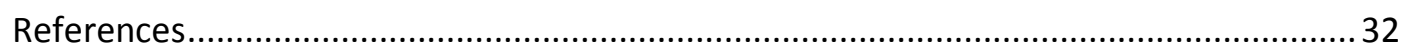

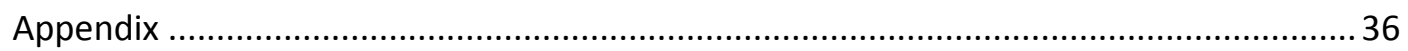




\section{Chapter 3}

Regional factors rather than forest type drive the community structure

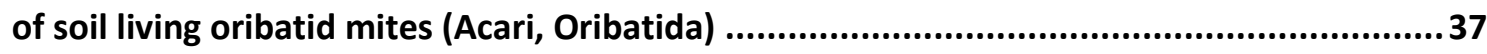

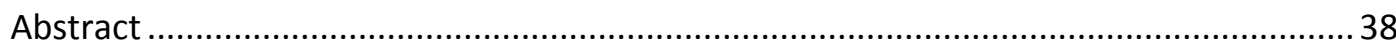

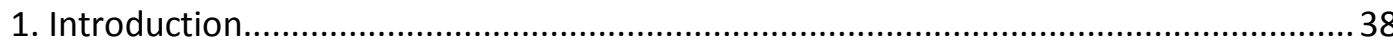

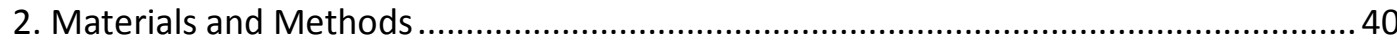

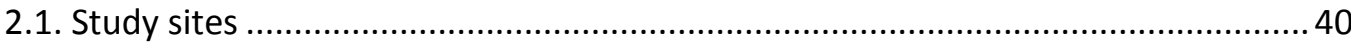

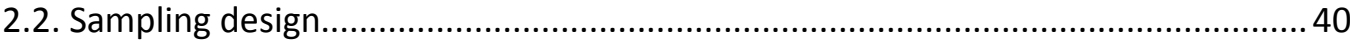

2.3. Environmental factors ......................................................................................... 41

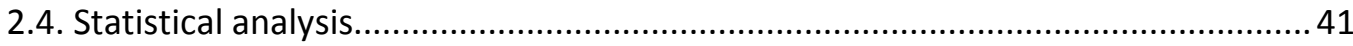

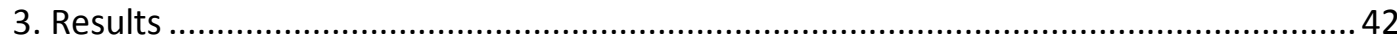

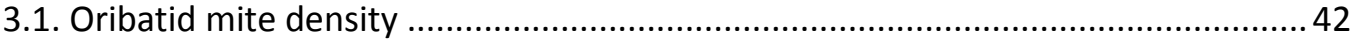

3.2. Species numbers of oribatid mites........................................................................ 43

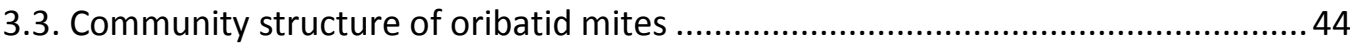

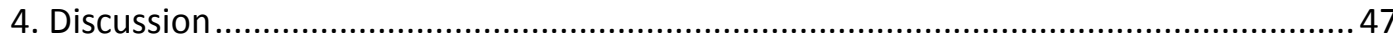

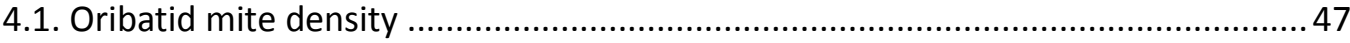

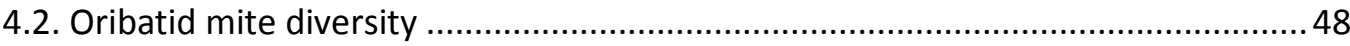

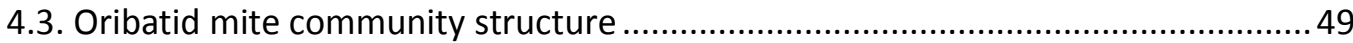

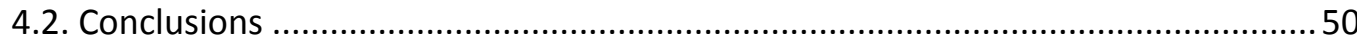

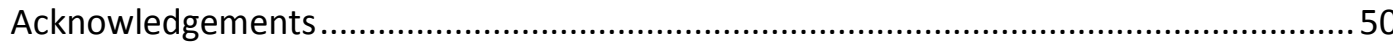

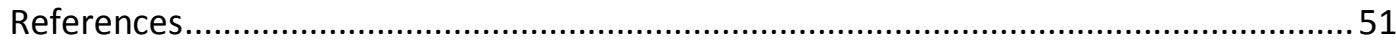

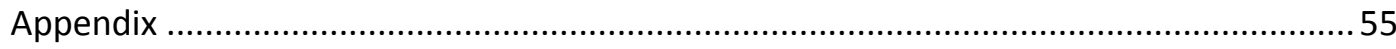

\section{Chapter 4}

Positive correlation between density and parthenogenetic reproduction in oribatid mites

(Acari) supports the structured resource theory of sexual reproduction ...............................56

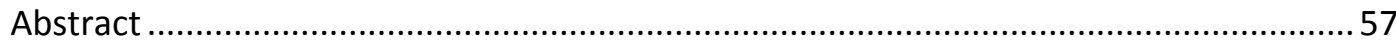

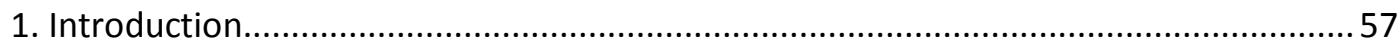

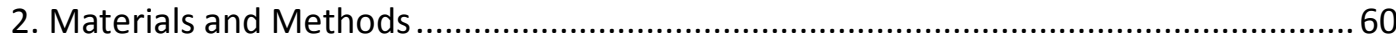

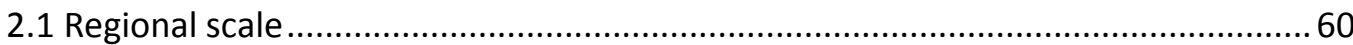




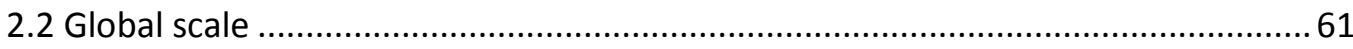

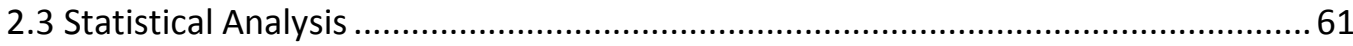

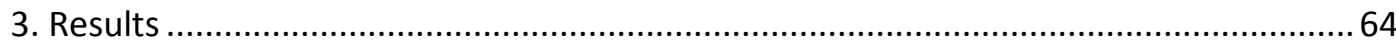

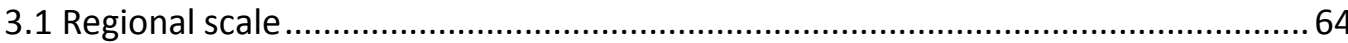

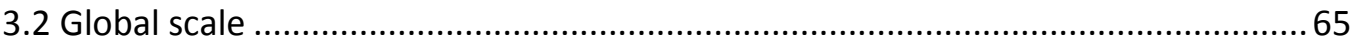

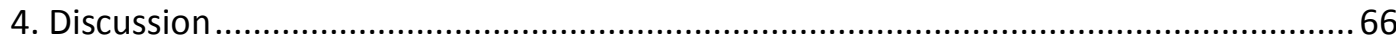

4.1 Parthenogenetic reproduction in oribatid mites .......................................66 66

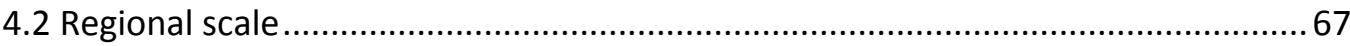

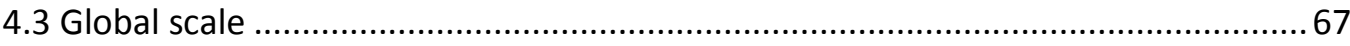

4.4 The structured resource theory of sexual reproduction as an integrative theory .. 68

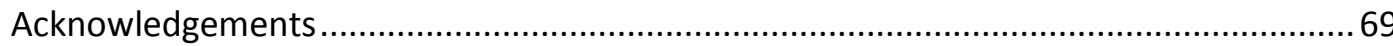

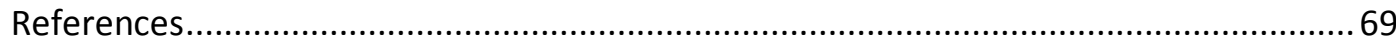

Literature used for the meta-analysis ........................................................ 72

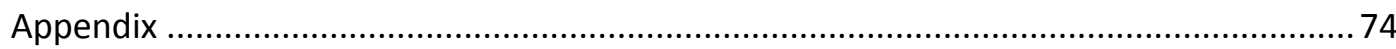

\section{Chapter 5}

Oribatid mite (Acari, Oribatida) density on tree trunks is regulated by food-resources $\ldots . . . .81$

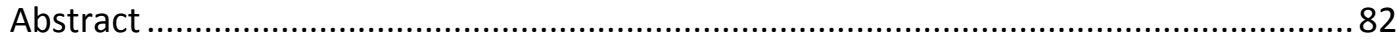

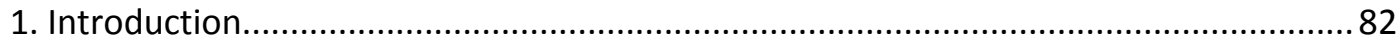

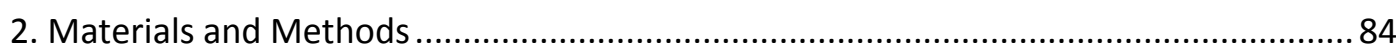

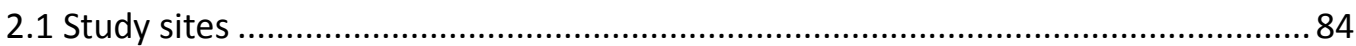

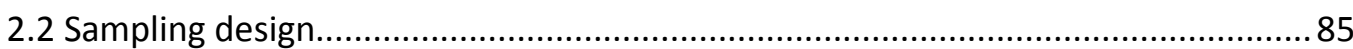

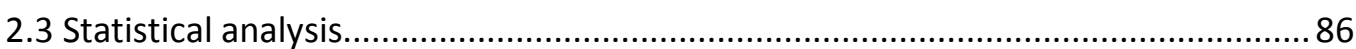

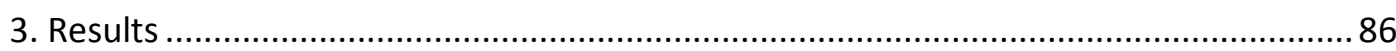

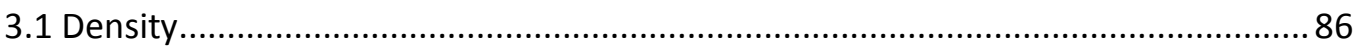

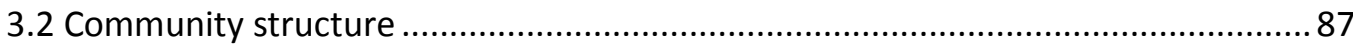

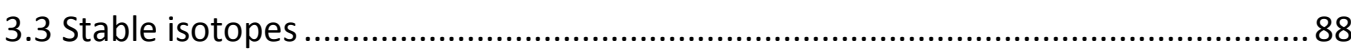

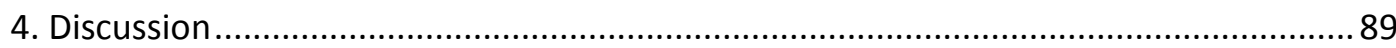

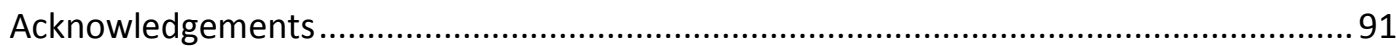

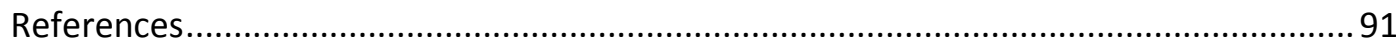

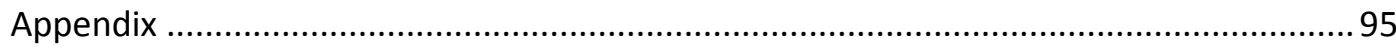




\section{Chapter 6}

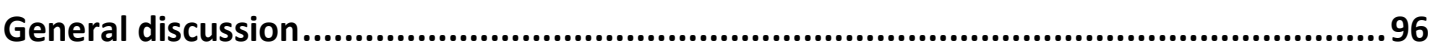

1. Stable isotope analysis of soil- and bark-living oribatid mites ................................ 98

2. Effect of forest types on oribatid mites ......................................................... 99

3. Frequency of parthenogenetic oribatid mites related to resources in soils ............... 101

4. Tree trunks - a resource-limited habitat for oribatid mites ................................ 102

5. Conclusions.......................................................................................... 103

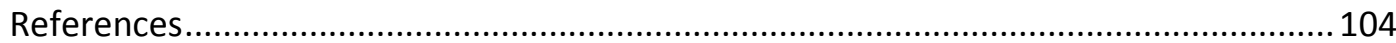

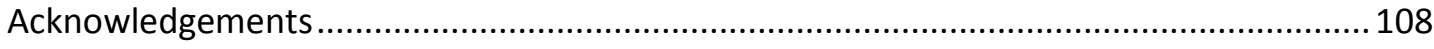

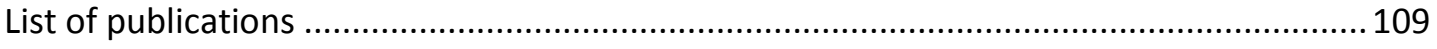

Thesis Declaration ......................................................................................... 110 


\section{Summary}

Oribatid mites are predominantly soil-living organisms reaching densities of up to 400,000 individuals per square meter in forest soils, where they contribute to decomposition processes and nutrient cycling. In acidic forests they are the main decomposer taxon, together with collembolans. Despite their outstanding importance for soil processes knowledge about their trophic ecology and factors structuring their communities is low.

About ten percent of the 10,000 described species are thelytokous (i.e., they reproduce via female parthenogenesis); locally up to $80 \%$ of all individuals in temperate forest soils are parthenogens. Oribatid mites likely originated in Cambrian or Precambrian times and include old thelytokous species-rich groups indicating an ancient origin of asexuality as well as parthenogenetic radiations. Sexual and parthenogenetic species coexist in forest soils and in agricultural soils; in temperate, tropical and arctic regions and also on the bark of dead and living trees. This makes oribatid mites a unique group for studying patterns of parthenogenetic reproduction and for studying factors influencing the relative frequency of sexual and parthenogenetic species (see

\section{Chapter 1).}

The present thesis focuses on oribatid mite reproductive mode and ecology and is divided into two parts. The first part investigates the trophic ecology of oribatid mites in soil and on bark analysed with stable isotope measurements (Chapter 2 ) and abiotic and biotic factors influencing oribatid mite density, diversity and community structure in soils of different forest types (Chapter $\mathbf{3}$ ). In the second part oribatid mites were used as model organisms to investigate the distribution of sexual and parthenogenetic individuals in forest soils in two regions in Germany and in different habitats worldwide in relation to food availability (Chapter 4). Further we investigated the effects of nutrient availability on oribatid mite density and the frequency of parthenogenetic individuals on tree trunks (Chapter 5).

In Chapter 2 we used two stable isotopes $\left({ }^{15} \mathrm{~N} ;{ }^{13} \mathrm{C}\right)$ for uncovering the trophic ecology of soil- and bark-living oribatid mites. The isotope ${ }^{15} \mathrm{~N}$ is usually used to detect the trophic level in food webs since it is enriched by about 3.4 delta units per trophic level, whereas ${ }^{13} \mathrm{C}$ can be a marker for different food sources since different food source s can differ in their ${ }^{13} \mathrm{C}$ signatures (e.g., lichens, $\mathrm{C} 4$ and C3 plants), but those signatures are not enriched per trophic levels. It could be shown that oribatid mites span over four trophic levels, which was surprising since usually oribatid mites are treated in food webs as a single functional group, i.e., decomposers. However, our data clearly show 
that oribatid mites are a trophically diverse group and should not be aggregated in food webs. Additionally, ${ }^{13} \mathrm{C}$ signatures separated lichen feeders as well as species that burrow inside leaves and needles as juveniles (endophagous taxa) from the other species.

In Chapter $\mathbf{3}$ we investigated the importance of regional versus local factors on oribatid mite community structure. Therefore, we studied oribatid mites in four differently managed forest types (coniferous 70y old age class forests; $30 \mathrm{y}$ old and $70 \mathrm{y}$ old beech age class forests, unmanaged beech forests mature with trees $\sim 120$ y old) (local effects) at three different sites in Germany (Swabian Alb, Hainich, Schorfheide) (regional effects) in the framework of the DFG project "Biodiversity Exploratories". We also measured environmental factors (litter mass, soil $\mathrm{pH}, \mathrm{C}$ and $\mathrm{N}$ content of litter and fine roots, $\mathrm{C}$ content of soil) which might potentially explain oribatid mite density and community structure. Oribatid mite density was positively correlated with litter mass supporting the hypothesis that the litter serves as a habitat and also as a food resource for many oribatid mite species. Oribatid mite diversity was little affected by forest type indicating that in most forest types the number of niches for oribatid mites is similar. Overall, differences of oribatid mite communities were more pronounced between the three regions than between the four forest types within a region indicating that regional factors (mainly $\mathrm{pH}$, litter mass and $\mathrm{C}$ content of litter) are more important than local factors for oribatid mite community structure. Overall, the predictability of density, diversity and community structure of oribatid mite communities in different regions indicates that oribatid mite communities are not randomly assembled.

In Chapter 4 we investigated the hypothesis that parthenogenetic species should dominate in habitats with a good food supply where resources are not a limiting factor. In contrast, in habitats where resources are in short supply or strongly structured sexual reproduction should dominate since mixis processes potentially allow a better use of underutilized resources ("Structured Resource Theory of Sexual Reproduction" (SRTS); Scheu and Drossel 2007). Our data show a strong positive relationship between parthenogenetic reproduction and density (which we used as an indirect measurement for resource availability) supporting the hypothesis that availability of food in ample supply triggers parthenogenesis and allows the long-term maintenance of parthenogenetic reproduction.

In Chapter $\mathbf{5}$ we experimentally investigated the hypothesis that increased resource availability increases the density of oribatid mites and also the prevalence of parthenogens. For this study we added nutrients in the form of cane sugar as a carbon source $(C)$ and ammonium nitrate as a nitrogen source $(\mathrm{N})$ on the tree trunks of beech trees (Fagus sylvatica). Oribatid mite density increased after $\mathrm{C}$ addition supporting the view that oribatid mites on the bark of trees are resource limited. However, the number of parthenogenetic individuals did not increase after resource addition (neither $\mathrm{C}$ or $\mathrm{N}$ ) 
which was mainly due to the fact that the bark is a habitat where sexual taxa dominate ( 95\%). Migration of parthenogens from soil obviously was too low to affect community sex ratios.

\section{Reference}

Scheu, S., Drossel, B. (2007) Sexual reproduction prevails in a world of structured resources in short supply. Proceedings of the Royal Society B - Biological Sciences 274, 1225-1231. 


\section{Chapter 1}

General Introduction 


\section{Density, diversity and distribution of oribatid mites}

Oribatid mites are typical soil living microarthropods reaching densities of up to 200,000 individuals per square meter in acidic raw humus of coniferous forests (Maraun and Scheu 2000). With increasing soil pH oribatid mite densities decrease to $\sim 20,000-60,000$ individuals per square meter in mull soils of deciduous forests (Maraun and Scheu 2000). They are also common in agricultural soils, such as pastures and fields, but have lower densities of $\sim 10,000$ individuals per square meter (Maraun and Scheu 2000). Living in almost all terrestrial habitats from deserts to polar regions, from fresh water to saltmarshes (Walter and Proctor 1999), oribatid mites are among the most abundant microarthropods in soil. Furthermore, oribatid mites also colonize a huge range of microhabitats including the surface of stones, lichens (Travé 1963, Gjelstrup and Sochting 1979), dead wood (Aoki 1967), tree trunks (Erdmann et al. 2006) and suspended soils in tree crowns (Lindo and Winchester 2007).

About 10,000 species of oribatid mites are described worldwide (Subias 2004, Schatz 2005) and a total number of 110,000 species is estimated to exist (Walter and Proctor 1999). On a global scale, diversity is lowest in Antarctica with 27 species (Stary and Block 1998) and increases with decreasing latitude being highest in boreal and the warm temperate regions, but does not increase further to the tropics (Maraun et al. 2007). In Germany 520 oribatid mite species are documented (Weigmann 2006) with typical numbers of 50-120 species in soil of single forests (Wunderle 1992, Norton and Behan-Pelletier 2009). Despite the seemingly homogeneous habitat soil organisms live in, the diversity of soil animals is very high (Giller 1996). This phenomenon has been termed the "enigma of soil animal diversity" (Anderson 1975).

Overall density and community composition at the level of morphological and functional groups is predictable over a broad range for habitat types (Maraun and Scheu 2000). Caruso et al. (2011) investigated the dissimilarity of oribatid mite communities in two habitats (Mediterranean beech forest and grassland) at different geographical distances (from centimeters to tens and hundreds of meters). To a large extent the variation in oribatid mite community composition in space was independent of measured environmental variables (e.g., organic matter), but the dissimilarity of the communities did not match predictions of neutral models. The results suggest that both stochastic and deterministic processes contribute to oribatid mite assemblage structure. 
The importance of bottom-up or top-down forces on oribatid mite communities is unclear and still debated (Salamon et al. 2006, Lenoir et al. 2007, Schneider and Maraun 2009). Predators of oribatid mites range from small vertebrates e.g., salamanders (Norton and McNamara 1978) and frogs (Saporito et al. 2007), over centipedes (Lebrun 1970) and insects, e.g., Scydmaenidae (Schuster 1966) and Formicidae (Wilson 2005), to other mites e.g,. Prostigmata and Mesostigmata (Wallwork 1980, Peschel et al. 2006). However, the impact of predation - at least for adult oribatid mites - is likely to be of minor importance. Oribatid mites are regarded as living in an enemy-free space due to chemical defense (Heethoff et al. 2011) and strongly hardened cuticle, but the latter is less pronounced in juveniles (Peschel et al. 2006). Perturbations have been shown to detrimentally affect oribatid mites (Maraun et al. 2003). Especially earthworms exert strong negative impacts on oribatid mite communities (Migge-Kleian et al. 2006, Eisenhauer 2010) which likely is due to litter comminution and mixing of litter and soil.

\section{Functioning and trophic ecology of oribatid mites}

Oribatid mites are predominantly decomposers, feeding on dead organic material and fungi. Especially in acidic soils (where earthworms are absent), oribatid mites carry out important decomposition processes (Lussenhop 1992) and play an important role in nutrient cycling, mineralization processes and humus formation (Krantz 2009). Further, they distribute fungal spores and bacteria that are attached to their body surface or transported in their gut which supports fungal colonization of dead organic material and decomposition processes (Maraun et al. 1998, Renker et al. 2005).

Different approaches, such as gut content analysis (Hubert et al. 2001), analysis of enzyme activities (Siepel and deReuiter-Dijkmann 1993), measuring of cheliceral sizes (Kaneko 1988) and laboratory feeding experiments (Schneider et al. 2005, Koukol et al. 2009), resulted in different systems of distinct feeding categories. Schneider et al. (2004) investigated stable isotope signatures of oribatid mites in soil and demonstrated that species feed in a continuous range of three to four trophic levels including phycophages/fungivores (lichen and algae), primary decomposers (predominantly feeding litter), secondary decomposers (predominantly consuming fungi and in part litter) and carnivores/scavengers/omnivores (feeding on living and dead animals, e.g., nematodes (Heidemann et al. 2011), springtails and potentially mycorrhizal fungi). 
Recent studies postulated that oribatid mites heavily rely on rhizosphere carbon (Pollierer et al. 2007). Additional micro habitats extend the variety of food resources oribatid mites feed on; e.g., oribatid mites on bark mainly feed on lichens and algae (Erdmann et al. 2007, Fischer et al. 2010a).

\section{Reproduction and life-history traits}

Oribatid mites are diplodiploid organisms with presumably holokinetic chromosomes (Norton et al. 1993). Females can easily be distinguished from males (Grandjean 1955, 1956) since females have a large ovipositor with a typical wavelike surface pattern. There are three pairs of genital papillae on the basis of the ovipositor. Throughout the year females carry eggs inside the notogaster. All three structures, ovipositor, genital papillae and eggs, can easily be seen under a microscope. The spermatophore depositor of the male is rather small and more difficult to see than the ovipositor.

Sperm transfer usually takes place indirectly via stalked spermatophores. Eggs are laid in crevices, where they develop from prelarvae, larvae, deutonymphs and tritonymphs to adult organisms. Lifetime fecundity of oribatid mites is low, compared to other mite groups (Norton 1994). They are considered as K-strategists with delayed maturity, low reproductive potential, iteroparity and long adult life (Norton 1994). The variation in generation times is high and fecundity differs seasonally. The species Oppiella nova carries single eggs and lays upto twelve eggs per week in culture (Woodring and Cook 1962) while Steganacarus magnus carries about six eggs and lays them at lengthy intervals (Webb 1989). Under laboratory conditions females of some species lay between six and twelve eggs during livetime (Nothrus biciliatus; Saichuae et al. 1972), whereas other females lay up to 250 eggs in a single year (Platynothrus peltifer; Grandjean 1950). Developmental rates vary in soils of the temperate zone between several months to over a year (Norton 1994). Sexual species had higher number of eggs than parthenogenetic species in laboratory experiments (Domes et al. 2007b). However, the total reproductive rate depends on generation time, mode of reproduction and number of eggs produced and is little understood (Domes et al. 2007b). Species with wide ecological distributions show a high degree of plasticity of life cycle duration with an elongation under cold conditions (Norton 1994).

Interestingly, ten percent of the approximately 10,000 described oribatid mite species (Subias 2004, Schatz 2005) are thelytokous i.e., females produce daughters from diploid eggs without fertilization by males. No males or very few non-functional (spanandric) males exist 
which do not genetically contribute to the next generation (Grandjean 1941, Taberly 1988, Palmer and Norton 1992, Norton et al. 1993).

The classification of parthenogenetic species was carried out on the basis of rearing experiments or is suspected from the absence or rarity of males in natural populations (Norton et al. 1993). While sexual species have a sex ratio of approximately 1:1 (lowest recorded sex ratio of $1 / 4.4$; Luxton 1981), the proportion of females in parthenogenetic species is $95-100 \%$ (Norton and Palmer 1991, Palmer and Norton 1992, Cianciolo and Norton 2006, Domes et al. 2007a). Cyclical or geographic parthenogenesis is not known for oribatid mites (Norton and Palmer 1991).

Meiotic processes are involved in the reproductive mechanism. Automoxis with terminal fusion is probably the most common mechanism (Taberly 1987, Heethoff et al. 2006), but central fusion automixis and apomixis were proposed to explain the fixed heterozygosity which was found for nine oribatid mite species using isozyme techniques (Palmer and Norton 1992), but were not confirmed by molecular data of elongation factor (ef1 $\alpha$ ) and heat-shock protein (hsp82) (Schaefer et al. 2006). Wrensch et al. (1994) suggested inverted meiosis of holokinetic chromosomes to explain the occurrence of terminal fusion in combination with heterozygosity.

\section{Systematics of oribatid mites}

Mites belong to the Arthropoda and represent the most diverse and extant ancient lineage of the Chelicerata (Walter and Proctor 1999). The major taxa are Opilioacariformes, Parasitiformes (with Mesostigmata, Holothyrida and Ixodida) and Acariformes (including Sarcoptiformes, Trombidiformes and Endeostigmata) (Walter and Proctor 1999). Oribatid mites belong to the Sarcoptiformes and are classified into six groups according to morphological characters: the species-poor and basal Palaeosomata (weak sclerotization), the Enarthronota (transversal line on notogaster), Parhyposomata (continuous notogaster shield), paraphyletic Mixonomata (dichoid; with separated Proterosoma and Hysterosoma), paraphyletic Desmonomata (holoid) and species-rich Circumdehiscentia = Brachypylina (spatially separated genital and anal plate in a fused ventral shield) (Walter and Proctor 1999). Molecular analyses date the origin of oribatid mites back to the Precambrian (571 \pm 37 mya) and, therefore, they may represent an early component of terrestrial food webs (Schaefer et al. 2010). 
Species-rich and exclusively parthenogenetic clades exist within the oribatid mites pointing to ancient asexuality and parthenogenetic radiations (Norton et al. 1993). This renders oribatid mites, next to bdelloid rotifers and darwinulid ostracods (which also radiated while being parthenogenetic) so called "evolutionary scandals" (Maynard Smith 1978). Parthenogenetic reproduction should result in evolutionary short-lived lineages and is assumed to be an evolutionary dead end (Maynard Smith 1978) due to the accumulation of deleterious mutations (Muller 1964, Kondrashov 1993) and/or a reduced adaptative potential to changing environments (Ghiselin 1974, Bell 1982).

\section{Oribatid mites as model organisms}

Oribatid mites are a suitable model organism for investigations of evolutionary processes (Norton and Palmer 1991, Schaefer et al. 2006, Domes et al. 2007a, Heethoff et al. 2009), but also for studying ecological aspects of parthenogenesis. Parthenogenetic and sexual oribatid mites coexist with different frequencies in a wide range of habitats. Parthenogenetic taxa, such as Brachychthoniidae, Oppiella nova and Tectocepheus spp., dominate in new or disclimax habitats (Norton and Palmer 1991), but occur in lower proportions also in climax habitats (Maraun and Scheu 2000). The proportion of parthenogenetic individuals, e.g., in Eulohmanniidae, Brachychthoniidae, Oppiidae and certain Epilohmanniidae, increases with increasing soil depth (Luxton 1982, Norton and Palmer 1991). Fresh water habitats are inhabited by parthenogenetic species, such as of Thrypochthoniidae; Malaconothridae, Limnozetidae and certain Hydrozetes spp. (Norton and Palmer 1991). Marine habitats are mainly inhabited by sexual species (Schuster 1979), such as Ameronothrus spp. and Halozetes spp. (Proches and Marshall 2001).

Oribatid mites primarily live in soils, but also on the bark of trees. In forest soils of the temperate zone they comprise of $58 \%$ to $87 \%$ parthenogenetic individuals (Maraun et al. 2003, Fischer et al. 2010a), while on the bark of tree trunks only $1-15 \%$ of oribatid mites belong to parthenogenetic species (Erdmann et al. 2006, Fischer et al. 2010a). The proportion of parthenogenetic individuals fundamentally changes in a range of a few centimeters between forest soil and tree trunk. Investigating these patterns and indentifying the basic ecological factors and mechanisms which are responsible for the distribution of parthenogenetic and sexual oribatid mites is a promising approach to start solving the mystery of ecological advantages of sexual and parthenogenetic reproduction. 


\section{Theories about the maintenance of sexual reproduction}

In the last decades more than 25 hypotheses were developed trying to identify major factors which explain the dominance of sexual reproduction in animal taxa (Kondrashov 1993, Schoen 2009). These theories differ with regard to the key factors triggering sexual reproduction, e.g., temporal or spatial variation, resource availability or parasitism rate, short- or long-term advantages (West et al. 1999, Scheu and Drossel 2007) and explain only parts of the ecological distribution of parthenogenetic reproducing organisms. Maynard Smith (1976) wrote "one is left with the feeling that some essential feature of the situation is being overlooked".

The two most common hypotheses are the 'Tangled Bank' and the 'Red Queen'. The focus of the 'Tangled Bank theory' is a spatially heterogeneous environment in which the brake-up of locally favorable gene-combinations reduces sib-competition and may be advantageous for a better exploitation of resources in enclosed habitats (Williams 1975, Bell 1982). The 'Red Queen theory' focuses, in contrast to the 'Tangled Bank theory', on a temporally heterogeneous environment. Predators and parasites are adapted to prey on genotypes with highest frequencies. Sexual species produce genetically variable offspring which may be resistant against parasites or which may avoid or escape from predators (Glesener 1979, Hamilton 1980, Stearns 1985).

Scheu and Drossel (2007) developed a model on the maintenance of sexual reproduction, integrating spatially and temporally variation - the 'Structured Resource Theory of Sexual Reproduction' (SRTS). The fundamental assumption of the SRTS is the availability of limited amounts of resources for a population with a limited number of genotypes consuming only part of these resources Thereby depleting this fraction of the resources available for the next generation. Sexual offspring can better exploit underutilized resources and outcompete asexual ones. The model differentiates explicitly between (a) biotic and abiotic densitydependent factors and (b) physicochemical density-independent factors. These assumptions lead to predominance of asexual reproduction (1) in habitats with an excess of resources (no adaptation to limited resources needed) (2) in habitats with a small number of resources (3) in populations with a high number of genotypes which are able to exploit all possible resources to the same extent or (4) in habitats with strong density-independent effects, such as harsh, disturbed or novel environments (effects are unpredictable, individuals cannot adapt to these effects; resources are never fully exploited (Scheu and Drossel 2007)). 


\section{Overview}

This study consists of two main parts. The first part introduces the ecology of oribatid mites (Chapter $\mathbf{2}$ and $\mathbf{3}$ ) and presents data on trophic ecology and ecological factors which structure oribatid mite communities in temperate forest soils. In the second part (Chapter 4 and 5) oribatid mites were used as model organisms to test the predictions of the SRTS on the distribution of parthenogenetic individuals in below- and aboveground habitats.

The oribatid mite diversity in forest soils is high; disentangling feeding niches may help to explain this phenomenon. Furthermore, availability of food resources is the basic feature in the SRTS of Scheu and Drossel (2007) and raises the question what kind of food resources oribatid mites consume. The investigation of trophic and feeding ecology of oribatid mites is challenging since they are tiny and the opaqueness of their habitat makes direct observations difficult. In the last years considerable progress has been made using the method of stable isotope analysis allowing novel insights into the trophic ecology of oribatid mites. Chapter 2 reviews the trophic ecology of oribatid mites using the method of stable isotopes, summarizes previous results, gives perspectives for future studies and presents new data on the trophic structure of oribatid mite communities in forest soils for 26 species, compared with stable isotope data of 7 oribatid mite species from tree trunks (tree trunk data from Fischer et al. 2010a). Oribatid mites in soil span three to four trophic levels and differ in their $\delta^{15} \mathrm{~N}$ values compared to bark-living oribatid mites indicating feeding-niche differentiation in soil and between habitats. The additional analysis of $\delta^{13} \mathrm{C}$ provided additional informations on trophic niches. Taxa with endophagous juveniles were recognizable from other oribatid mites by enriched $\delta^{13} \mathrm{C}$ values. Lichens and oribatid mites diverged strong in their $\delta^{13} \mathrm{C}$ values and showed that bark-living oribatid mites feed mainly on lichens and not on mosses.

In Chapter 3 the importance of biotic and abiotic environmental factors and their influence on density, diversity and the structure of oribatid mite communities in coniferous forests (Picea abies or Pinus sylvestris; depending on the study site); beech forests (Fagus sylvatica; 30 $\mathrm{y}$ and $70 \mathrm{y}$ old) and unmanaged beech forests was studied. The four forest types were replicated in three regions in Germany, spanning a latitudinal gradient of $\sim 500 \mathrm{~km}$. The study design allowed general conclusions on structuring factors for oribatid mite density, diversity and community composition in the four forest types. The investigated tree species and management types are most common and typical for Central Europe. We suspected highest densities in coniferous forests due to thick litter layer and highest diversity in old unmanaged forests due to increased habitat heterogeneity. Oribatid mite densities decrease from coniferous over $30 \mathrm{y}$ and $70 \mathrm{y}$ old beech forests to the unmanaged beech forests and were 
correlated positively with the mass of litter layer and negatively with soil $\mathrm{pH}$. Diversity of oribatid mites was little affected by forest type indicating that they harbor similar numbers of niches. The oribatid mite community structure differed more between the three regions than between the four forest types indicating the importance of regional factors rather than factors associated with forest types. Soil $\mathrm{pH}$, which is a factor resulting from regional geological conditions and local forest types, strongly affected the oribatid mite communities.

In Chapter 4 one prediction of the SRTS was tested for soil-living oribatid mites. Habitats with an excess of resources should be dominated by asexual organisms because adaptation to limited resources is not needed. That means, the proportion of parthenogenetic oribatid mites should increase with increasing availability of resources. The amount of food resources was estimated indirectly since food sources of oribatid mites are only partially known and their amount in soil is hardly detectable. Increased densities and respiration values of oribatid mites per square meter were assumed to indicate increased resource availability. An increase in the proportion of parthenogenetic oribatid mites with increasing densities or respiration of oribatid mites per square meter would support the assumption of the SRTS. The correlation of the proportion of parthenogenetic oribatid mites with densities or respiration of oribatid mites per square meter was tested and compared on the small scale (two regions in Germany: Schorfheide and Swabian Alb), as well as on the large scale (worldwide) in a meta analysis. The assumption of the SRTS was supported in the small scale and in the large scale analysis. Overall, oribatid mite densities correlated positively with the proportion of parthenogenetic individuals. Locally, the density and respiration of oribatid mites correlated significantly with the proportion of parthenogenetic individuals in Schorfheide, but not in the Swabian Alb. High densities of earthworms in the Swabian Alb may superimpose the effects of food-resources on oribatid mites compared with Schorfheide with low earthworm densities.

The effect of resource availability on oribatid mite densities and on the proportion of parthenogenetic individuals was investigated on the bark of tree trunks in Chapter 5. One prediction of the SRTS is the prevalence of parthenogenesis in habitats with strong densityindependent effects, such as harsh, disturbed or novel environments (Scheu and Drossel 2007). The bark of tree trunks is considered as harsh environment affected by desiccation, frost and solar radiation. In contrast to those theoretical expectations, the bark of tree trunks is dominated by sexual oribatid mite species (Erdmann et al. 2006, Fischer et al. 2010a). The SRTS states that sexual reproduction should dominate in habitats where resources are limited or little accessibly. The resource availability on tree trunks was manipulated by monthly fertilization of bark with nitrogen (N), carbon (C), both ( $\mathrm{N}$ and $\mathrm{C}$ ) and water as control. An increase of oribatid mite densities and in the proportion of parthenogenetic individuals due to 
fertilization would indicate resource limitation rather than limitation by harsh abiotic conditions as predicted by the SRTS. The uptake of fertilizers by oribatid mites was evaluated using stable isotopes $\left({ }^{14} \mathrm{~N} /{ }^{15} \mathrm{~N} ;{ }^{12} \mathrm{C} /{ }^{13} \mathrm{C}\right)$. Oribatid mite densities increased in treatments with $\mathrm{C}$ fertilization. The fertilization with $\mathrm{N}$ had no effect. This is in accordance with stable isotope data indicating the incorporation of $\mathrm{C}$ but not of $\mathrm{N}$ of the fertilizers in the tissue of oribatid mites. The increase in oribatid mite densities due to $C$ fertilization indicates food resource limitation on bark and supports the suggestions made by the SRTS.

All studies were conducted in the framework of the Biodiversity Exploratories (www.Biodiversity-Exploratories.de), a long-term and large-scale project investigating forest and grassland sites, established in three regions in Germany (the Swabian Alb, the Hainich and the Schorfheide-Chorin). The aim of the Biodiversity Exploratories is the investigation of the role of land use and management on biodiversity, ecosystem functions and services (Fischer et al. 2010b) 


\section{References}

Anderson, J.M. (1975) The enigma of soil animal species diversity. In: Vanek, J., (ed.), Progress In Soil Zoology, pp. 51-58. Academia, Prague.

Aoki, J. (1967) Microhabitats of oribatid mites on a forest floor. Bulletin of the National Science Museum 10, 133-138.

Bell, G. (1982) The Masterpiece of Nature: The Evolution and Genetics of Sexuality. University of California Press, Berkeley.

Caruso, T., Taormina, M., Migliorini, M. (2011) Relative role of deterministic and stochastic determinants of soil animal community: a spatially explicit analysis of oribatid mites. Journal of Animal Ecology 81, 214-221.

Cianciolo, J.M., Norton, R.A. (2006) The ecological distribution of reproductive mode in oribatid mites as related to biological complexity. Experimental \& Applied Acarology 40, 1-25.

Domes, K., Norton, R.A., Maraun, M., Scheu, S. (2007a) Reevolution of sexuality breaks Dollo's law. Proceedings of the National Academy of Sciences of the United States of America 104, 71397144.

Domes, K., Scheu, S., Maraun, M. (2007b) Resources and sex: Soil re-colonization by sexual and parthenogenetic oribatid mites. Pedobiologia 51, 1-11.

Eisenhauer, N. (2010) The action of an animal ecosystem engineer: Identification of the main mechanisms of earthworm impacts on soil microarthropods. Pedobiologia 53, 343-352.

Erdmann, G., Floren, A., Linsenmair, K.E., Scheu, S., Maraun, M. (2006) Little effect of forest age on oribatid mites on the bark of trees. Pedobiologia 50, 433-441.

Erdmann, G., Otte, V., Langel, R., Scheu, S., Maraun, M. (2007) The trophic structure of bark-living oribatid mite communities analyzed with stable isotopes $\left({ }^{15} \mathrm{~N},{ }^{13} \mathrm{C}\right)$ indicates strong niche differentiation. Experimental \& Applied Acarology 41, 1-10.

Fischer, B.M., Schatz, H., Maraun, M. (2010a) Community structure, trophic position and reproductive mode of soil and bark-living oribatid mites in an alpine grassland ecosystem. Experimental \& Applied Acarology 52, 221-237.

Fischer, M., Bossdorf, O., Gockel, S., Haensel, F., Hemp, A., Hessenmoeller, D., Korte, G., Nieschulze, J., Pfeiffer, S., Prati, D., Renner, S., Schoening, I., Schumacher, U., Wells, K., Buscot, F., Kalko, E.K.V., Linsenmair, K.E., Schulze, E.D., Weisser, W.W. (2010b) Implementing large-scale and long-term functional biodiversity research: The Biodiversity Exploratories. Basic and Applied Ecology 11, 473-485.

Ghiselin, M.T. (1974) The Economy of Nature and the Evolution of Sex. University of California Press, Berkeley.

Giller, P.S. (1996) The diversity of soil communities the 'poor man's tropical rainforest'. Biodiversity and Conservation 5, 135-168.

Gjelstrup, P., Sochting, U. (1979) Cryptostigmatic mites (Acarina) associated with Ramalina siliquosa (Lichenes) on Bornholm in the Baltic. Pedobiologia 19, 237-245.

Glesener, R.R. (1979) Recombination in a simulated predator-prey interaction. American Zoologist $19,763-771$.

Grandjean, F. (1941) Statistique sexuelle et parthénogenèse chez les Qribates (Acariens). Comptes Rendus Academie Sciencés 212, 463-467.

Grandjean, F. (1950) Observations éthologiques sur Camisia segnis (Herm.) et Platynothrus peltifer (Koch). Bulletin du Museum National d'Histoire Naturelle 22, 224-231. 
Grandjean, F. (1955) Caractère chitineux de l'ovipositeur, en structure normale, chez les oribates (Acariens). Archive de Zoologie Expérimentale et Générale 93, 96-106.

Grandjean, F. (1956) Observations sur les Oribates. Bulletin du Museum National d'Histoire Naturelle 28, 205-212.

Hamilton, W.D. (1980) Sex versus non-sex versus parasite. Oikos 35, 282-290.

Heethoff, M., Bergmann, P., Norton, R.A. (2006) Karyology and sex determination of oribatid mites. Acarologia 46, 127-131.

Heethoff, M., Norton, R.A., Scheu, S., Maraun, M. (2009) Parthenogenesis in Oribatid Mites (Acari, Oribatida): Evolution Without Sex. In: Schoen, I., Martens, K., Dijk, P. (eds.), Lost Sex: The Evolutionary Biology of Parthenogenesis, pp. 241-258. Springer, Dordrecht.

Heethoff, M., Koerner, L., Norton, R.A., Raspotnig, G. (2011) Tasty but protected: first evidence of chemical defense in oribatid mites. Journal of Chemical Ecology 37, 1037-1043.

Heidemann, K., Scheu, S., Ruess, L., Maraun, M. (2011) Molecular detection of nematode predation and scavenging in oribatid mites: laboratory and field experiments. Soil Biology \& Biochemistry $43,2229-2236$.

Hubert, J., Zilova, M., Pekar, S. (2001) Feeding preferences and gut contents of three panphytophagous oribatid mites (Acari: Oribatida). European Journal of Soil Biology 37, 197208.

Kaneko, N. (1988) Feeding habits and cheliceral size of oribatid mites in cool temperate forest soils in Japan. Revue d'Écologie et de Biologie du Sol 25, 353-363.

Kondrashov, A.S. (1993) Classification of hypotheses on the advantage of amphimixis. Journal of Heredity 84, 372-387.

Koukol, O., Mourek, J., Janovsky, Z., Cerna, K. (2009) Do oribatid mites (Acari: Oribatida) show a higher preference for ubiquitous vs. specialized saprotrophic fungi from pine litter? Soil Biology \& Biochemistry 41, 1124-1131.

Krantz, G.W. (2009) Form and Function. In: Krantz, G.W., Walter, D.E. (eds.), A Manual of Acarology, 3rd edition, pp. 124-232. Texas Tech University Press, Lubbock.

Lebrun, P. (1970) Écologie et biologie de Nothrus palustris (C.L. Koch 1839). (Acarien, Oribate). IV. Survivance-fécondité-action d'un prédateur. Acarologia 12, 827-848.

Lenoir, L., Persson, T., Bengtsson, J., Wallander, H., Wiren, A. (2007) Bottom-up or top-down control in forest soil microcosms? Effects of soil fauna on fungal biomass and $\mathrm{C} / \mathrm{N}$ mineralization. Biology and Fertility of Soils 43, 281-294.

Lindo, Z., Winchester, N. (2007) Oribatid mite communities and foliar litter decomposition in canopy suspended soils and forest floor habitats of western redcedar forests, Vancouver Islands, Canada. Soil Biology \& Biochemistry 39, 2957-2966.

Lussenhop, J. (1992) Mechanisms of microarthropod-microbial interactions in soil. In: Begon, M., Fitter, A.H. (eds.), Ecological Research, Vol. 23, pp. 1-33. Academic Press, London.

Luxton, M. (1981) Studies on the oribatid mites of a Danish beech wood soil VI. Developmental biology. Pedobiologia 21, 312-340.

Luxton, M. (1982) The biology of mites from a woodland soil. Pedobiologia 23, 1-8.

Maraun, M., Visser, S., Scheu, S. (1998) Oribatid mites enhance the recovery of the microbial community after strong disturbance. Applied Soil Ecology 9, 175-181.

Maraun, M., Scheu, S. (2000) The structure of oribatid mite communities (Acari, Oribatida): patterns, mechanisms and implications for future research. Ecography 23, 374-383. 
Maraun, M., Salamon, J.A., Schneider, K., Schaefer, M., Scheu, S. (2003) Oribatid mite and collembolan diversity, density and community structure in a moder beech forest (Fagus sylvatica): effects of mechanical perturbations. Soil Biology \& Biochemistry 35, 1387-1394.

Maraun, M., Schatz, H., Scheu, S. (2007) Awesome or ordinary? Global diversity patterns of mites. Ecography 30, 209-216.

Maynard Smith, J. (1976) A short-term advantage of sex and recombination through sibcompetition. Journal of Theoretical Biology 63, 245-258.

Maynard Smith, J. (1978) The Evolution of Sex. Cambridge University Press, Cambridge.

Migge-Kleian, S., Mclean, M.A., Maerz, J.C., Heneghan, L. (2006) The influence of invasive earthworms on indigenous fauna in ecosystems previously uninhabited by earthworms. Biological Invasions 8, 1275-1285.

Muller, H. J. (1964) The relation of recombination to mutational advance. Mutation Research 1, 2-9.

Norton, R.A., MacNamara, M.C. (1976) The common newt (Notophthalmus viridescens) as a predator of soil mites in New York. Journal of the Entomological Society Georgia 11, 89-93.

Norton, R.A., Palmer, S.C. (1991) The distribution, mechanisms and evolutionary significance of parthenogenesis in oribatid mites. In: Schuster, R., Murphy, P.W. (eds.), The Acari. Reproduction, Development and Life History Strategies, pp. 107-136. Chapman and Hall, London.

Norton, R.A., Kethley, J.B., Johnston, D.E., O'Connor, B.M. (1993) Phylogenetic perspectives on genetic systems and reproductive modes of mites. In: Wrensch, D.L., Ebbert, M.A. (eds.), Evolution and Diversity of Sex Ratios, pp. 8-99. Chapman and Hall, New York.

Norton, R.A. (1994) Evolutionary aspects of oribatid mite life histories and consequences for the origin of the Astigmata. In: Houck, M. (ed.), Mites. Ecological and Evolutionary Analyses of LifeHistory Patterns, pp. 99-135. Chapman and Hall, New York.

Norton, R.A., Behan-Pelletier, V. (2009) Suborder Oribatida. In: Krantz, G.W., Walter, D.E. (eds.), A Manual of Acarology, 3rd edition, pp. 430-564. Texas Tech University Press, Texas.

Palmer, S.C., Norton, R.A. (1992) Genetic diversity in thelytokous oribatid mites (Acari, Acariformes, Desmonomata). Biochemical Systematics and Ecology 20, 219-231.

Peschel, K., Norton, R.A., Scheu, S., Maraun, M. (2006) Do oribatid mites live in enemy-free space? Evidence from feeding experiments with the predatory mite Pergamasus septentrionalis. Soil Biology \& Biochemistry 38, 2985-2989.

Pollierer, M.M., Langel, R., Koerner, C., Maraun, M., Scheu, S. (2007) The underestimated importance of belowground carbon input for forest soil animal food webs. Ecology Letters 10, 729-736.

Proches, S., Marshall, D.J. (2001) Global distribution patterns of non-halacarid marine intertidal mites: implications for their origins in marine habitats. Journal of Biogeography 28, 47-58.

Renker, C., Otto, P., Schneider, K., Zimdars, B., Maraun, M., Buscot, F. (2005) Oribatid mites as potential vectors for soil microfungi: Study of mite-associated fungal species. Microbial Ecology $50,518-528$.

Saichuae, P., Gerson, U., Henis, Y. (1972) Observations on feeding and life history of the mite Nothrus biciliatus (Koch). Soil Biology \& Biochemistry 4, 155-164.

Salamon, J., Alphei, J., Ruf, A., Schaefer, M., Scheu, S., Schneider, K., Suehrig, A., Maraun, M. (2006) Transitory dynamic effects in the soil invertebrate community in a temperate deciduous forest: Effects of resource quality. Soil Biology \& Biochemistry 38, 209-221.

Saporito, R.A., Donnelly, M.A., Norton, R.A., Garraffo, H.M., Spande, T.F., Daly, J.W. (2007) Oribatid mites as a major dietary source for alkaloids in poison frogs. Proceedings of the National Academy of Sciences of the United States of America 104, 8885-8890. 
Schaefer, I., Domes, K., Heethoff, M., Schneider, K., Schoen, I., Norton, R.A., Scheu, S., Maraun, M. (2006) No evidence for the ,Meselson effect' in parthenogenetic oribatid mites (Oribatida, Acari). Journal of Evolutionary Biology 19, 184-193.

Schaefer, I., Norton, R.A., Scheu, S., Maraun, M. (2010) Arthropod colonization of land - Linking molecules and fossils in oribatid mites (Acari, Oribatida). Molecular Phylogenetics and Evolution $57,113-121$.

Schatz, H. (2005) Diversity and global distribution of oribatid mites - evaluation of the present state of knowledge. Phytophaga 14, 485-500.

Scheu, S., Drossel, B. (2007) Sexual reproduction prevails in a world of structured resources in short supply. Proceedings of the Royal Society B - Biological Sciences 274, 1225-1231.

Schneider, K., Migge, S., Norton, R.A., Scheu, S., Langel, R., Reineking, A., Maraun, M. (2004) Trophic niche differentiation in soil microarthropods (Oribatida, Acari): evidence from stable isotope ratios $\left({ }^{15} \mathrm{~N} /{ }^{14} \mathrm{~N}\right)$. Soil Biology \& Biochemistry 36, 1769-1774.

Schneider, K., Maraun, M. (2005) Feeding preferences among dark pigmented fungal taxa („Dematiacea“) indicate limited trophic niche differentiation of oribatid mites (Oribatida, Acari). Pedobiologia 49, 61-67.

Schneider, K., Maraun, M. (2009) Top-down control of soil microarthropods - Evidence from a laboratory experiment. Soil Biology \& Biochemistry 41, 170-175.

Schoen, I. (2009) Foreword. In: Schoen, I., Martens, K., Dijk, P. (eds.), Lost Sex: The Evolutionary Biology of Parthenogenesis, pp. v-vii. Springer, Dordrecht.

Schuster, R. (1966) Scydmaeniden-Larven als Milbenräuber. Naturwissenschaften 53, 439-440.

Schuster, R. (1979) Soil mites in the marine environment. In: Rodriguez, J.G. (ed.), Recent Advances in Acarology, Vol. I., pp. 593-602. Academic Press, New York.

Siepel, H., deReuiter-Dijkmann, E.M. (1993) Feeding guilds of oribatid mites based on their Carbohydrase activity. Soil Biology \& Biochemistry 25, 1491-1497.

Stary, J., Block, W. (1998) Distribution and biogeography of oribatid mites (Acari: Oribatida) in Antarctica, the sub-Antarctic islands and nearby land areas. Journal of Natural History 32, 861894.

Stearns, S.C. (1985) The evolution of sex and the role of sex in evolution. Experientia 41, 12311235.

Subias, L.S. (2004) Listado sistematico, sinonimico y biogeografico de los acaros oribatidos (Acariformes, Oribatida) del mundo (1758-2002). Graellsia 60, 3-305.

Taberly, G. (1987) Recherches sur la parthénogenése thélythoque de deux espéces d'acariens oribatides: Thrypochthonius tectorum (Berlese) et Platynothrus peltifer (Koch). III. Etude anatomique, histologique et cytologique des femelles parthénogenétiques. Acarologia 28, 389403.

Taberly, G. (1988) Recherches sur la parthénogenése thélythoque de deux espéces d'acariens oribatides: Thrypochthonius tectorum (Berlese) et Platynothrus peltifer (Koch). IV. Observation sur les males ataviques. Acarologia 29, 95-107.

Travé, J. (1963) Écologie et biologie des Oribates (Acariens) saxicoles et arboricoles. Vie et Milieu, Supplement 14, 1-267.

Wallwork, J.A. (1980) Desert soil microarthropods, an " $r$ "-selected system. In: Dindal, D.L. (ed.), Soil Biology As Related To Land Use Practices. Proceedings of the $7^{\text {th }}$ International Soil Colloquium, pp. 759-769. Washington.

Walter, D.E., Proctor, H.C. (1999) Mites: Ecology, Evolution and Behavior. CABI Publishing, Wallingford. 
Webb, N.R. (1989) Observations on the life cycle of Steganacarus magnus (Acari: Cryptostigmata). Pedobiologia 33, 293-299.

Weigmann, G. (2006) Die Hornmilben (Oribatida). In: Dahl, F. (ed.), Die Tierwelt Deutschlands 76, pp. 1-520. Goecke und Evers, Keltern.

West, S.A., Lively, C.N., Read, A.F. (1999) A pluralist view to sex and recombination. Journal of Evolutionary Biology 12, 1003-1012.

Williams, G.C. (1975) Sex and Evolution. Princeton University Press, Princeton.

Wilson, E.O. (2005) Oribatid mite predation by small ants of the genus Pheidole. Insectes Sociaux 52, 263-265.

Woodring, J.P., Cook, E.F. (1962) The biology of Ceratozetes cisalpinus Berl., Scheloribates laevigatus Koch, and Oppia neerlandica Oudemans with a description of all stages. Acarologia 4, 101-137.

Wrensch, D.L., Kethley, J.B., Norton, R.A. (1994) Cytogenetics of holokinetic chromosomes and inverted meiosis: Keys to the evolutionary success of mites, with generalizations on eukaryotes. In: Houck, M.A. (ed.), Mites: Ecological and Evolutionary Analyses of Life-History Patterns, pp. 282-343. Chapman and Hall, New York.

Wunderle, I. (1992) Die Oribatiden-Gemeinschaft (Acari) der verschiedenen Habitate eines Buchenwaldes. Carolinea 50, 79-144. 


\section{Author contributions}

Chapter 2: Stable isotopes revisited: Their use and limits for oribatid mite trophic ecology Authors: M. Maraun, G. Erdmann, B.M. Fischer, M.M. Pollierer, R.A. Norton, K. Schneider, S. Scheu

Published in Soil Biology \& Biochemistry (2011), Volume 43, Issue 5, Pages 877-882.

Contributions: Idea by M.M., R.A.N., S.S., K.S. \& G.E.; empirical data from G.E., B.M.F., K.S. \& M.M.P.; analysis by M.M. \& G.E.; text written by M.M., G.E., S.S. \& M.M.P.

Chapter 3: Regional factors rather than forest type drive the community structure of soil living oribatid mites (Acari, Oribatida)

Authors: G. Erdmann, S. Scheu, M. Maraun

Published in Experimental and Applied Acarology (2012), Volume 57, Issue 2, Pages 157-169.

Contributions: Idea by M.M., S.S. \& G.E.; empirical data from G.E.; analysis by G.E.; text written by G.E., S.S. \& M.M.

Chapter 4: Positive correlation between density and parthenogenetic reproduction in oribatid mites (Acari) supports the structured resource theory of sexual reproduction Authors: M. Maraun, R.A. Norton, R.B. Ehnes, S. Scheu, G. Erdmann

Published in Evolutionary Ecology Research (2012), Volume 14, Number 4, Pages 311-323.

Contributions: Idea by M.M. \& S.S.; empirical data from M.M. \& G.E.; analysis by M.M., G.E. \& R.B.E.; text written by M.M., S.S. \& G.E.

Chapter 5: Oribatid mite density (Acari, Oribatida) on tree trunks is regulated by food resources - confirming the "Structured Resource Theory of Sexual Reproduction"

Authors: G.Erdmann, S. Scheu, M. Maraun

In preparation

Contributions: Idea by M.M., S.S. \& G.E.; empirical data from G.E.; analysis by G.E. \& M.M.; text written by G.E., S.S. \& M.M. 


\section{Chapter 2}

\section{Stable isotopes revisited: Their use and limits for oribatid mite trophic ecology}

Maraun, M., Erdmann,G., Fischer, B.M., Pollierer, M.M., Norton, R.A., Schneider, K., Scheu, S.

published in:

Maraun, M., Erdmann, G., Fischer, B.M., Pollierer, M.M., Norton, R.A., Schneider, K., Scheu, S.

(2011) Stable isotopes revisited: Their use and limits for oribatid mite trophic ecology. Soil Biology \& Biochemistry, 43, 877-882. 


\section{Abstract}

In this review we summarize our knowledge of using stable isotopes $\left({ }^{15} \mathrm{~N} /{ }^{14} \mathrm{~N},{ }^{13} \mathrm{C} /{ }^{12} \mathrm{C}\right)$ to better understand the trophic ecology of oribatid mites. Our aim is to (a) recapitulate the history of stable isotope research in soil animals with a focus on oribatid mites, (b) present new stable isotope data for oribatid mites and the current state knowledge of oribatid mite trophic niche differentiation, (c) compile problems and limitations of stable isotope based analyses of trophic relationships and (d) suggest future challenges, questions and problems that may be solved using stable isotope analyses and other novel techniques for improving our understanding on the trophic ecology of soil invertebrates. We conclude that (1) in addition to ${ }^{15} \mathrm{~N} /{ }^{14} \mathrm{~N}$ ratios, ${ }^{13} \mathrm{C} /{ }^{12} \mathrm{C}$ ratios contribute to our understanding of the trophic ecology of oribatid mites, allowing e.g., separation of lichen- and moss-feeding species, (2) there likely are many lichen but few moss feeding oribatid mite species, (3) oribatid mite species that are endophagous as juveniles are separated by their stable isotope signatures from all other oribatid mite species, (4) fungivorous oribatid mite species cannot be separated further, e.g., the fungal taxa they feed on cannot be delineated. A particular problem in using stable isotope data is the difficulty in determining signatures for basal food resources since decomposing material, fungi and lichens comprise various components differing in stable isotope signatures; ${ }^{13} \mathrm{C} /{ }^{12} \mathrm{C}$ ratios and potentially other isotopes may help in identifying the role of these resources for decomposer animal nutrition.

\section{The history of the use of stable isotopes in soil food web analysis}

Terrestrial soil ecologists came rather late to the use of stable isotope ratios (mainly ${ }^{15} \mathrm{~N} /{ }^{14} \mathrm{~N}$ and ${ }^{13} \mathrm{C} /{ }^{12} \mathrm{C}$ ) to analyze the structure of food webs. When we started with our now frequentlycited study about stable isotope ratios $\left({ }^{15} \mathrm{~N} /{ }^{14} \mathrm{~N}\right)$ in soil-living oribatid mites (Schneider et al. 2004 ) in 2003 , stable isotopes had been used for decades to study trophic relationships in marine (Minagawa and Wada 1984, Sholto-Douglas et al. 1991) and freshwater systems (Gu et al. 1994, Hall 1995). In soil systems the seminal papers by Ponsard and Arditi (2000) and Scheu and Falca (2000) used stable isotopes $\left({ }^{15} \mathrm{~N} /{ }^{14} \mathrm{~N}\right.$ and $\left.{ }^{13} \mathrm{C} /{ }^{12} \mathrm{C}\right)$ for the first time to analyze the trophic structure of soil animal food webs in a comprehensive way. The results of these two studies indicated that food chains in soil are rather short, with decomposers being clearly separated from predators, but they suggested strong variation in the trophic position of species of both decomposers and predators. 
Stable isotopes have been used not only to study trophic levels in food webs but also to investigate the trophic ecology of specific taxonomic groups, e.g., earthworms (Martin et al. 1992), seabirds (Hobson et al. 1994), pinnipeds (Hobson et al. 1997), amphibians (Altig et al. 2007) and lizards (Struck et al. 2002). Their application to soil animals started in the 1980s with the investigation of termites (Boutton 1983, Tayasu 1998) and was continued by studies on ants (Blüthgen et al. 2003) and earthworms (Schmidt and Ostle 1999). The results indicated marked trophic niche separation of the respective species. It was not until 2004 that stable isotopes were used to delineate trophic niches of a major group of putatively saprophagous soil mesofauna, the oribatid mites (Schneider et al. 2004), and one year later this study was followed by a similar investigation of Collembola (Chahartaghi et al. 2005). A third study focusing on the predatory soil mesofauna, i.e. mesostigmate (gamasid) mites, is pending (B. Klarner, unpublished data).

Only nine species of oribatid mites were included in the stable isotope study of Scheu and Falca (2000) and none in that of Ponsard and Arditi (2000). Therefore, in Schneider et al. (2004) we chose to investigate the stable isotope ratios $\left({ }^{15} \mathrm{~N} /{ }^{14} \mathrm{~N}\right)$ of oribatid mite species of forests in a comprehensive way, by including all major taxa and comparing different forests. Further, for investigating variations in stable isotope ratios between habitats and between developmental stages we included oribatid mites from different microhabitats, e.g.,, the bark of trees, and analyzed both adults and juveniles of some species. For delineating the baseline, potential food resources of decomposer species were investigated.

The use of stable isotopes for studying food webs was introduced by DeNiro and Epstein (1981), Minagawa and Wada (1984) and Wada et al. (1991). They found that the trophic structure of animal communities can be evaluated by analyzing the natural variation in ${ }^{15} \mathrm{~N} /{ }^{14} \mathrm{~N}$ and ${ }^{13} \mathrm{C} /{ }^{12} \mathrm{C}$ ratios. On average, animal tissues are enriched in ${ }^{15} \mathrm{~N}$ compared with their food source by about of $3.4 \delta$ units per trophic level and in ${ }^{13} \mathrm{C}$ by about $1 \delta$ unit (Post 2002). This allows fast and standardized evaluation of the trophic structure of animal food webs even if little is known of predator - prey relationships. This is particularly advantageous for analyzing food web structure of cryptic communities like those in soil. Stable isotope analysis is particularly powerful in opening the structure of soil animal food webs if combined with other recently developed methods for analyzing food webs, such as fatty acid analysis (Chamberlain et al. 2004, Ruess et al. 2004, 2005a) and molecular gut content analysis (King et al. 2008), as these methods allow closer identification of trophic links. Similar to fatty acid analysis, but in contrast to molecular gut content analysis, stable isotope ratios of animal tissue reflect nutrition over long periods of time, allowing the delineation of general characteristics of the 
trophic structure of food webs. Further, variations in ${ }^{13} \mathrm{C} /{ }^{12} \mathrm{C}$ ratios of food resources, e.g., between C3 and C4 plants, allow us to trace the transfer of carbon from major resources through animal food webs (Oelbermann et al. 2008, Pringle and Fox-Dobbs 2008).

\section{Uncovering the trophic structure of oribatid mite communities}

The analysis of the stable isotope ratios of nitrogen $\left({ }^{15} \mathrm{~N} /{ }^{14} \mathrm{~N}\right)$ and carbon $\left({ }^{13} \mathrm{C} /{ }^{12} \mathrm{C}\right)$ has contributed significantly to our understanding of the trophic structure of soil animal taxa and this started with the detailed analysis of oribatid mites (Schneider et al. 2004). First and most important, this study showed that stable isotope ratios of nitrogen in this single taxonomic group of soil invertebrates vary to an extent that was entirely unexpected. In fact, the results indicated that oribatid mites span about four trophic levels, similar to what had been suggested previously for the total invertebrate soil animal food web of deciduous forests (Scheu and Falca 2000). This is highly incongruent with the common practice of lumping oribatid mites into a single trophic group and indicates that soil food webs based on such coarse taxonomic units lack realism and represent caricatures of nature.

Early studies based on physical gut content analyses and direct observation had already suggested that "mycophagous" soil invertebrates like oribatid mites in fact are trophically diverse and include species living as predators, scavengers, algal and lichen feeders (e.g., Walter 1987), but the findings remained somewhat anecdotal and were largely ignored. Using stable isotope analysis, and analyzing a wide range of oribatid mite species living in the same habitat, the study of Schneider et al. (2004) confirmed these observations and thereby received considerable attention. Based on oribatid mites sampled in different forests the study brought realism into previously scattered investigations of the feeding mode of decomposer soil mesofauna. Much previous knowledge derived from laboratory observations of species kept under artificial conditions and offered food materials without choice. For example, mites of the genus Hypochthonius were shown to consume fungi (Maraun et al. 1998) and algae (Norton and Behan-Pelletier 2009), but also living and dead animals, i.e. they can function as predators or necrophages (Riha 1951). High ${ }^{15} \mathrm{~N} /{ }^{14} \mathrm{~N}$ ratios of Hypochthonius rufulus in the study of Schneider et al. (2004) suggest that this species in fact predominantly lives on an animal diet, presumably nematodes or other small and slow moving soil invertebrates which these rather slow moving mites are able to catch, or on their dead remains. Similarly, stable isotope analyses support early assumptions of the diet of the bark-living species Mycobates parmeliae, which was been named after lichens of the genus Parmelia in which it is often 
found. Lichens are characterized by very specific stable isotope signatures (low ${ }^{15} \mathrm{~N} /{ }^{14} \mathrm{~N}$ and high ${ }^{13} \mathrm{C} /{ }^{12} \mathrm{C}$ ratios), which separate lichens from most other food resources (Fischer et al. 2010); therefore, oribatid mite species with signatures close to the lichens in which they live are likely to also feed on them.

One of the remarkable findings of Schneider et al. (2004) was that a given oribatid mite species appears to occupy a very similar trophic niche even if living in rather different forests. Earlier findings based on stable isotope ratios suggested that trophic niches of soil invertebrates also differ little with soil depth (Scheu and Falca 2000). Further, Schneider et al. (2004) found little difference between signatures of adult and juvenile oribatid mite species, suggesting that trophic niches change little during ontogeny. Overall, these results point to a remarkable constancy of trophic niches in oribatid mites and presumably also other soil mesofauna, such as Collembola (Chahartaghi et al. 2005). Constancy and discreteness of trophic niches is particularly surprising considering the wide range of food materials of decomposer soil invertebrates, such as oribatid mites and Collembola, consume if offered in the laboratory (Ruess et al. 2005a). The similarity of a species' stable isotope signature in different habitats (calibrated to stable isotope ratios of the predominant litter material) and in different studies further indicates that trophic niches vary little over time. Temporal constancy also is surprising as litter materials enter the decomposer system in a pulsed way - particularly in temperate forest ecosystems - and are colonized and broken down by a succession of different fungal species (Hudson 1968, Hayes 1979, Osono 2007). However, detailed data on temporal changes in stable isotope signatures in soil animal species remains scarce, so general conclusions on changes in trophic niches in time and space are difficult to draw. Also, the conclusion that trophic niches of oribatid mite species change little during ontogeny may be premature and needs further investigation. Generally, little is known about differences in feeding habits between juveniles and adults in oribatid mites and other soil invertebrates; stable isotope analyses may be particularly helpful in elucidating if marked changes in morphology in phylogenetically derived species - such as brachypyline oribatid mites - are associated with shifts in diets.

Recent analyses of stable isotope signatures of bark-living oribatid mites (Erdmann et al. 2007) support the conclusion of Schneider et al. (2004) that individual species occupy distinct trophic niches. However, as with soil species, the exact food materials of bark-living species remains unclear; their stable isotope ratios do not match the signatures of potential food resources analyzed so far, indicating that they feed on cryptic resources, potentially algae or filamentous fungi that decompose bark residues. Surprisingly, we could not ascribe a single 
oribatid mite species to moss-feeding despite their collective common name, "moss mites". Mosses are characterized by low ${ }^{13} \mathrm{C} /{ }^{12} \mathrm{C}$ and ${ }^{15} \mathrm{~N} /{ }^{14} \mathrm{~N}$ ratios (Bokhorst et al. 2007, Fischer et al. 2010), which should allow identification of their consumers.

\section{Recent progress}

In Figure 1 we summarize recently obtained stable isotope data $\left({ }^{15} \mathrm{~N} /{ }^{14} \mathrm{~N} ;{ }^{13} \mathrm{C} /{ }^{12} \mathrm{C}\right)$ from the bark of trees (Fischer et al. 2010) and from soil (G. Erdmann, unpublished data). Compilation of data from different habitats needs calibration as stable isotope ratios of primary producers may differ. We calibrated the data based on members of the genus Ceratozetes that occurred in both habitats; i.e. Ceratozetes gracilis from soil in the Hainich = Ceratozetes minutissimus from bark in Austria (in the figure only $C$. gracilis is indicated) since no species simultaneously occurred on the bark of trees and in soil. Using such a calibration the stable isotope data of the soil living oribatid mite species remained unchanged whereas the signatures of the bark living species were slightly changed. The $\delta^{15} \mathrm{~N}$ values of bark itself and of oribatid mites from the bark are much lower than those from litter and soil, which agrees with Schneider et al. (2004) and Heethoff et al. (2009).

The combined analysis of ${ }^{15} \mathrm{~N} /{ }^{14} \mathrm{~N}$ and ${ }^{13} \mathrm{C} /{ }^{12} \mathrm{C}$ ratios of oribatid mites indicates that both are useful in delineating the structure of soil and bark food webs and the identification of food resources of oribatid mites. Since ${ }^{13} \mathrm{C}$ is only little enriched in consumers (Wada and Minagawa 1984, Post 2002, Martinez del Rio et al. 2009), it has been dismissed as a useful indicator of the trophic structure of soil communities (Ponsard and Arditi 2000). However, as indicated by our compilation of data (Fig. 1) and others (Schmidt et al. 2004, Tiunov 2007), $\delta^{13} \mathrm{C}$ values in fact may be a valuable tool to disentangle the trophic structure of soil and bark living invertebrates. In combination with $\delta^{15} \mathrm{~N}$ values this suggests that the differences in the species composition of arthropods living on bark and in soil correlate with differences in food resources. Further, as documented recently, $\delta^{13} \mathrm{C}$ values of decomposer animals may allow us to disentangle the components of the litter material that detritivorous animals actually feed on (Pollierer et al. 2009). Also, the combined analysis of $\delta^{15} \mathrm{~N}$ and $\delta^{13} \mathrm{C}$ values may help us to distinguish organisms feeding on saprotrophic fungi from those feeding on ectomycorrhizal fungi since ectomycorrhizal fungi are enriched in ${ }^{15} \mathrm{~N}$ and depleted in ${ }^{13} \mathrm{C}$, compared to saprophages (Hobbie et al. 2007, 2009). 
$\delta^{13} \mathrm{C}$ values of oribatid mites have also presented surprises. Some oribatid mites, mainly in the Ptyctima but also in a few other taxa, such as the brachypyline genera Carabodes and Liacarus, are enriched in ${ }^{13} \mathrm{C}$ (Fig. 1). It is known that Ptyctima and Carabodes species incorporate calcium carbonate to harden their exoskeleton (Norton and Behan-Pelletier 1991) and this probably is reflected in their ${ }^{13} \mathrm{C}$ signature. Presumably, these species use $\mathrm{CO}_{2}$ from their metabolism and calcium-rich diets to form calcium carbonate minerals in their cuticle (Norton and Behan-Pelletier 1991). A similar process has been described in the earthworm Lumbricus terrestris but here the formed calcium carbonate minerals are excreted as granules, presumably enhancing metabolic $\mathrm{CO}_{2}$ discharge (Canti 2009). If the carbonate is removed from the mites by addition of dilute $\mathrm{HCl}$ prior to stable isotope analysis, the ${ }^{13} \mathrm{C}$ signature decreases by about $4 \delta$ units (M.M. Pollierer, unpublished data; see signatures of Steganacarus magnus in Fig. 1). Interestingly, oribatid mite adults with atypical signatures are endophagous as juveniles, burrowing in decaying woody substrates or hard fungal sporophores as e.g., many Carabodes species (Norton and Behan-Pelletier 2009). In future studies using stable isotope signatures of animals that incorporate calcium carbonate in their cuticle those species should always be measured before and after the addition of diluted $\mathrm{HCl}$.

Stable isotope fractionation in below ground food webs from food resources (litter, roots, soil) to consumers (decomposer animals) differs greatly from that of above ground food webs. Usually, the $\delta^{15} \mathrm{~N}$ values of decomposers are only slightly higher than those of their resource, whereas the $\delta^{13} \mathrm{C}$ values are much higher (about 3-4 delta units). This enigma may at least in part be solved by the different stable isotope signatures of the respective food components that are included in litter, i.e. lignin, cellulose, starch, lipids, proteins and sugars (Bowling et al. 2008). The $\delta^{13} \mathrm{C}$ values of those components differ by about six delta units, and consumers only assimilate some components explaining their strong enrichment. In the future it is therefore highly recommended to measure not just the stable isotope signatures of potential food resources of decomposer animals but also those of the respective components (Pollierer et al. 2009).

The naturally high $\delta^{13} \mathrm{C}$ values of $\mathrm{C} 4$ plants, such as maize, sorghum and sugar cane, can be used for tracer experiments. These plants can be grown in the laboratory or in the field and their shoots and/or roots can be exposed in experimental plots of C3 plants; this allows following their characteristic ${ }^{13} \mathrm{C}$ signal in the soil microbial and animal food webs (Oelbermann et al. 2008, Schallhart et al. 2009). Establishing a litter-exchange experiment in the framework of the Swiss Canopy Crane Project (Körner et al. 2005) allowed separation of the role of leaf 
litter and root-derived resources for soil animal nutrition, showing that most of the carbon incorporated by soil animals originated from roots rather than leaf litter (Pollierer et al. 2007).

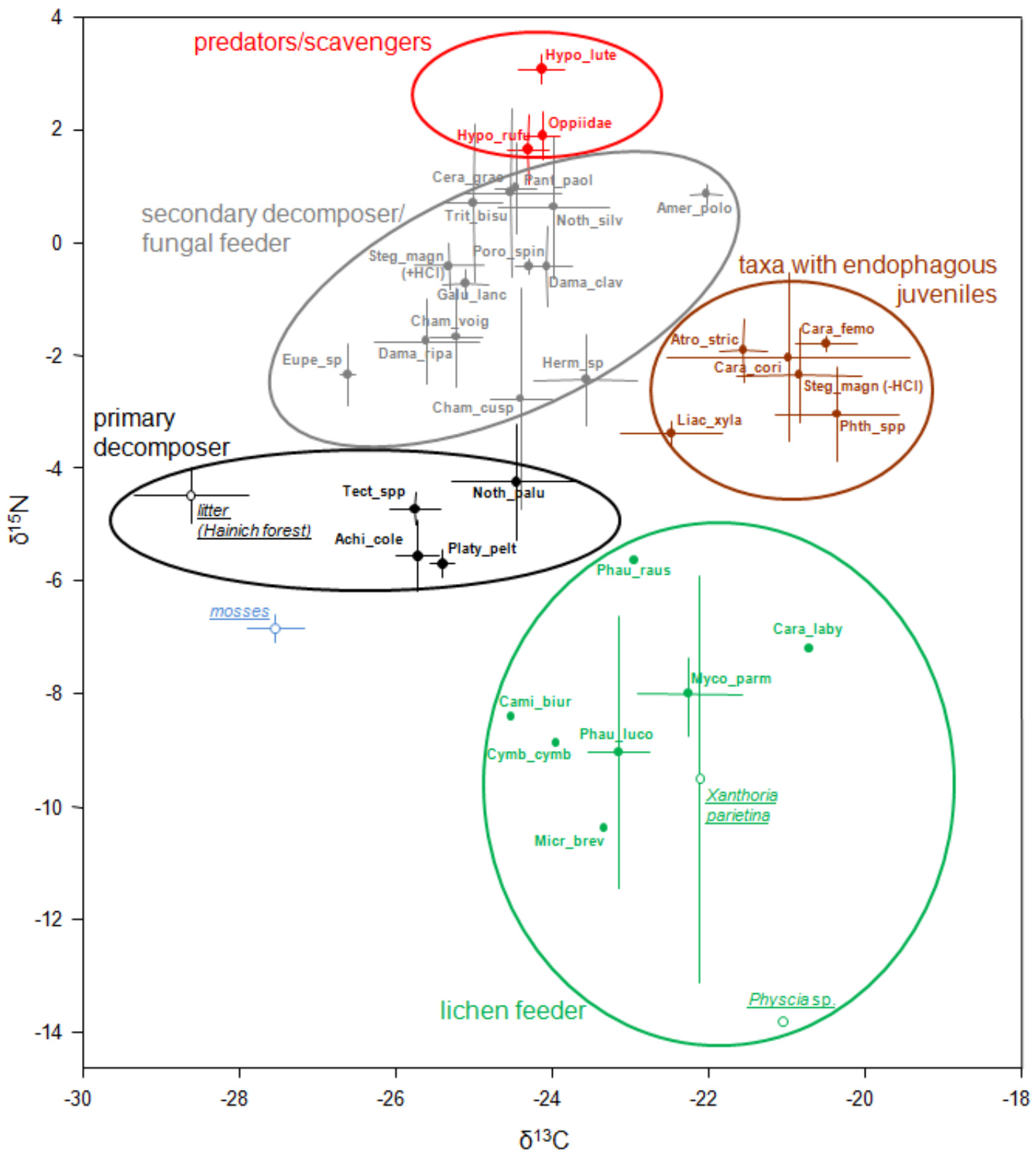

Fig. 1 Mean ( \pm standard deviation) of $13 \mathrm{C}$ and $15 \mathrm{~N}$ values of oribatid mite species and potential food resources (names underlined, in italics, symbols as open circles) in the Hainich forest in Germany and from a small forest stand in Fliess (Austria). Green circles group lichens and lichen feeders, mosses are marked in blue; decomposing material and primary decomposers are marked and circled in black; oribatid mite taxa that are endophagous as juveniles are marked and circled in brown; secondary decomposer/fungal feeding taxa are marked and circled in grey; and predatory/scavenging species are marked and circled in red; circles are drawn by eye. Using a calibration the stable isotope data of the soil living oribatid mite species remained unchanged, whereas the signatures of the bark living species were slightly changed (for details see text). See Table 1 for full names of oribatid mite species, potential food resources and number of replicates measured. Most data from mosses, lichens and lichen feeding oribatid mites (in green) are from Fischer et al. (2010); other data are from the Hainich, a beech forest in Germany (G. Erdmann, unpublished data). 
Tab. 1 Oribatid mite species names; their abbreviations used in fig. 1; their taxonomic affiliation; and their potential food resources

$\begin{array}{cc}\text { species names } & \text { abbrev. } \\ \text { groups* }\end{array}$

\section{oribatid mites}

Hypochthonius luteus Oudemans, 1917 Hypochthonius rufulus Koch, 1835

Steganacarus magnus (Nicolet, 1855)

Atropacarus striculus (Koch, 1835)

Phthiracaridae; undetermined

Nothrus silvestris Nicolet, 1855

Nothrus palustris Koch, 1839

Platynothrus peltifer (C.L. Koch, 1839)

Camisia biurus (Koch, 1839)

Hermannia sp; undetermined

Porobelba spinosa (Sellnick, 1920)

Damaeus clavipes (Hermann, 1804)

Damaeus riparius Nicolet, 1855

Tritegeus bisulcatus Grandjean, 1953

Amerus polonicus Kulczynski, 1902

Liacarus xylariae (Schrank, 1803)

Carabodes femoralis (Nicolet, 1855)

Carabodes coriaceus Koch, 1835

Carabodes labyrinthicus (Michael, 1879).

Pantelozetes paolii (Oudemans, 1913)

Tectocepheus spp.; undetermined

Cymbaeremaeus cymba (Nicolet, 1855)

Micreremus brevipes (Michael, 1888)

Eupelops sp.; undetermined

Achipteria coleoptrata (Linnaeus, 1758)

Phauloppia rauschenensis (Sellnick, 1908)

Phauloppia lucorum (Koch, 1841)

Ceratozetes gracilis (Michael, 1884)

Chamobates voigtsi (Oudemans, 1902)

Chamobates cuspidatus (Michael, 1884)

Mycobates parmeliae (Michael, 1884)

Galumna lanceata (Oudemans, 1900)

potential food resources

Xanthoria parietina (L.)

Physcia sp.

litter (Hanich forest)

mosses
Hypo_lute

Hypo_rufu

Steg_magn

Atro_stric

Phth_spp

Noth_silv

Noth_palu

Plat_pelt

Cami_biur

Herm_sp

Poro_spin

Dama_clav

Dama_ripa

Trit_bisu

Amer_polo

Liac_xyla

Cara_femo

Cara_cori

Cara_laby

Pant_paol

Tect_spp

Cymb_cymb

Micr_brev

Eupe_sp

Achi_cole

\section{Enarthronota}

Enarthronota

Mixonomata

Mixonomata

Mixonomata

Desmonomata

Desmonomata

Desmonomata

Desmonomata

Desmonomata

Damaeoidea

Damaeoidea

Damaeoidea

Cepheoidea

Ameroidea

Gustavoidea

Carabodoidea

Carabodoidea

Carabodoidea

Oppioidea

Tectocepheoidea

Cymbaeremaeoidea

Licneremaeoidea

Phenopelopoidea

Achipteroidea

Oripodoidea

Oripodoidea

Phau_luco

Cera_grac

Cham_voig

Cham_cusp

Myco_parm

Galu_lanc

Ceratozetoidea

Ceratozetoidea

Ceratozetoidea

Galumnoidea

lichen (Ascomycota)

lichen (Ascomycota)

beech leaf litter

undetermined mosses from

the bark of trees in Austria

* after Norton \& Behan-Pelletier (2009) 


\section{Challenges for the future}

When searching in literature databases for "oribatida" and "stable isotopes" six papers appear, of which five are from our group in Göttingen (formerly Darmstadt). This indicates that despite the high citation of the Schneider et al. (2004) paper few researchers have taken up our approach (Bokhorst et al. 2007). Perhaps this is because the measurements are expensive, or access to stable isotope facilities is not available, or soil ecologists believe there is little more to learn. We encourage scientists to use this methodology as it may help to answer some of the most persistent questions in soil animal ecology.

(1) The factors responsible for the high diversity of soil animal species on small spatial scales are still little understood. The contribution of generalist vs. specialist species to oribatid mite diversity needs considerable further attention (Maraun et al. 2003). Some oribatid mite species indeed appear to be trophic specialists, for example by predominantly feeding on lichens (e.g., Mycobates parmeliae; Fischer et al. 2010) or basidiomycete fungi (e.g., Haffenrefferia gilvipes, Caleremaeus monilipes and some species of Carabodes; D. Augustin and M. Maraun unpublished data, Matthewman and Pielou 1971, O'Connell and Bolger 1997). Additionally, the almost exclusive colonization of bark or the canopy region by some oribatid mite species (e.g., Carabodes labyrinthicus and Dometorina plantivaga, respectively; Wunderle 1992) may be due to trophic specialization. Further, the rather unique oribatid mite fauna in suspended soils on trees and rocks may reflect the presence of food resources that are only present in these microhabitats (Lindo and Winchester 2006, 2008). Some oribatid mite species, such as Trichoribates novus, Scheloribates laevigatus, Passalozetes africanus and Passalozetes intermedius, predominantly occur in arable systems and grassland, and this also may have a trophic basis (Fischer et al. 2010).

(2) There is very little overlap in the species composition of oribatid mites between temperate and tropical regions (Maraun et al. 2007), implying that despite their small size not every mite is everywhere (cf. Fenchel et al. 1997). One explanation for the lack of similarity may be trophic niche differentiation. Oribatid mites in tropical forests may feed on VAM fungi whereas oribatid mites of temperate regions may feed mainly on saprotrophic and ectomycorrhizal fungi. This hypothesis might be tested by using stable isotope signatures since saprotrophic and ectomycorrhizal fungi (and presumably also VAM fungi) have different stable isotope signatures (Hobbie et al. 2007). However, this approach is hampered by the difficulty in getting stable isotope data from hyphae of saprotrophic and mycorrhizal fungi (Tiunov 2007). 
(3) A particularly promising approach is combining stable isotope and fatty acid analysis using fatty acid stable isotope probing (Chamberlain et al. 2004, 2006; Haubert et al. 2009). Recent studies suggest that fatty acids can be traced over several trophic levels (Pollierer et al. 2010) and analyzing signatures of individual fatty acids in food chains may allow a much more detailed understanding of, e.g., the role of different basal resources, such as plant litter, bacteria and fungi, in soil animal food webs.

(4) In addition to using the natural variation of stable isotopes for the study of the trophic ecology of soil invertebrates, materials with exceptional stable isotope signatures and materials enriched with (or depleted in) stable isotopes can be used in laboratory and field experiments, e.g., beech litter can be labeled with $\delta^{15} \mathrm{~N}$ (Zeller et al. 2000) and this signature can be traced in the soil animal food web.

To follow the carbon signal through a food web, C4 plants (maize, sorghum, sugar cane) and their residues can be used. Furthermore, the plants themselves can be labeled using ${ }^{13} \mathrm{CO}_{2}$, which allows following the carbon signal from the plant into the rhizosphere as has been done for certain systems by Ruf et al. (2006) and Pollierer et al. (2007). The approach may help us understand under which conditions, and in which ecosystems, the soil animal food web predominantly relies on above- and belowground resources.

(5) Stable isotopes also may be used to investigate the transfer of carbon and nitrogen among different habitats and ecosystems. For example, a sugar cane field may be close to a forest and animals that are linked trophically to one (or both) systems can be distinguished. This may also work for transition zones between aquatic and terrestrial systems by tracing the signatures of allochthonous and autochthonous resources, e.g., in recently deglaciated regions (Kaufmann 2001), in glacial streams (Zah et al. 2001) and islands (Polis et al. 1997), and for separating aboveground from belowground systems (Bardgett et al. 2005). Furthermore, by labeling certain fungal or bacterial species it may be possible to distinguish bacterial and fungal food chains in soil.

(6) Finally, it is also important to find out factors that determine the isotopic compositions of whole animal bodies, e.g., dietary routing or food-tissue fractionation. Dietary routing implies that e.g., fatty acids are incorporated into consumer tissues without modification which has been shown for soil fungi and their grazers (Ruess et al. 2004). This in turn likely affects the fractionation of stable isotopes per trophic level. The stable isotope fractionation from the food resource to the consumer tissue may also differ greatly, e.g., the $\delta^{13} \mathrm{C}$ values of the fat body of Glomeris marginata (Diplopoda) are about three delta units $\left({ }^{13} \mathrm{C}\right.$ ) lower than those of the tergites indicating that the fractionation differs considerably between the 
different body tissues (M.M. Pollierer, unpublished data). Only some of that information can be obtained from descriptive studies; experimental approaches (i.e. laboratory feeding experiments) are needed to gain those data.

\section{Limitations and caveats}

The analysis of stable isotopes $\left({ }^{15} \mathrm{~N} /{ }^{14} \mathrm{~N}\right.$ and $\left.{ }^{13} \mathrm{C} /{ }^{12} \mathrm{C}\right)$ of oribatid mites is a success story that significantly contributed to our understanding of soil food webs, but it has limitations. While the method allows detection of trophic niches, it is of limited use for identifying precise food resources. This would be possible only if a resource had an unusual signature, e.g., bark living lichens, and if few other resources are available. Furthermore, the trophic levels are not distinct, e.g., some species in the middle of the trophic chain may be fungivorous but also may live as predators feeding on detritivores. Furthermore, since an individual's stable isotope signature integrates the assimilated food of weeks or months, important switches in food resources may be unnoticed. In addition, similar signatures can have different causes; e.g.,, an increase in $3.4 \delta$ units may result from feeding on a single resource one trophic level below the consumer, but also from a mixture of food resources with an average ${ }^{15} \mathrm{~N}$ signature $3.4 \delta$ units below that of the consumer. Therefore, the role of omnivory in soil animal food webs may be difficult to evaluate, but inspecting the standard deviation of stable isotope signatures may give hints on variations in the diet of consumers (Bearhop et al. 2004).

To conclude, the analysis of stable isotope ratios was and still is a very powerful method for understanding trophic niches of soil animal species and the trophic structure of soil invertebrate communities. Further, it allows us to evaluate basal resources of soil animal food webs and the role of trophic niches for animal diversity in ecosystems and microhabitats. We predict that the method will contribute significantly to illuminating these most pertinent issues in soil animal ecology in the near future. Their combination with other recently introduced methods, such as fatty acid and molecular gut content analyses, is about to revolutionize our understanding of the structure and functioning of the decomposer system. 


\section{Acknowledgements}

The work has been (partly) funded by the DFG Priority Program 1374 "InfrastructureBiodiversity-Exploratories". Field work permits were given by the responsible state environmental offices of Baden-Württemberg, Thüringen, and Brandenburg (according to $\S 72$ BbgNatSchG).

\section{References}

Altig, R., Whiles, M.R., Taylor, C.L. (2007) What do tadpoles really eat? Assessing the trophic status of an understudied and imperiled group of consumers in freshwater habitats. Freshwater Biology 52, 386-395.

Bardgett, R.D., Bowman, W.D., Kaufmann, R., Schmidt, S.K. (2005) A temporal approach to linking aboveground and belowground ecology. Trends in Ecology and Evolution 20, 634-641.

Bearhop, S., Adams, C.E., Waldron, S., Fuller, R.A., Macleod, H. (2004) Determining trophic niche width: a novel approach using stable isotope analysis. Journal of Animal Ecology 73, 1007-1012.

Blüthgen, N., Gebauer, G., Fiedler, K. (2003) Disentangling a rainforest food web using stable isotopes: dietary diversity in a species-rich ant community. Oecologia 137, 426-435.

Bokhorst, S., Ronfort, C., Huiskes, A., Convey, P., Aerts, R. (2007) Food choice of Antarctic soil arthropods clarified by stable isotope signatures, Polar Biology 30, 983-990.

Boutton, T.W., Arshad, M.A., Tieszen, L.L. (1983) Stable isotope analysis of termite food-habits in East-African grasslands. Oecologia 59, 1-6.

Bowling D.R., Pataki D.E., Randerson J.T. (2008) Carbon isotopes in terrestrial ecosystem pools and $\mathrm{CO}_{2}$ fluxes. New Phytologist 178, 24-40.

Canti, M.G. (2009) Experiments on the origin of ${ }^{13} \mathrm{C}$ in the calcium carbonate granules produced by the earthworm Lumbricus terrestris. Soil Biology \& Biochemistry 41, 2588-2592.

Chahartaghi, M., Langel, R., Scheu, S., Ruess, L. (2005) Feeding guilds in collembolan based on nitrogen stable isotope ratios. Soil Biology \& Biochemistry 37, 1718-1725.

Chamberlain, P.M., Bull, I.D., Black, H.I.J., Ineson, P., Evershed, R.P. (2004) Lipid content and carbon assimilation in Collembola: implications for the use of compound-specific carbon isotope analysis in animal dietary studies. Oecologia 139, 325-335.

Chamberlain, P.M., Bull, I.D., Black, H.I.J., Ineson, P., Evershed, R.P. (2006) The effect of diet on isotopic turnover in Collembola examined using the stable carbon isotopic compositions of lipids. Soil Biology \& Biochemistry 38, 1146-1157.

DeNiro, M.J., Epstein, S. (1981) Influence of diet on the distribution of nitrogen isotopes in animals. Geochimica et Cosmochimica Acta 45, 341-351.

Erdmann, G., Otte, V., Langel, R., Scheu, S., Maraun, M. (2007) The trophic structure of bark-living oribatid mite communities analysed with stable isotopes $\left({ }^{15} \mathrm{~N} ;{ }^{13} \mathrm{C}\right)$ indicates strong niche differentiation. Experimental and Applied Acarology 41, 1-10.

Fenchel, T., Esteban, G.F., Finlay, B.J. (1997) Local versus global diversity of microorganisms: cryptic diversity of ciliated protozoa. Oikos 80, 220-225. 
Fischer, B.M., Schatz, H., Maraun, M. (2010) Community structure, trophic position and reproductive mode of soil and bark-living oribatid mites in an alpine grassland ecosystem. Experimental and Applied Acarology 52, 221-237.

Gu, B.H., Schell, D.M., Alexander, V. (1994) Stable carbon and nitrogen isotopic analysis of the plankton food-web in a sub-arctic lake. Canadian Journal of Fisheries and Aquatic Sciences 51, 1338-1344.

Hall, R.O. (1995) Use of a stable carbon isotope addition to trace bacterial carbon through a stream food web. Journal of the North American Benthological Society 14, 269-277.

Haubert, D., Birkhofer, K., Fließbach, A., Gehre, M., Scheu, S., Ruess, L. (2009) Trophic structure and major trophic links in conventional vs. organic farming systems as indicated by carbon stable isotope ratios of fatty acids. Oikos 118, 1579-1589.

Hayes, A.J. (1979) The microbiology of plant litter decomposition. Science Progress 66, 25-42.

Heethoff, M., Norton, R.A., Scheu, S., Maraun, M. (2009) Parthenogenesis in oribatid mites (Acari, Oribatida). Evolution without sex. In: Schön, I., Martens, K., Van Dijk, P. (eds.), Lost sex: The evolutionary biology of parthenogenesis, pp. 241-257. Springer, Netherlands.

Hobbie, E.A., Rygiewicz, P.T., Johnson, M.G., Moldenke, A.R. (2007) ${ }^{13} \mathrm{C}$ and ${ }^{15} \mathrm{~N}$ in microarthropods reveal little response of Douglas-fir ecosystems to climate change. Global Change Biology 13, 1386-1397.

Hobbie, E.A. (2009) Linking ectomycorrhizal species composition to belowground function and exploration types. Journal of Nematology 41, 339-340.

Hobson, K.A., Piatt, J.F., Pitocchelli, J. (1994) Using stable isotopes to determine seabird trophic relationships. Journal of Animal Ecology 63, 786-798.

Hobson, K.A., Sease, J.L., Merrick, R.L., Piatt, J.F. (1997) Investigating trophic relationships of pinnipeds in Alaska and Washington using stable isotope ratios of nitrogen and carbon. Marine Mammal Science 13, 114-132.

Hudson, H.J. (1968) The ecology of fungi on plant remains above the soil. New Phytologist 67, 837874.

Kaufmann, R. (2001) Invertebrate succession on an alpine glacier foreland. Ecology 82, 2261-2278.

King, R.A., Read, D.S., Traugott, M., Symondson, W.O.C. (2008) Molecular analysis of predation: A review of best practice for DNA-based approaches. Molecular Ecology 17, 947-963.

Körner, C., Asshoff, R., Bignucolo, O., Hättenschwiler, S., Keel, S.G., Pelaez-Riedl, S., Pepin, S., Siegwolf, R.T.W., Zotz, G. (2005) Carbon flux and growth in mature deciduous forest trees exposed to elevated $\mathrm{CO}_{2}$. Science 309, 1360-1362.

Lindo, Z., Winchester, N.N. (2006) A comparison of microarthropod assemblages with emphasis on oribatid mites in canopy suspended soils and forest floors associated with ancient western redcedar trees. Pedobiologia 50, 31-41.

Lindo, Z., Winchester, N.N. (2008) Scale dependent diversity patterns in arboreal and terrestrial oribatid mite (Acari: Oribatida) communities. Ecography 31, 53-60.

Maraun, M., Migge, S., Schaefer, M., Scheu, S. (1998) Selection of microfungal food by six oribatid mite species (Oribatida, Acari) from two different beech forests. Pedobiologia 42, 232-240.

Maraun, M., Martens, H., Migge, M., Theenhaus, A., Scheu, S. (2003) Adding to the 'enigma of soil animal diversity': fungal feeders and saprophagous soil invertebrates prefer similar food substrates. European Journal of Soil Biology 39, 85-95.

Maraun, M., Schatz, H., Scheu, S. (2007) Awesome or ordinary? Global diversity patterns of oribatid mites. Ecography 30, 209-216. Martin A., Mariotti A., Balesdent J., Lavelle P. (1992) Soil organic 
matter assimilation by a geophagous tropical earthworm based on $\delta^{13} \mathrm{C}$ measurements. Ecology 73, 118-128.

Martinez del Rio, C., Wolf, N., Carleton, S.A., Gannes, L.Z. (2009) Isotopic ecology ten years after a call for more laboratory experiments. Biological Reviews 84, 91-111.

Matthewman, W.G., Pielou, D.P. (1971) Arthropods inhabiting the sporophores of Fomes fomentarius (Polyporacea) in Gatineau Park, Quebec. The Canadian Entomologist 103, 775-847.

Minagawa, M., Wada, E. (1984) Stepwise enrichment of N-15 along food-chains - further evidence and the relation between $\delta-\mathrm{N}-15$ and animal age. Geochimica et Cosmochimica Acta 48, 11351140.

Norton, R.A., Behan-Pelletier, V.M. (1991) Calcium carbonate and calcium oxalate as cuticular hardening agents in oribatid mites (Acari: Oribatida) Canadian Journal of Zoology 69, 1504-1511.

Norton, R.A., Behan-Pelletier, V.M. (2009) Suborder Oribatida. In: Krantz, G.W., Walter, D.E. (eds.), A manual of Acarology. 3rd edition, pp.430-564. Texas Tech University Press, Lubbock.

O'Connell, T., Bolger, T. (1997) Fungal fruiting bodies and the structure of fungus- micro-arthropod assemblages. Proceedings of the Royal Irish Academy 97B, 249-262.

Oelbermann, K., Langel, R., Scheu, S. (2008) Utilization of prey from the decomposer system by generalist predators of grassland. Oecologia 155, 605-617.

Osono, T. (2007) Ecology of ligninolytic fungi associated with leaf litter decomposition. Ecological Research 22, 955-974.

Polis, G.A., Anderson, W.B., Holt, R.D. (1997) Towards an integration of landscape and food web ecology: the dynamics of spatially subsidized food webs. Annual Review of Ecology and Systematics $28,289-316$.

Pollierer, M.M., Langel, R., Körner, C., Maraun, M., Scheu, S. (2007) The underestimated importance of belowground carbon input for forest soil food webs. Ecology Letters 10, 729-736.

Pollierer, M.M., Langel, R., Scheu, S., Maraun, M. (2009) Compartmentalization of the soil animal food web as indicated by dual analysis of stable isotopes $\left({ }^{15} \mathrm{~N} /{ }^{14} \mathrm{~N}\right.$ and $\left.{ }^{13} \mathrm{C} /{ }^{12} \mathrm{C}\right)$. Soil Biology \& Biochemistry 41, 1221-1226.

Pollierer, M.M., Scheu, S., Haubert, D. (2010) Taking it to the next level: Trophic transfer of marker fatty acids from basal resource to predators. Soil Biology \& Biochemistry 42, 919-925.

Ponsard, S., Arditi, R. (2000) What can stable isotopes $\left(\delta^{15} \mathrm{~N}\right.$ and $\left.\delta^{13} \mathrm{C}\right)$ tell us about the food web of soil macro-invertebrates? Ecology 81, 852-864.

Post, D.M. (2002) Using stable isotopes to estimate trophic position: models, methods, and assumptions. Ecology 83, 703-718.

Pringle, R.M., Fox-Dobbs, K. (2008) Coupling of canopy and understory food webs by grounddwelling predators. Ecology Letters 11, 1328-1337.

Riha, G. (1951) Zur Ökologie der Oribatiden in Kalksteinböden. Zoologische Jahrbücher Abteilung für Systematik Ökologie und Geographie der Tiere 80, 407-450.

Ruess, L., Häggblom, M.M., Langel, R., Scheu, S. (2004) Nitrogen isotope ratios and fatty acid composition as indicators of animal diets in belowground systems. Oecologia 139, 336-346.

Ruess, L., Schütz, K., Haubert, D., Häggblom, M.M., Kandeler, E., Scheu, S. (2005a) Application of lipid analysis to understand trophic interactions in soil. Ecology 86, 2075-2082.

Ruf, A., Kuzyakov, Y., Lopatovskaya, O. (2006) Carbon fluxes in soil food webs of increasing complexity revealed by ${ }^{14} \mathrm{C}$ labelling and ${ }^{13} \mathrm{C}$ natural abundance. Soil Biology \& Biochemistry 38 , 2390-2400. 
Schallhart, N., Wallinger, C., Juen, A., Traugott, M. (2009) Dispersal abilities of adult click beetles in arable land revealed by analysis of carbon stable isotopes. Agricultural and Forest Entomology 11, 333-339.

Scheu, S., Falca, M. (2000) The soil food web of two beech forests (Fagus sylvatica) of contrasting humus type: stable isotope analysis of a macro- and a mesofauna-dominated community. Oecologia 123, 285-296.

Schmidt, O., Ostle, N.J. (1999) Tracing nitrogen derived from slurry in earthworms using N-15/N-14 stable isotope ratios at natural abundances. Applied Soil Ecology 12, 7-13.

Schmidt, O., Curry, J.P., Dyckmans, J., Rota, E., Scrimgeour, C.M. (2004) Dual stable isotope analysis $\left(\delta^{13} \mathrm{C}\right.$ and $\left.\delta^{15} \mathrm{~N}\right)$ of soil invertebrates and their food sources. Pedobiologia $48,171-180$.

Schneider, K., Migge, S., Norton, R.A., Scheu, S., Langel, R., Reineking, A., Maraun, M. (2004) Trophic niche differentiation in soil microarthropods (Oribatida, Acari): evidence from stable isotope ratios $\left({ }^{15} \mathrm{~N} /{ }^{14} \mathrm{~N}\right)$. Soil Biology \& Biochemistry 36, 1769-1774.

Sholto-Douglas, A.D., Field, J.G., James, A.G., van der Merve, N.J. $(1991){ }^{13} \mathrm{C} /{ }^{12} \mathrm{C}$ and ${ }^{15} \mathrm{~N} /{ }^{14} \mathrm{~N}$ isotope ratios in the Southern Benguela Ecosystem: indicators of food web relationships among different size-classes of plankton and pelagic fish; differences between fish muscle and bone collagen tissues. Marine Ecology Progress Series 78, 23-31.

Struck, U., Altenbach, A.V., Gaulke, M., Glaw, F. (2002) Tracing the diet of the monitor lizard Varanus mabitang by stable isotope analyses $\left(\delta^{15} \mathrm{~N}, \delta^{13} \mathrm{C}\right)$. Naturwissenschaften $89,470-473$.

Tayasu, I. (1998) Use of carbon and nitrogen isotope ratios in termite research. Ecological Research 13, 377-387.

Tiunov, A.V. (2007) Stable isotopes of carbon and nitrogen in soil ecological studies. Biology Bulletin 34, 395-407.

Wada, E., Mizutani, H., Minagawa, M. (1991) The use of stable isotopes for food web analyses. Critical Reviews in Food Science and Nutrition 30, 361-371.

Walter, D.E. (1987) Trophic behaviour of mycophagous microarthropods. Ecology 68, 226-229.

Wunderle, I. (1992) Die Oribatiden-Gemeinschaft (Acari) der verschiedenen Habitate eines Buchenwaldes. Carolinea 50, 79-144.

Zah, R., Burgherr, P., Bernasconi, S.M., Uehlinger, U. (2001) Stable isotope analysis of macroinvertebrates and their food sources in a glacier stream. Freshwater Ecology 46, 871-882.

Zeller, B., Colin-Belgrand, M., Dambrine, E., Martin, F., Bottner, P. (2000) Decomposition of N-15labelled beech litter and fate of nitrogen derived from litter in a beech forest. Oecologia 123, 550-559 


\section{Appendix}

Appendix 1 Species, no. of replicates of stable isotope measurement for each species, mean number of measured individuals per replicate and mean dry weight $(\mathrm{mg})$ per individual of the stable isotope data of the species from forest soil in Hainich (Germany)

\begin{tabular}{|c|c|c|c|c|}
\hline & Species & $\begin{array}{l}\text { No. of } \\
\text { replicates }\end{array}$ & $\begin{array}{l}\text { Mean no. of } \\
\text { individuals } \\
\text { per replicate }\end{array}$ & $\begin{array}{l}\text { Dry weight } \\
\text { per individual } \\
(\mathrm{mg})\end{array}$ \\
\hline \multicolumn{5}{|l|}{ Enarthronota } \\
\hline \multirow[t]{2}{*}{ Hypochthonioidea } & Hypochthonius luteus Oudemans, 1917 & 7 & 23,7 & 0,00509 \\
\hline & Hypochthonius rufulus C.L. Koch 1835 & 9 & 9,8 & 0,01798 \\
\hline \multicolumn{5}{|l|}{ Mixonomata } \\
\hline \multirow[t]{3}{*}{ Phthiracaroidea } & Atropacarus striculus (C.L. Koch, 1835) & 12 & 43,3 & 0,00785 \\
\hline & Phthiracarus spp. & 6 & 6,4 & 0,06564 \\
\hline & Steganacarus magnus (Nicolet, 1855) & 14 & 2,4 & 0,13856 \\
\hline \multicolumn{5}{|l|}{ Desmonomata } \\
\hline \multirow[t]{3}{*}{ Crotonioidea } & Nothrus palustris C.L. Koch, 1839 & 3 & 2,3 & 0,05557 \\
\hline & Nothrus silvestris Nicolet, 1855 & 3 & 4,3 & 0,02162 \\
\hline & Platynothrus peltifer (C.L. Koch, 1839) & 4 & 4,3 & 0,03359 \\
\hline Hermannielloidea & Hermaniella sp. & 5 & 5,2 & 0,02031 \\
\hline \multicolumn{5}{|l|}{ Brachypylina } \\
\hline \multirow[t]{2}{*}{ Damaeoidea } & Damaeus clavipes (Hermann, 1804) & 2 & 2,0 & 0,30600 \\
\hline & Damaeus riparius Nicolet, 1855 & 12 & 2,8 & 0,10142 \\
\hline Cepheoidea & Tritegeus bisulactus Grandjean, 1953 & 2 & 1,5 & 0,33833 \\
\hline Gustavioidea & Liacarus xylariae (Schrank, 1803) & 6 & 3,7 & 0,02959 \\
\hline \multirow[t]{2}{*}{ Carabodoidea } & Carabodes coriaceus C.L. Koch, 1835 & 2 & 3,0 & 0,05000 \\
\hline & Carabodes femoralis (Nicolet, 1855) & 3 & 7,7 & 0,02370 \\
\hline Tectocepheoidea & Tectocepheus spp. & 1 & 80,0 & 0,00150 \\
\hline \multirow[t]{2}{*}{ Oppioidea } & Oppiella spp. & 9 & 167,8 & 0,00122 \\
\hline & Pantelozetes paolii (Oudemans, 1913) & 5 & 12,4 & 0,00348 \\
\hline \multirow[t]{2}{*}{ Phenopelopoidea } & Eupelops hirtus (Berlese, 1916) & 4 & 3,8 & 0,07240 \\
\hline & Eupelops plicatus (C.L. Koch, 1836) & 8 & 3,0 & 0,03946 \\
\hline Achipterioidea & Achipteria coleoptrata (Linnè, 1758) & 14 & 7,4 & 0,02271 \\
\hline Galumnoidea & Galumna lanceata Oudemans, 1900 & 3 & 2,7 & 0,06363 \\
\hline \multirow[t]{3}{*}{ Ceratozetoidea } & Ceratozetes gracilis (Michael, 1884) & 11 & 7,0 & 0,01144 \\
\hline & Chamobates cuspidatus (Michael, 1884) & 4 & 12,5 & 0,00436 \\
\hline & Chamobates voigtsi (Oudemans, 1902) & 8 & 35,5 & 0,00379 \\
\hline
\end{tabular}




\title{
Chapter 3
}

\section{Regional factors rather than forest type drive the community structure of soil living oribatid mites (Acari, Oribatida)}

\author{
Erdmann, G., Scheu, S., Maraun M.
}

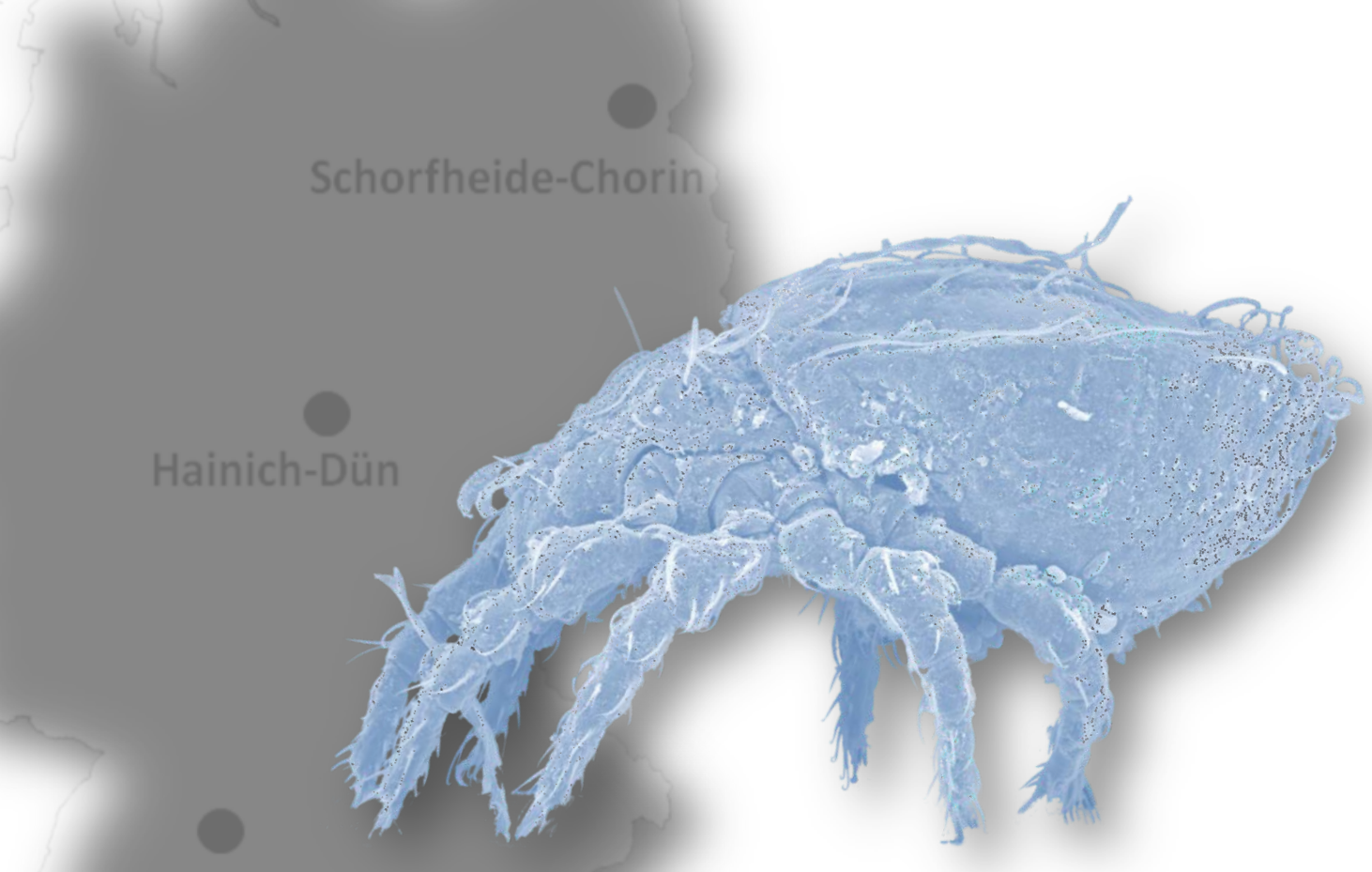

Schwäbische Alb

published in:

Erdmann, G., Scheu, S., Maraun, M. (2012) Regional factors rather than forest type drive the community structure of soil living oribatid mites (Acari, Oribatida).

Experimental and Applied Acarology, 57, 157-169. 


\section{Abstract}

Most European forests are managed by humans. However, the manner and intensity of management vary. While the effect of forest management on above-ground communities has been investigated in detail, effects on the belowground fauna remain poorly understood. Oribatid mites are abundant microarthropods in forest soil and important decomposers in terrestrial ecosystems. Here, we investigated the effect of four different forest types (managed coniferous forests; 30 y, 70 y old managed age class beech forests; natural beech forests) on the density, diversity and community structure of oribatid mites (Acari). The study was replicated at three regions in Germany: the Swabian Alb, the Hainich and the Schorfheide. For relating changes in oribatid mite community structure to environmental factors litter mass, $\mathrm{pH}$, $\mathrm{C}$ and $\mathrm{N}$ content of litter, fine roots and C content of soil were measured. Density of oribatid mites was highest in the coniferous forests and decreased in the order $30 \mathrm{y}$ and $70 \mathrm{y}$ old, and natural beech forests. Mass of the litter layer and density of oribatid mites were strongly correlated indicating that the litter layer is the most important factor regulating oribatid mite densities. Diversity of oribatid mites was little affected by forest type indicating that they harbor similar numbers of niches. Species composition differed between the forest types, suggesting different types of niches. The community structure of oribatid mites differed more strongly between the three regions than between the forest types indicating that regional factors are more important than effects associated with forest type.

\section{Introduction}

Central Europe comprises old cultivated land, modified by humans since thousands of years. Different management regimes influenced today's fauna and flora. Today about $30 \%$ of Central Europe is covered by forests (European Environment Agency 2005). The overwhelming part of forest areas in Europe is subject to silviculture. The major form of forest management type is age-class forest (Fischer et al. 2010). These forests lack variability in age structure and stand composition. For economic reasons managed forests are dominated by beech, oak, pine and spruce (Ellenberg 1996). Beech is the natural occurring and most common tree species in central Europe, in contrast to spruce which was introduced into lowland ecosystems. In dry lowland regions pine was planted instead of spruce (Ellenberg 1996). 
Silvicultural practices alter natural succession processes and decrease spatial heterogeneity of resources and environmental conditions (Halpern and Spies 1995). Thinning, harvesting and hauling of mature trees take place in managed forests causing drastic disturbances. The type of forest management affects plant diversity (Halpern and Spiess 1995) and community structure of aboveground animals, such as carabid beetles (Werner and Raffa 2000; Niemelä et al. 2007) and spiders (Brennan et al. 2006). Furthermore, ant, carabid beetle and spider diversity increase with increasing forest age (Niemelä et al. 1996). Paillet et al. (2010) found an overall increase in species richness in natural temperate and boreal forests in Europe in comparison to managed forests with bryophytes, lichens, fungi, saproxylic beetles and carabids being most affected. However, the effect of different forest management types on belowground organisms has been little studied (but see e.g. Lindo and Visser 2004; Cassagne et al. 2006). Forest management may reduce soil organic matter, increase soil compaction, change plant cover and modify microclimate. All of these effects affect the distribution, composition and activity of soil animal communities (Marshall 2000).

Despite the seemingly homogeneous habitat soil organisms live in (Giller 1996), the diversity of soil animals is very high. This phenomenon has been termed the "enigma of soil animal diversity" (Anderson 1975). Especially the microarthropod taxa, such as Collembola and oribatid mites (Acari), have a high diversity with about 100 species in European forests (Norton and Behan-Pelletier 2009). Moreover, oribatid mites are abundant in virtually any forest reaching densities between 20,000 ind. $/ \mathrm{m}^{2}$ in base rich forests and 200,000 ind./ $\mathrm{m}^{2}$ in acidic forests (Maraun and Scheu 2000). Oribatid mites are mainly decomposers feeding on dead organic material and fungi; however, recently is has been postulated that they also live directly or indirectly from rhizosphere carbon (Pollierer et al. 2007), feed on lichens (Erdmann et al. 2007), as well as on dead or living animals (Maraun et al. 2011; Heidemann et al. 2011). Stable isotope signatures indicate that they span about three to four trophic levels including decomposers, fungal feeders, scavengers and predators (Schneider et al. 2004).

The aim of this study was to identify general patterns of the effect of forest management and forest type on density, diversity and community structure of soil living oribatid mites in four different forest types: 30 y and 70 y old beech forests (Fagus sylvatica), natural beech forests (mature trees being approx. 120 y old) and $70 \mathrm{y}$ old coniferous forests at large geographic ranges in Central Europe. The study was replicated at three regions in Germany; the Swabian Alb (Baden-Wuerttemberg), the Hainich (Thuringia) and the Schorfheide (Brandenburg) spanning a latitudinal gradient of more than $500 \mathrm{~km}$. Due to soil and climate 
conditions coniferous forests in the Hainich and Alb consist of spruce (Picea abies) and in Schorfheide of pine (Pinus sylvestris).

We hypothesized that (1) oribatid mite density is highest in forests with thick organic layers (i.e., in acidic coniferous forests) providing habitat and food; (2) the diversity of oribatid mites is highest in unmanaged (natural) forests due to low disturbance and high microhabitat diversity and heterogeneity; and (3) the community structure of oribatid mites differs between forest types providing different types of niches.

\section{Materials and Methods}

\subsection{Study sites}

We used experimental forest sites at three regions in Germany selected for long-term monitoring in the framework of the Biodiversity Exploratories, an integrative ecosystem research project (www.biodiversity-exploraties.de). The regions are located in the Swabian Alb, a low-mountain range in South-Western Germany (460-860 m a.s.l.), the Hainich, a hilly region in central Germany (285-550 m a.s.l.), and the Schorfheide, a glacial formed landscape in North-Eastern Germany (3-140 m a.s.l.). Parent rock is Jurassic shell limestone in the Swabian Alb, Triassic limestone in the Hainich and glacial till in the Schorfheide. Soil types at the study sites in the Swabian Alb are mainly Cambisols and partially Leptosols. In the Hainich Luvisol represent the main soil type and to a lesser extent Cambisol and Stagnosol. The Schorfheide is dominated by Cambisols interspersed with Luvisols (Fischer et al. 2010). Acidity of the soil ranged from pH $3.3 \pm 0.19$ in the Schorfheide to $4.51 \pm 0.72$ in the Swabian Alb to $4.59 \pm 0.67$ in the Hainich. The mean annual precipitation in the Swabian Alb is 700-1000 mm with a mean annual temperature of $6-7^{\circ} \mathrm{C}$; respective values at the Hainich and the Schorfheide are $500-800 \mathrm{~mm}$ and $6.5-8^{\circ} \mathrm{C}$, and $500-600 \mathrm{~mm}$ and $8-8.5^{\circ} \mathrm{C}$. More details on the Biodiversity Exploratories are given in Fischer et al. (2010).

\subsection{Sampling design}

Four forest types were investigated in each of the three regions, including approximately $70 \mathrm{y}$ old coniferous forests (Picea abies in the Swabian Alb and Hainich; Pinus sylvestris in the Schorfheide), 30 and 70 y old beech forests (Fagus sylvatica) and natural beech forests with mature trees being 120 to 150 y old. The coniferous forests as well as the 30 and 70 year old 
beech forests were planted forests (=age class forests); the natural forests were taken out of management at different dates (for details see Fischer et al. 2010).

Soil samples were taken in April and May 2008. The four forest types were replicated four times in each of the three regions resulting in 48 sampled forests. The forests were at least 1 $\mathrm{km}$ aside from each other. In each forest two soil cores were taken from a $5 \times 5 \mathrm{~m}$ square and pooled for statistical analysis. Soil cores were taken with a soil corer $(5 \mathrm{~cm} \varnothing)$ and separated into organic and soil layer ( $4 \mathrm{~cm}$ thickness). Soil animals were extracted by heat (Macfadyen 1961) from both layers separately but data were pooled for the statistical analyses. Until determination animals were stored in $70 \%$ ethanol. Adult oribatid mites were determined using Weigmann (2006). Suctobelbidae and Brachychthoniidae were determined to familylevel; juvenile oribatid mites were counted.

\subsection{Environmental factors}

The litter layer of the soil cores used for arthropod extraction was weighed after drying during heat extraction. Soil pH of the soil cores was measured in $0.01 \mathrm{M} \mathrm{CaCl}_{2}$ solution. Carbon and nitrogen content of the litter and of fine roots, taken out of the soil cores after heat extraction, as well as carbon content of the soil were measured with an elemental analyzer (NA 1500, Carlo Erba, Milan).

\subsection{Statistical analysis}

Data of oribatid mite density and diversity were log transformed (counted data) or arc-sine transformed (proportional data) to improve homogeneity of variances and normal distribution; and analyzed using two-factorial ANOVA with the factors region (Swabian Alb, Hainich, Schorfheide) and forest type (coniferous forest, beech $30 \mathrm{y}$ old, beech $70 \mathrm{y}$ old, natural beech forest). In case of significance post-hoc tests (Tukey's HSD) were performed to inspect differences between means. Means and standard deviations given in text and figures are based on untransformed data. Correlations of oribatid mite density with environmental factors were tested using Pearson Correlation. ANOVA and correlations were calculated with STATISTICA 9.1 software package (Statsoft, Tulsa, USA).

The impacts of different levels of the treatments forest type and region on oribatid mite community composition were analyzed separately conducting two Discriminant Functional Analyses (DFA) following the procedure given in Tiunov and Scheu (2000). Species which occurred in less than four plots were excluded from the analysis. The DFA was performed using STATISTICA 9.1 software package (Statsoft Tulsa, USA). Multidimensional scaling (MDS) was 
carried out prior to DFA to reduce the number of dimensions. Reduction to six dimensions was the best solution to minimize dimensions. Forest type or region were used as grouping variables in DFA and Squared Mahalanobis Distances between group centroids and the reliability of the sample classifications were determined. The extracted significant roots were correlated (Pearson) with environmental data to identify factors which are responsible for differences between forest types and regions.

Ordination techniques were applied to correlate species and environmental factors structuring the communities in the regions and forest types. For Canonical Correspondence Analysis (CCA) species (present in at least 4 independent samples) and environmental data were log-transformed; forest types were coded as supplementary variables. CCA was performed using CANOCO 4.5 (Jongman et al. 1995; Braak and Smilauer 2002).

\section{Results}

\subsection{Oribatid mite density}

Oribatid mite density (adults and juveniles together) differed significantly between the four forest types $\left(F_{3,36}=7.36 ; p<0.001\right.$; Fig. 1$)$, it decreased from coniferous forests $(117.352 \pm$ 74.266 ind. $\left./ \mathrm{m}^{2}\right)$ over $30 \mathrm{y}$ old beech forests $\left(59.920 \pm 38.721 \mathrm{ind} . / \mathrm{m}^{2}\right)$ and $70 \mathrm{y}$ old beech forests $\left(53.683 \pm 53.953\right.$ ind. $\left./ \mathrm{m}^{2}\right)$ to natural beech forests $\left(32.985 \pm 17.134 \mathrm{ind} . / \mathrm{m}^{2}\right)$. Oribatid mite densities did not differ significantly between the three regions $\left(F_{2,36}=2.61 ; p=0.09\right.$; $59.814 \pm 45.126,53.451 \pm 61.725$ and $84.690 \pm 64.799$ ind. $/ \mathrm{m}^{2}$ for the Swabian Alb, Hainich and Schorfheide, respectively).

The proportion of juveniles (approx. $25 \%$ of all individuals) did not differ significantly between forest types $\left(F_{3,36}=1.08 ; p=0.37\right)$ but between the regions $\left(F_{2,36}=6.49 ; p=0.004\right)$. The proportion of juveniles was at a maximum in the Schorfheide with $32.5 \% \pm 13.0$ and significantly lower in the Swabian Alb with $19.3 \% \pm 10.4$, with the proportion in the Hainich being intermediate $23.1 \% \pm 9.4$ (and not significantly different from the two other regions).

Oribatid mite density was positively correlated with the mass of litter layer $\left(r^{2}=0.18, p=\right.$ $0.003)$, the concentration of carbon in litter $\left(r^{2}=0.12, p=0.015\right)$ and the concentration of carbon in soil $\left(r^{2}=0.10, p=0.026\right)$, and negatively correlated with $\mathrm{pH}\left(r^{2}=0.23, p=0.001\right)$, concentration of nitrogen in fine roots $\left(r^{2}=0.14, p=0.01\right)$ and concentration of nitrogen in litter $\left(r^{2}=0.11, p=0.03\right)$. 


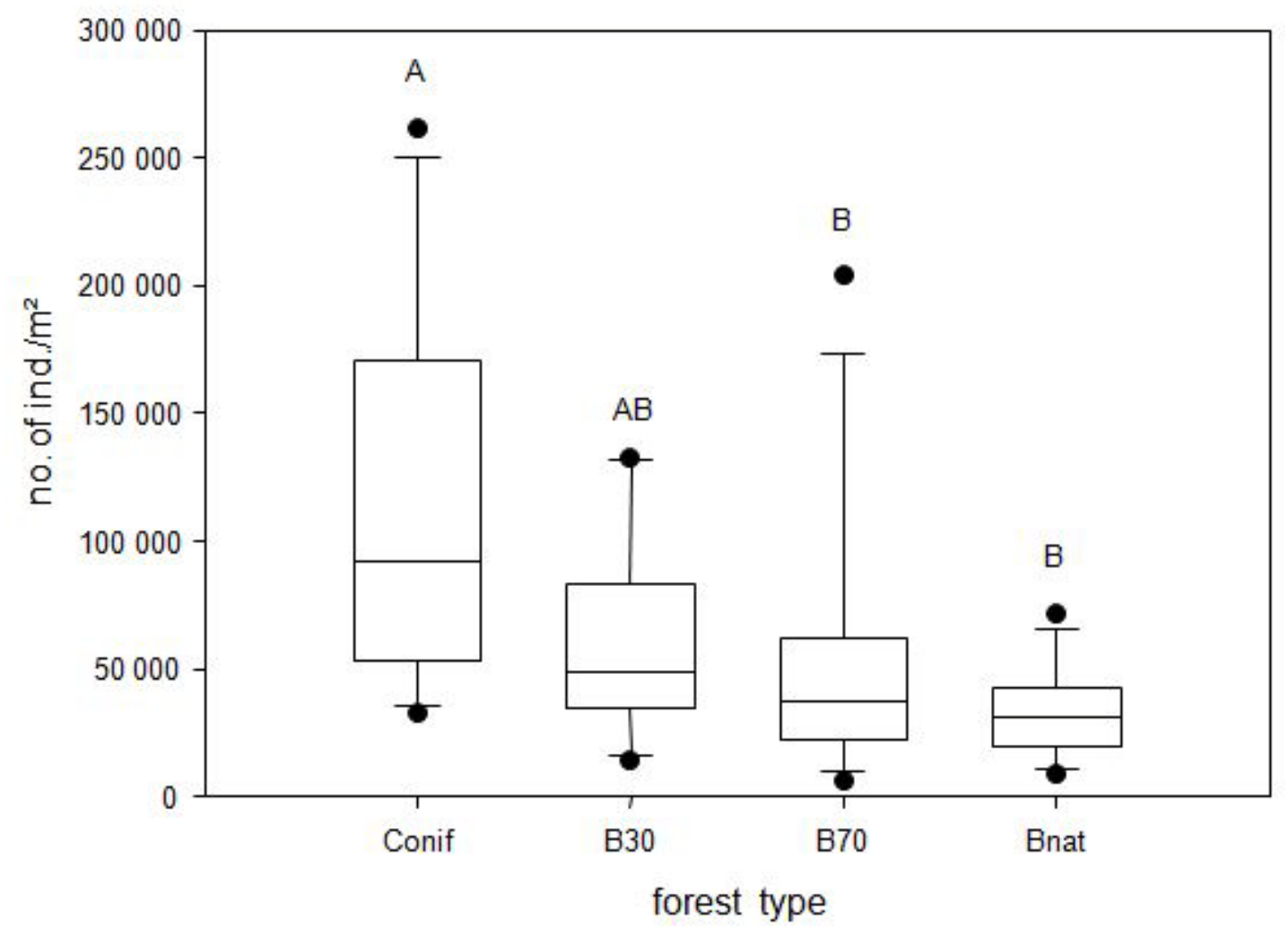

Fig. 1 Oribatid mite density in different forest types (Conif = coniferous forest; $B 30=30$ y old beech forest; $B 70=70$ y old beech forest; Bnat = natural beech forest). Boxes indicate the 25th and 75th percentile, the line in the box marks the median, whiskers map the 90th and 10th percentile; dots display outliers; different letters indicate significant differences between means (Tukey's Honestly Significant Difference test, $p<0.05$ ).

\subsection{Species numbers of oribatid mites}

Overall, 114 species of oribatid mites were found. The total number of species was highest in the Swabian Alb (78), lower in the Schorfheide (65), and lowest in the Hainich (57), with on average 79 and 78 species in coniferous and $30 \mathrm{y}$ old beech forests, respectively, and 64 species in both the $70 \mathrm{y}$ old and natural beech forests. The average number of species per soil sample differed significantly between forest types $\left(F_{3,36}=3.02, p=0.04\right)$. Although the total number of oribatid mites was highest in the Swabian Alb, lower in the Schorfheide and lowest in the Hainich, the average number of oribatid mite species per sample did not differ between regions $\left(F_{2,36}=0.08, p=0.92\right)$, but variations with forest type differed between regions (significant region $\times$ forest type interaction; $F_{6,36}=3.77, p=0.005$ ), with the number of oribatid mite species per sample being highest in the coniferous forests of the Swabian Alb and lowest in the $70 \mathrm{y}$ old and natural beech forests of the Schorfheide (Fig. 2). 


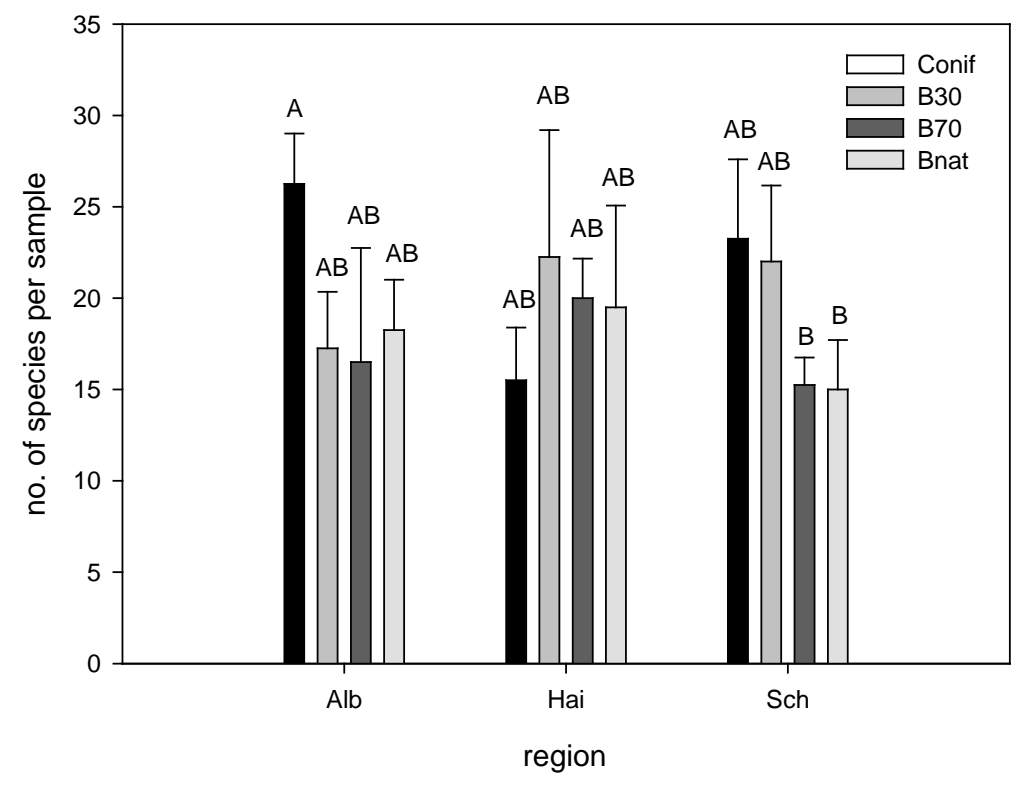

Fig. 2 Number of oribatid mite species per sample in the three regions of the Biodiversity Exploratories (Alb = Swabian Alb; Hai = Hainich; Sch = Schorfheide) and the forest types (Conif = coniferous forest; $\mathrm{B} 30=30 \mathrm{y}$ old beech forest; $\mathrm{B} 70=70 \mathrm{y}$ old beech forest; $\mathrm{Bnat}=$ natural beech forest; different letters indicate significant differences between means (Tukey's Honestly Significant Difference test, $p<0.05)$ ).

\subsection{Community structure of oribatid mites}

Oribatid mite communities differed significantly between the four forest types (DFA: Wilk's Lambda $\left.=0.21, \mathrm{~F}_{18,110}=4.57, \mathrm{p}<0.0001\right)$. The first of three extracted roots was significant and the oribatid mite communities of the forest types were separated along this axis. Oribatid mite communities of coniferous forests differed significantly from beech forests; but also among beech forests they differed significantly between $30 \mathrm{y}$ old forests and natural forests. Generally, oribatid mite communities changed gradually from coniferous forests over 30 y old beech forests and $70 \mathrm{y}$ old beech forests to natural beech forests. The mass of litter layer correlated positively $\left(r^{2}=0.21, p=0.001\right)$ and nitrogen concentrations in fine roots correlated negatively $\left(r^{2}=0.118, p=0.017\right)$ with the first DFA root.

Oribatid mite species compositions also significantly differed between the three regions (DFA: Wilk's Lambda $=0.02, F_{12,80}=32.63, p<0.0001$ ). The oribatid mite community of the Schorfheide was separated along the first root from the other regions (Mahalanobis Distance (MD) between Schorfheide and Swabian Alb 41.37, $F_{6,40}=49.03, p<0.0001$, and between 
Schorfheide and Hainich 32.97, $\left.F_{6,40}=39.08, p<0.0001\right)$. The second root separated Hainich and Swabian Alb (MD $=17.06, F_{6,40}=20.22, p<0.0001$ ). Soil pH correlated negatively with the first root $\left(r^{2}=0.524, p<0.001\right)$ and positively with carbon concentrations in fine roots $\left(r^{2}=0.205\right.$, $p=0.001)$. The second root correlated negatively with mass of litter layer $\left(r^{2}=0.184, p=0.002\right)$ and positively with nitrogen concentrations in fine roots $\left(r^{2}=0.106, p=0.024\right)$.

Oribatid mite community varied most between the three regions but not between forest types (Canonical Correspondence Analysis, CCA; Fig. 3). Along the first CCA axis Schorfheide was separated from Swabian Alb and Hainich. Among environmental factors soil pH correlated closest with the first axis with higher acidity in the Schorfheide and more alkaline conditions in the Swabian Alb and Hainich. Oribatid mite communities of the Swabian Alb and Hainich also differed and were separated along the second axis. The second axis correlated closely with mass of litter layer with higher values in the Swabian Alb than the Hainich than in the Schorfheide, and with concentrations of carbon and nitrogen in fine roots with higher values in the Hainich than in the Swabian Alb. Some oribatid mite species analyzed in the CCA exclusively occurred in one of the three Biodiversity Exploratories: Chamobates subglobulus, Microtritia minima and Oppiella propinqua only occurred in the Schorfheide, Oppiella obsoleta and Tectocepheus minor only in the Hainich, and Quadroppia hammerae and Tectocepheus velatus velatus only in the Swabian Alb.

In each of the three regions oribatid mite community composition in coniferous forests differed from that in beech forests. CCA indicated that this is due to lower $\mathrm{pH}$ in soil and higher mass of litter layer in coniferous forests. Coniferous forests were characterized by the oribatid mite species Chamobates borealis, Phthiracarus Iongulus, Platynothrus peltifer, Tectocepheus velatus alatus (except in the Swabian Alb) and high densities of Brachychthoniidae and Suctobelbidae. Oribatid mite species typical for 70 y old and natural beech forests were Atropacarus striculus, Ceratozetes gracilis (except in the Schorfheide), Chamobates cuspidatus, Damaeus riparius and Steganacarus magnus. The oribatid mite community in coniferous forests in Schorfheide (pine) differed from each of the other sites with high abundances of Adoristes ovatus, Carabodes labyrinthicus, Carabodes ornatus, Oppiella propinqua and Tectocepheus velatus sarekensis. Coniferous forests in Schorfheide were characterized by low soil pH, high mass of litter layer and low concentrations of nitrogen and carbon in fine roots. 


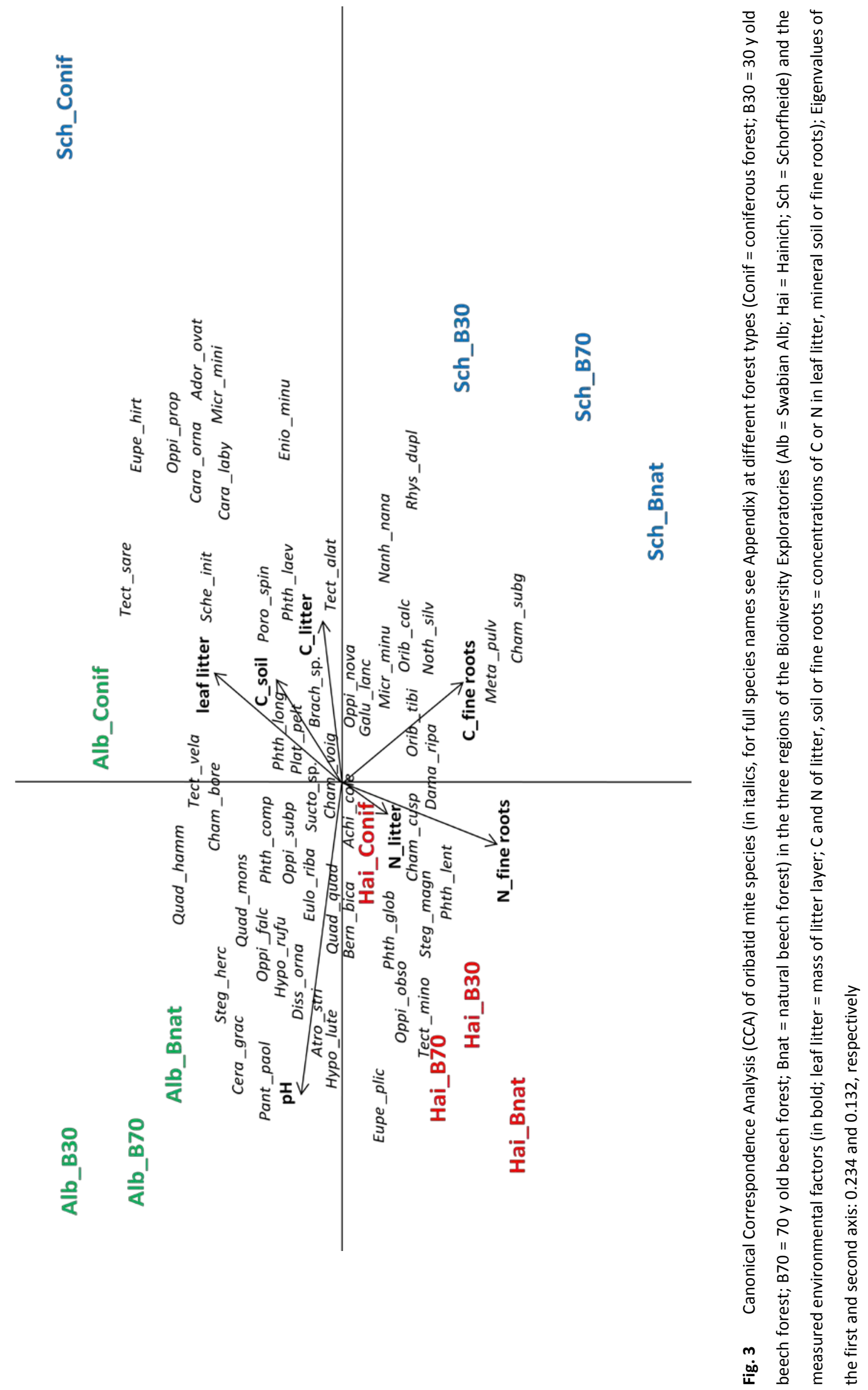




\section{Discussion}

\subsection{Oribatid mite density}

Oribatid mite densities in the four forest types were highest in the coniferous forests $\left(\sim 120.000 \mathrm{ind} / \mathrm{m}^{2}\right)$, lower in the $30 \mathrm{y}$ old $\left(\sim 60.000 \mathrm{ind} / \mathrm{m}^{2}\right)$ and the $70 \mathrm{y}$ old $\left(\sim 50.000 \mathrm{ind} / \mathrm{m}^{2}\right)$ beech forests and lowest in the natural beech forests $\left(\sim 30.000 \mathrm{ind} / \mathrm{m}^{2}\right)$. High density of oribatid mites in coniferous compared to deciduous forests of the temperate zone have been reported before. Maraun and Scheu (2000) concluded that it is the humus form that affects oribatid mite densities with high densities in acidic mor and moder systems and low densities in base rich mull soils. A large number of biotic and abiotic factors correlate with the humus form including $\mathrm{pH}$ and presence of macroarthropods (Schaefer and Schauermann 1990), complicating disentangling causal mechanisms responsible for the differential density of oribatid mites. In our study oribatid, mite density correlated closely with the mass of litter layer suggesting that the thickness of the litter layer rather than the humus form determines oribatid mite densities (Migge et al. 1998; Osler et al. 2006). Forest type and tree species affect litter thickness thereby also affecting oribatid mite density. Similar to the correlation between mass of litter layer and oribatid mite density, soil pH also correlated with oribatid mite density, but the correlation was negative. Presumably, soil acidity does not directly affect oribatid mite densities, but via controlling the density of macro-decomposers in particular earthworms. As documented previously (Maraun and Scheu 2000; Migge-Kleian et al. 2006) oribatid mites also reach high densities in base-rich soils not colonized by earthworms indicating that the presence of earthworms reduces the density of oribatid mites. This scenario suggests that via soil $\mathrm{pH}$ parent rock affects colonization of earthworms (and other macro-decomposers) which in turn affects the thickness of the litter layer which eventually influences the density of oribatid mites (and other mesofauna; cf. Eisenhauer 2010). The litter layer is essential for oribatid mites as it functions both as habitat and as food resource (Ponge 1991; Schneider et al. 2004).

Oribatid mite densities were negatively correlated with the concentration of nitrogen in litter and fine roots. Again, this might be due to high densities of macro-decomposers at those nitrogen-rich sites. As parent rock, litter quality essentially drives the density of macrodecomposers including earthworms (Scheu et al. 2003; Salamon et al. 2005). Hence, by favoring macrodecomposers high quality litter may result in shallow litter layers; indeed, in the present study the mass of litter layer correlated negatively with concentrations of nitrogen in the litter and fine roots. 
Oribatid mite densities were positively correlated with the concentration of carbon in soil. Apart from feeding on litter material and microorganisms living therein oribatid mites also acquire resources from the soil (Albers et al. 2006; Pollierer et al. 2007). A high proportion of carbon in soil, which may have originated from root exudates which in turn have supported the growth of fungi (Frey et al. 2003; Butenschoen et al. 2007; Broeckling et al. 2008), may have fostered fungal feeding oribatid mites.

Unexpectedly, oribatid mite densities did not differ significantly between the three regions (Swabian Alb, Hainich, Schorfheide). This indicates that regional factors, such as precipitation, altitude and temperature, which differ between the regions (Fischer et al. 2010), affect oribatid mite densities less than forest type.

The proportion of juvenile oribatid mites was highest in the Schorfheide. This is likely due to the high number of parthenogenetic species of the taxon Desmonomata (e.g., Nothrus sylvestris and Nanhermannia nana) in the Schorfheide. Those species develop slowly and have generation times of several years (Norton and Palmer 1991). Due to their slow development juvenile Desmonomata are present in high numbers throughout the year.

\subsection{Oribatid mite diversity}

Oribatid mite diversity varied little with forest type and region. Only in the coniferous forests in the Swabian Alb oribatid mite diversity was somewhat higher than in the $70 \mathrm{y}$ old and unmanaged beech forests of the Schorfheide. Previous studies also found oribatid mite diversity to be little affected by forest stand age (Zaitsev et al. 2002) or tree species (Migge et al. 1998; Sylvain and Buddle 2010). The somewhat higher diversity of oribatid mites in the coniferous forests at the Swabian Alb might be related to planting spruce trees on base rich Cambisols, which may have increased the number of niches. The low species number in the 70 $y$ old unmanaged beech forests of the Schorfheide may at least in part result from the high density of Brachychthoniidae and Suctobelbidae which were not determined to species level.

The diversity of oribatid mites and factors affecting it are still little understood (Anderson 1978; Hansen 2000; Maraun et al. 2003). Results of the present study suggest that the number of (trophic) niches of oribatid mites in beech and coniferous forests in Central European forests is similar and little affected by forest management and forest type. The limited effect of forest management and forest type on soil living oribatid mite diversity contrasts strong effects on above ground organisms (Paillet et al. 2010). These differential effects deserve further attention. 


\subsection{Oribatid mite community structure}

Oribatid mite community composition differed between the coniferous and beech forests and between the young (30 y old) and the old (natural) beech forests. This suggests that the different forest types provide different niches for oribatid mites. Different niches are likely to be related to oribatid mite nutrition. It has been shown using a number of methods that oribatid mite species occupy very different trophic niches (Maraun et al. 2011; Schneider et al. 2004; Koukol et al. 2009; Heidemann et al. 2011).

Oribatid mite community structure in the beech forests changed gradually from the $30 \mathrm{y}$ old over the $70 \mathrm{y}$ old to the natural beech forests pointing to a slow but constant species turnover with ageing of the beech forests. This slow succession may be due to a parallel slow change in fungal and bacterial community structure (Visser 1995; Pennanen et al. 1999), but also in changes in the colonization by soil macrofauna (Scheu et al. 2003; Crow et al. 2009).

Oribatid mite communities differed significantly between each of the three Exploratories. Although oribatid mites are poor dispersers (Berthet 1964; Ojala and Huhta 2001; Lehmitz et al. 2011) dispersal limitation is unlikely to be responsible for these differences as most oribatid mite species are widespread and have a palaearctic or holarctic distribution (Weigmann 2006). The clear differences in oribatid mite community structure between the three regions point to the existence of different niches in the respective systems. Oribatid mite community structure can be predicted (Maraun and Scheu 2000) indicating that these communities do not assemble by chance which supports the importance of different niches for the community structure of oribatid mites. However, the factors responsible for these different oribatid mite communities in the respective forests are still little understood.

The oribatid mite communities of the four forest types within the investigated regions were more similar to each other than between regions. This points to the importance of regional factors, such as temperature, precipitation and parent rock, being more important as structuring forces for oribatid mite communities than forest types. Studying oribatid mite assemblages in forests of different harvesting regimes at local and regional scales Déchêne and Buddle (2009) also suggested regional factors to be superior to local factors.

As indicated by CCA soil acidity was the most important environmental factor for oribatid mite communities. However, soil acidity unlikely affects oribatid mite communities directly since most oribatid mite species tolerate even very acidic conditions (Hagvar 1990). Rather, as discussed above, soil pH affects colonization of the forests by soil macro-decomposers and this affects oribatid mites via changes in the thickness of the litter layer. Further, soil pH affects soil 
microorganisms (Baath and Anderson 2003; Dequiedt et al. 2011) which also is likely to affect oribatid mites.

\subsection{Conclusions}

Overall, oribatid mite density varied significantly with forest type, whereas the diversity and community structure of oribatid mites was little affected. The most important factor for oribatid mite density was mass of litter layer being at a maximum in coniferous forests and at a minimum in old-growth natural beech forests. This indicates that forest types changing the thickness of the litter layer and strongly affect oribatid mite densities. Among abiotic factors, soil acidity strongly affects oribatid mite community structure but this is likely due to indirect effects via affecting macro-decomposers, in particular earthworms, which detrimentally affect oribatid mites via bioturbation i.e., by reducing the thickness of organic layers and by mixing litter and mineral soil. Generally, variations in oribatid mite community structure were more pronounced at the regional scale (between the three regions), than at the local scale between forest types (within the regions).

\section{Acknowledgements}

The work has been funded by the DFG Priority Program 1374 "Biodiversity Exploratories" (BR 2315/7-1). Field work permits were given by the responsible state environmental offices of Baden-Württemberg, Thüringen and Brandenburg (according to $\S 72$ BbgNatSchG). We thank Ulrich Brose, Roswitha Ehnes, Bernhard Eitzinger, Bernhard Klarner, Melanie Maraun and Gregor Kalinkat for assistance in field work, Christel Fischer for help during sample processing, Simone Cesarz for helpful comments on an earlier version of the manuscript and the management team of the "Biodiversity Exploratories" for support of field work and provision of infrastructure. 


\section{References}

Albers, D., Schaefer, M., Scheu, S. (2006) Incorporation of plant carbon into the soil animal food web of an arable system. Ecology 87, 235-245.

Anderson, J.M. (1975) Succession diversity and trophic relationships of some soil animals in decomposing leaf litter. Journal of Animal Ecology 44, 475-495.

Anderson, J.M. (1978) Inter-habitat and intra-habitat relationships between woodland Cryptostigmata species-diversity and diversity of soil and litter microhabitats. Oecologia 32, 341-348.

Baath, E., Anderson, T.H. (2003) Comparison of soil fungal/bacterial ratios in a pH gradient using physiological and PLFA-based techniques. Soil Biology \& Biochemistry 35, 955-963.

Berthet, P.L. (1964) Field-study of the mobility of Oribatei (Acari) using radioactive tagging. Journal of Animal Ecology 33, 443-449.

Braak, C.J.F. ter, Šmilauer, P. (2002) CANOCO Reference Manual and CanoDraw for Windows User's Guide: Software for Canonical Community Ordination (version 4.5). Microcomputer Power Ithaca, New York.

Brennan, K.E.C., Ashby, L., Majer, J.D., Moir, M.L., Koch, J.M. (2006) Simplifying assessment of forest management practices for invertebrates: How effective are higher taxon and habitat surrogates for spiders following prescribed burning? Forest Ecology and Management 231, 138154.

Broeckling, C.D., Broz, A.K., Bergelson, J., Manter, D.K., Vivanco, J.M. (2008) Root exudates regulate soil fungal community composition and diversity. Applied and Environmental Microbiology 74, 738-744.

Butenschoen, O., Poll, C., Langel, R., Kandeler, E., Marhan, S., Scheu, S. (2007) Endogeic earthworms alter carbon translocation by fungi at the soil-litter interface. Soil Biology \& Biochemistry 39, 2854-2864.

Cassagne, N., Gauquelin, T., Bal-Serin, M.C., Gers, C. (2006) Endemic Collembola privileged bioindicators of forest management. Pedobiologia 50, 127-134.

Crow, S.E., Filley, T.R., McCormick, M., Szlavecz, K., Scott, D.E., Gamblin, D., Conyers, G. (2009) Earthworms stand age and species composition interact to influence particulate organic matter chemistry during forest succession. Biogeochemistry 92, 61-82.

Déchêne, A.D., Buddle, C.M. (2009) Effects of experimental forest harvesting on oribatid mite biodiversity. Forest Ecology and Management 258, 1331-1341.

Dequiedt, S., Saby, N.P.A., Lelievre, M., Jolivet, C., Thioulouse, J., Toutain, B., Arrouays, D., Bispo, A., Lemanceau, P., Ranjard, L. (2011) Biogeographical patterns of soil molecular microbial biomass as influenced by soil characteristics and management. Global Ecology and Biogeography 20, 641-652.

Eisenhauer, N. (2010) The action of an animal ecosystem engineer: Identification of the main mechanisms of earthworm impacts on soil microarthropods. Pedobiologia 53, 343-352.

Ellenberg, H. (1996) Vegetation Mitteleuropas mit den Alpen, 5th edition. Ulmer, Stuttgart.

Erdmann, G., Otte, V., Langel, R., Scheu, S., Maraun, M. (2007) The trophic structure of bark-living oribatid mite communities analyzed with stable isotopes ( $\mathrm{N}-15 \mathrm{C}-13$ ) indicates strong niche differentiation. Experimental \& Applied Acarology 41, 1-10.

European Environment Agency (2005) Vulnerability and Adaptation to Climate Change in Europe. Technical Report 7/2005. Office for Official Publications of the European Communities, Luxembourg. 
Fischer, M., Bossdorf, O., Gockel, S., Haensel F., Hemp, A., Hessenmoeller, D., Korte, G., Nieschulze, J., Pfeiffer, S., Prati, D., Renner, S., Schoening, I., Schumacher, U., Wells, K., Buscot, F., Kalko, E.K.V., Linsenmair, K.E., Schulze, E.D., Weisser, W.W. (2010) Implementing large-scale and longterm functional biodiversity research: The Biodiversity Exploratories. Basic and Applied Ecology $11,473-485$.

Frey, S.D., Six, J., Elliott, E.T. (2003) Reciprocal transfer of carbon and nitrogen by decomposer fungi at the soil-litter interface. Soil Biology \& Biochemistry 35, 1001-1004.

Giller, P.S. (1996) The diversity of soil communities, the 'poor man's tropical rainforest'. Biodiversity and Conservation 5, 135-168.

Hagvar, S. (1990) Reactions to soil acidification in microarthropods - is competition a key factor? Biology and Fertility of Soils 9, 178-181.

Halpern, C.B., Spies, T.A. (1995) Plant-species diversity in natural and managed forests of the Pacific-Northwest. Ecological Applications 5, 913-934.

Hansen, R.A. (2000) Effects of habitat complexity and composition on a diverse litter microarthropod assemblage. Ecology 81, 1120-1132.

Heidemann, K., Scheu, S., Ruess, L., Maraun, M. (2011) Molecular detection of nematode predation and scavenging in oribatid mites: Laboratory and field experiments. Soil Biology \& Biochemistry 43, 2229-2236.

Jongman, R.H.G., Braak, C.J.F. ter, van Tongeren, O.F.R. (1995) Data analysis in community and landscape ecology. Cambridge University Press, Cambridge.

Koukol, O., Mourek, J., Janovsky, Z., Cerna, K. (2009) Do oribatid mites (Acari: Oribatida) show a higher preference for ubiquitous vs. specialized saprotrophic fungi from pine litter? Soil Biology \& Biochemistry 41, 1124-1131.

Lehmitz, R., Russell, D., Hohberg, K., Christian, A., Xylander, W.E.R. (2011) Wind dispersal of oribatid mites as a mode of migration. Pedobiologia 54, 201-207.

Lindo, Z., Visser, S. (2004) Forest floor microarthropod abundance and oribatid mite (Acari: Oribatida) composition following partial and clear-cut harvesting in the mixedwood boreal forest. Canadian Journal of Forest Research 34, 998-1006.

Maraun, M., Scheu, S. (2000) The structure of oribatid mite communities (Acari Oribatida): patterns mechanisms and implications for future research. Ecography 23, 374-383.

Maraun, M., Martens, H., Migge, S., Theenhaus, A., Scheu, S. (2003) Adding to 'the enigma of soil animal diversity': fungal feeders and saprophagous soil invertebrates prefer similar food substrates. European Journal of Soil Biology 39, 85-95.

Maraun, M., Erdmann, G., Fischer, B.M., Pollierer, M.M., Norton, R.A., Schneider, K., Scheu, S. (2011) Stable isotopes revisited: Their use and limits for oribatid mite trophic ecology. Soil Biology \& Biochemistry 43, 877-882.

Macfadyen, A. (1961) Improved funnel-type extractors for soil arthropods. Journal of Animal Ecology 30, 171-184.

Marshall, V.G. (2000) Impacts of forest harvesting on biological processes in northern forest soils. Forest Ecology and Management 133, 43-60.

Migge, S., Maraun, M., Scheu, S., Schaefer, M. (1998) The oribatid mite community (Acarina) of pure and mixed stands of beech (Fagus sylvatica) and spruce (Picea abies) of different age. Applied Soil Ecology 9, 115-121.

Migge-Kleian, S., Mclean, M.A., Maerz, J.C., Heneghan, L. (2006) The influence of invasive earthworms on indigenous fauna in ecosystems previously uninhabited by earthworms. Biological Invasions 8, 1275-1285. 
Niemelä, J., Haila, Y., Puntilla, P. (1996) The importance of small-scale heterogeneity in boreal forests: Variation in diversity in forest-floor invertebrates across the succession gradient. Ecography 19, 352-368.

Niemelä, J., Koivula, M., Kotze, D.J. (2007) The effects of forestry on carabid beetles (Coleoptera: Carabidae) in boreal forests. Journal of Insect Conservation 11, 5-18.

Norton, R.A., Palmer, S.C. (1991) The distribution mechanisms and evolutionary significance of parthenogenesis in oribatid mites. In: Schuster, R., Murphy, P.W. (eds.), The Acari: Reproduction Development and Life-History Strategies, pp 107-136. Chapman and Hall, London.

Norton, R.A., Behan-Pelletier, V. (2009) Suborder Oribatida. In: Krantz, G.W., Walter, D.E. (eds.), A Manual of Acarology, 3rd ed., pp. 430-564. Texas Tech University Press, Texas.

Ojala, R., Huhta, V. (2001) Dispersal of microarthropods in forest soil. Pedobiologia 45, 443-540.

Osler, G.H.R., Korycinska, A., Cole, L. (2006) Differences in litter mass change mite assemblage structure on a deciduous forest floor. Ecography 29, 811-818.

Paillet, Y., Bergés, L., Hjältén, J., Ódor, P., Avon, C., Bernhardt-Roemermann, M., Bijlsma, R.J., De Bruyn, L., Fuhr, M., Grandin, U., Kanka, R., Lundin, L., Luque, S., Magura, T., Matesanz, S., Mészáros, I., Sebastiá, M.T., Schmidt, W., Standovár, T., Tóthmérész, B., Uotila, A., Valladares, F., Vellak, K., Virtanen, R. (2010) Biodiversity Differences between Managed and Unmanaged Forests: Meta-Analysis of Species Richness in Europe. Conservation Biology 24, 101-112.

Pennanen, T., Liski, J., Baath, E., Kitunen, V., Uotila, J., Westman, C.J., Fritze, H. (1999) Structure of the microbial communities in coniferous forest soils in relation to soil fertility and stand development stage. Microbial Ecology 38, 168-179.

Pollierer, M.M., Langel, R., Koerner, C., Maraun, M., Scheu, S. (2007) The underestimated importance of belowground carbon input for forest soil animal food webs. Ecology Letters 10, 729-736.

Ponge, J.F. (1991) Food resources and diets of soil animals in a small area of Scots pine litter. Geoderma 49, 33-62.

Salamon, J., Alphei, J., Ruf, A., Schaefer, M., Scheu, S., Schneider, K., Suehrig, A., Maraun, M. (2005) Transitory dynamic effects in the soil invertebrate community in a temperate deciduous forest: Effects of resource quality. Soil Biology \& Biochemistry 38, 209-221.

Schaefer, M., Schauermann, J. (1990) The soil fauna of beech forests - comparison between a mull and a moder soil. Pedobiologia 34, 299-314.

Schneider, K., Migge, S., Norton, R.A., Scheu, S., Langel, R., Reineking, A., Maraun, M. (2004) Trophic niche differentiation in soil microarthropods (Oribatida Acari): evidence from stable isotope ratios $\left({ }^{15} \mathrm{~N} /{ }^{14} \mathrm{~N}\right)$. Soil Biology \& Biochemistry 36, 1769-1774.

Scheu, S., Albers, D., Alphei, J. (2003) The soil fauna community in pure and mixed stands of beech and spruce of different age: trophic structure and structuring forces. Oikos 101, 225-238.

Sylvain, Z.A., Buddle, C.M. (2010) Effects of forest stand type on oribatid mite (Acari: Oribatida) assemblages in a southwestern Quebec forest. Pedobiologia 53, 321-325.

Tiunov, A.V., Scheu, S. (2000) Microfungal communities in soil litter and casts of Lumbricus terrestris L. (Lumbricidae): a laboratory experiment. Applied Soil Ecology 14, 17-26.

Visser, S. (1995) Ectomycorrhizal fungal succession in jack pine stands following wildfire. New Phytologist 129, 389-401.

Weigmann, G. (2006) Hornmilben (Oribatida). Goecke und Evers, Keltern.

Werner, S.M., Raffa, K.F. (2000) Effects of forest management practices on the diversity of groundoccurring beetles in mixed northern hardwood forests of the Great Lakes Region. Forest Ecology and Management 139, 135-155. 
Zaitsev, A.S., Chauvat, M., Pflug, A., Wolters, V. (2002) Oribatid mite diversity and community dynamics in a spruce chronosequence. Soil Biology \& Biochemistry 34, 1919-1927. 


\section{Appendix}

Achi_cole - Achipteria coleoptrata (Linné, 1758); Ador_ovat - Adoristes ovatus (C.L. Koch, 1839); Atro_stri - Atropacarus striculus (C.L. Koch, 1835); Bern_bica - Berniniella bicarinata (Paoli, 1908); Brach_sp. - Brachychthoniidae; Cara_laby - Carabodes labyrinthicus (Michael, 1879); Cara_orna - Carabodes ornatus, Storkan, 1925; Cera_grac - Ceratozetes gracilis (Michael, 1884); Cham_bore - Chamobates borealis (Trägardh, 1902); Cham_cusp Chamobates cuspidatus (Michael, 1884); Cham_subg - Chamobates subglobulus (Oudemans, 1900); Cham_voig - Chamobates voigtsi (Oudemans, 1902); Dama_ripa - Damaeus riparius Nicolet, 1855; Diss_orna - Dissorhina ornata (Oudemans, 1900); Enio_minu - Eniochthonius minutissimus (Berlese, 1903); Eulo_riba - Eulohmannia ribagai (Berlese, 1910); Eupe_hirt Eupelops hirtus (Berlese, 1916); Eupe_plic - Eupelops plicatus (C.L. Koch, 1835); Galu_lanc Galumna lanceata (Oudemans, 1900); Hypo_lute - Hypochthonius luteus Oudemans, 1917; Hypo_rufu - Hypochthonius rufulus C.L. Koch, 1835; Meta_pulv - Metabelba pulverosa Strenzke, 1953; Micr_mini - Microtritia minima (Berlese, 1904); Micr_minu - Microppia minus (Paoli, 1908); Nanh_nana - Nanhermannia nana (Nicolet, 1855); Noth_silv - Nothrus sylvestris Nicolet, 1855; Oppi_falc - Oppiella falcata (Paoli, 1908); Oppi_nova - Oppiella nova (Oudemans, 1902); Oppi_obso - Oppiella obsoleta (Paoli, 1908); Oppi_prop - Oppiella propinqua Mahunka \& Mahunka-Papp, 2000; Oppi_subp - Oppiella subpectinata (Oudemans, 1900); Orib_calc - Oribatella calcarata (C.L. Koch, 1835); Orib_tibi - Oribatula tibialis (Nicolet, 1855); Pant_paol - Pantelozetes paolii (Oudemans, 1913); Phth_comp - Phthiracarus compressus Jacot, 1930; Phth_glob - Phthiracarus globosus (C.L. Koch, 1841); Phth_laev Phthiracarus laevigatus (C.L. Koch, 1844); Phth_lent - Phthiracarus lentulus (C.L. Koch, 1841); Phth_long - Phthiracarus longulus (C.L. Koch, 1841); Plat_pelt - Platynothrus peltifer (C.L. Koch, 1839); Poro_spin - Porobelba spinosa (Sellnick, 1920); Quad_hamm - Quadroppia hammerae Minguez, Ruiz \& Subias, 1985); Quad_mons - Quadroppia monstruosa Hammer, 1979 (sensu Minguez, Ruiz \& Subias 1985); Quad_quad - Quadroppia quadricarinata (Michael, 1885); Rhys_dupl - Rhysotritia duplicata (Grandjean, 1953); Sche_init - Scheloribates initialis (Berlese, 1908); Steg_herc - Steganacarus herculeanus Willmann, 1953; Steg_magn Steganacarus magnus (Nicolet, 1855); Sucto_sp. - Suctobelbidae; Tect_alat - Tectocepheus velatus alatus Berlese, 1913; Tect_mino - Tectocepheus minor Berlese, 1903; Tect_sare Tectocepheus velatus sarekensis Trägardh, 1910; Tect_vela - Tectocepheus velatus velatus (Michael, 1880) 


\section{Chapter 4}

\section{Positive correlation between density and parthenogenetic reproduction in oribatid mites (Acari) supports the structured resource theory of sexual reproduction}

Maraun, M., Norton, R.A., Ehnes, R.B., Scheu, S., Erdmann, G.

published in:

Maraun, M., Norton, R.A., Ehnes, R.B., Scheu, S., Erdmann, G. (2012) Positive

Correlation between density and parthenogenetic reproduction in oribatid mites (Acari) supports the structured resource theory of sexual reproduction.

Evolutionary Ecology Research, 14, 311-323. 


\section{Abstract}

Question: A number of theories have been proposed to explain the dominance of sexual reproduction in Metazoa. Using oribatid mites (Acari, Oribatida) as model organisms, we test the validity of the 'Structured Resource Theory of Sexual Reproduction' (SRTS) which suggests that limited resources result in the dominance of sexual processes, whereas ample resources favour parthenogenesis. Oribatid mites are mainly soil living animals that reproduce either sexually or by thelytoky.

Key assumptions: Resource supply is reflected by animal density. Populations are controlled predominantly by bottom-up rather than top-down forces, such as predation, which is likely to be true for oribatid mites.

Data studied: The relationship between oribatid mite density and the frequency of parthenogenetic reproduction was investigated at two spatial scales (1) regionally using data on oribatid mites from two different forests in Germany, and (2) globally compiling data on 38 oribatid mite communities from different habitats.

Conclusions: Predictions of the SRTS were supported at both scales, indicating that ample resources (as indicated by high population densities) in fact favour parthenogenetic reproduction.

\section{Introduction}

The perceived disadvantages of sexual compared to parthenogenetic reproduction are manifold and include, for example, the break-up of favourable gene combinations and the need to both find mating partners and produce male offspring (Maynard Smith, 1978). Despite these disadvantages, most species of animals reproduce sexually (Bell, 1982). Theories proposed to explain advantages and disadvantages of parthenogenetic and sexual reproductive modes might be viewed as either genetic (based on mutations) or ecological (based on species - environment interactions, including those with other species). Mutational theories state that parthenogens either accumulate detrimental mutations (Kondrashov's hatchet; Kondrashov, 1988), or that in parthenogenetic populations mutation-free genotypes are more quickly lost than in sexual populations (Muller's ratchet; Muller, 1964). Another 
genetic theory assumes beneficial mutations to spread more quickly in sexual than parthenogenetic populations (Fisher-Muller-accelerated-evolution; Fisher, 1930; Muller, 1932). Ecological theories propose that strong biotic interactions foster sexual reproduction (Red Queen hypothesis; Jaenicke, 1978; Hamilton, 1980), or that spatially variable niches favor sexually produced offspring (Tangled Bank hypothesis; Ghiselin, 1974; Bell, 1982).

These different and mutually exclusive theories led some authors to propose that multiple theories are needed to explain the various aspects associated with sexual reproduction (West et al., 1999). However, the recent structured resource theory of sexual reproduction' (SRTS; Scheu and Drossel, 2007) proposes an overarching explanation, that sexual reproduction favors the exploitation of complex resources that are in short supply. According to the SRTS, outcrossing and mixing shuffle new genotypes, allowing a more complete exploitation of local resources. Conversely, it predicts that the availability of ample resources favours parthenogenetic reproduction since parthenogenetic species exploit these resources more quickly. The SRTS resembles the Tangled Bank theory in that it relates advantages of sexual reproduction to variations in niche space, but it focuses on food resources rather than on abiotic conditions (Song et al., 2011). Thus, the SRTS incorporates sib-competition models in which sexually produced offspring benefit from being genetically different by relaxing intraspecific competition (Williams, 1966, 1975; Bell, 1982). In addition, the SRTS integrates aspects of the Red Queen theory, since parasites may be experienced by the host as aggravation of shortage of resources (Scheu and Drossel, 2007). Whether or not the SRTS is sufficient to explain all evolutionary aspects of these issues, we believe that it is a powerful predictor of the local distribution of reproductive modes -that is, of the relative dominance of sexual and parthenogenetic reproduction in local communities. This idea is best tested in environments where parthenogenetic taxa are frequent and widespread, where we can assume that mechanisms promoting the general dominance of sexual reproduction are more relaxed.

Below-ground communities are ideally suited for investigating the relative merits of sexual and parthenogenetic reproduction, since parthenogenetic or asexual reproduction is common in protozoans, nematodes, enchytraeid worms, earthworms, collembolans, isopods and oribatid mites (Bell, 1982, 1988; Palmer and Norton, 1991; Christensen et al., 1992; Sbordoni et al., 1997; Doroszuk et al., 2006; Terhivuo and Saura, 2006; Chahartaghi et al., 2009; Fischer et al., 2010a). Sexual taxa are also common, and often co-exist with parthenogenetic taxa that are both closely related and ecologically similar. Thus understanding the high incidence of 
parthenogenetic reproduction in soil may help to identify unifying concepts responsible for the maintenance and general dominance of sexual reproduction.

Oribatid mites are among the most suited animal group for investigating mechanisms responsible for the maintenance of sexual reproduction in soil animal taxa. They are ubiquitous, occurring in high numbers in virtually all ecosystem (Maraun and Scheu, 2000). Of the approximately 10,000 species described today, nearly $10 \%$ reproduce by parthenogenetic development of females, i.e. by thelytoky (Palmer and Norton, 1991; Norton and Palmer, 1991; Norton, 1994), and parthenogenetic species can comprise up to $80 \%$ of oribatid mite individuals in local faunas (Fischer et al., 2010).

Using oribatid mites as model organisms, we tested the prediction of the SRTS that the proportion of parthenogenetic individuals is positively correlated with resource availability. The prediction was investigated at two spatial scales: regional (two forest systems in Germany) and global. Oribatid mite density was taken as a proxy for resource availability, since all current information shows that oribatid mites are controlled predominantly by bottom-up forces. Indeed, due to an array of defense mechanisms including strong cuticle, protective structures and body forms, and chemical repellants (Sanders and Norton, 2004; Heethoff et al., 2011) oribatid mites have been shown to be resistant to predation (Peschel et al., 2006).

Using density as a proxy for resource availability is too simplistic, as it ignores changes in metabolism with body size. Allometric scaling predicts that smaller organisms have higher metabolic rates per unit body mass (Brown et al., 2004) and reach higher densities than larger organisms (Damuth, 1981). Therefore, at the regional scale we also investigated the relationship of oribatid mite reproductive mode to metabolism (i.e. respiration). The respiration of oribatid mites has been estimated to be equivalent to $16 \%$ of the energy ingested (Luxton, 1975; Wallwork, 1983).

Our regional sites comprised mull (Swabian Alb) and moder forests (Schorfheide) varying in macrofaunal density (Schaefer and Schauermann, 1990). Soil macrofauna is known to affect mesofauna (including oribatid mite) communities through mechanical disturbance, resource competition, predation and destruction of habitable space (Maraun et al., 2003; Eisenhauer, 2010; Erdmann et al., 2012). Therefore, we expected the relationship between reproductive mode of oribatid mites and density and/or respiration to be most pronounced in the macrofauna-poor moder systems of the Schorfheide. On the global scale, we compiled data on the density of parthenogenetic oribatid mite species from 38 sites ranging from temperate and tropical forests, to fields and meadows, to the bark of trees. According to the SRTS, we 
expected the density of oribatid mites to be positively correlated with the frequency of parthenogenetic individuals in both datasets.

\section{Materials and Methods}

\subsection{Regional scale}

The sites of the regional dataset comprised forests in the southwest (Swabian Alb; 460-860 m a.s.I.) and the northeast (Schorfheide; 3-140 m a.s.I.) of Germany. They form part of the 'Biodiversity Exploratories', a long-term monitoring and experimental study project (Fischer et al., 2010b). The Swabian Alb is dominated by European beech (Fagus sylvatica) growing on Jurassic limestone parent rock; the sampled forest types were on cambisols or leptosols $\mathrm{pH}$ of $4.51 \pm 0.72$ ) at about $700 \mathrm{~m}$ above sea level. The Schorfheide is located on glacial till, which often is covered by sand; the accompanying soil types are mostly dystric cambisols $(\mathrm{pH} 3.3 \pm$ 0.19), but occasionally podsols occur (for details see Fischer et al., 2010b). Mean annual precipitation in the Swabian Alb is 700-1000 mm and in the Schorfheide $500-600 \mathrm{~mm}$, with a mean annual temperature of $6.0-7.0^{\circ} \mathrm{C}$ and $8.0-8.5^{\circ} \mathrm{C}$, respectively (Fischer et al., 2010b). Four forest types were studied in each region: 30-year-old beech forests, 70 -year-old beech forests, 120-year-old unmanaged beech forests and 70-year-old coniferous forests (consisting of Picea abies in the Swabian Alb and Pinus sylvestris in the Schorfheide).

In spring 2008, four soil samples were taken from each forest in each of the two regions. The 32 samples were taken with a corer $(5 \mathrm{~cm}$ diameter) each separated into organic (L/F material) and soil ( $4 \mathrm{~cm}$ thick) layers, from which soil arthropods were extracted by heat (Macfadyen, 1961); mite data from these two layers were subsequently pooled for all analyses. Adult oribatid mites were identified following Weigmann (2006) and the gender of each individual was determined by examining genitalia (Grandjean, 1955, 1956). Suctobelbidae and Brachychthoniidae were identified only to family level. The mode of reproduction (sexual or parthenogenetic) was inferred from sex ratios in combination with data in the literature (Palmer and Norton, 1991; Cianciolo and Norton, 2006).

For each species, fresh weight $(M)$ was calculated from dry weight (dryM) of individuals (Hadley, 1994) as $M=4 \times$ dry $M$ or from the mean body length $L[\mathrm{~mm}]$ given in Weigmann (2006) and the correlation constants $a$ and $b$ given in Huhta and Koskenniemi (1975) as log $M=$ $b \log L+a$, with $a=2.386$ and $b=2.519$. Respiration $I[\mathrm{~J} / \mathrm{h} /$ ind.] was calculated from fresh 
weight $M$ [mg] using a linear model (Brown et al., 2004, Downs et al., 2008). The values $i_{0}, a$ and $E$ are specific for oribatid mites and were adopted from Ehnes et al. (2011):

$$
I=i_{0} M^{a} e^{\frac{-E}{k T}}
$$

with the normalization constant $\mathrm{i}_{0}=\mathrm{e}^{22.02277} \mathrm{~J} / \mathrm{h} / \mathrm{mg}$, the allometric exponent $\mathrm{a}=0.6793706$, the activation energy $\mathrm{E}=0.7060855 \mathrm{eV}$, the Boltzmann's constant $\mathrm{k}=8.62 * 10^{-5} \mathrm{eV} / \mathrm{K}$ and $\mathrm{T}=$ mean annual temperature (Swabian Alb $=279.7 \mathrm{~K}$; Schorfheide $=281.4 \mathrm{~K}$ ).

The calculated respiration per individual was multiplied by the density per square meter of each species; summing the respiration rates of all species present per square meter resulted in an estimate of the energy use of the whole oribatid mite community $\left[\mathrm{J} / \mathrm{h} / \mathrm{m}^{2}\right]$.

\subsection{Global scale}

The 38 sites investigated included a wide range of habitats: raw humus forests, moder forests, mull forests, riparian forests, peat bogs, meadows, fields, and lichen patches on the bark of trees (for details see Table 1; for references see Appendix). Most habitats were from temperate regions but we also included tropical forest sites. Sites strongly influenced by man such as agricultural systems were not included, as in such systems oribatid mites are unlikely to be controlled by resource availability.

\subsection{Statistical analysis}

The data (oribatid mite density, respiration, proportion of parthenogenetic individuals, and the respective residuals) were inspected using Kolmogorov-Smirnov test. Data were normally distributed $(p>0.2)$. For the regional scale dataset, the relationships between the proportion of parthenogenetic individuals and oribatid mite density, oribatid mite respiration and site (Schorfheide and Swabian Alb) were examined using stepwise linear regression. Similarly, for the global scale dataset, the relationships between the proportion of parthenogenetic individuals or taxa and oribatid mite density or habitat type (the seven different habitats where the oribatid mites were collected; see Table 1) were examined with stepwise linear regression. Prior to the analysis data on the proportion of parthenogenetic individuals and taxa were arcsin square-root transformed. Regressions between the proportion of parthenogenetic individuals and oribatid mite density were calculated with untransformed and log-transformed data; only results of the latter are presented as the logarithmic regression explained more variation in the dataset. Statistical analyses were carried out using STATISTICA v.9 (StatSoft Inc., Tulsa, Ok) and SAS 9.13 (SAS Institute Inc., Cary, NC). 
Tab. 1 Habitat type, site characteristics, soil type (if known), country of the study site, oribatid mite abundance (ind. $/ \mathrm{m}^{2}$ ), percentage of parthenogenetic individuals of oribatid mites, percentage of parthenogenetic taxa of oribatid mites, and references for the 38 sites used for the meta-analysis of this study (for the references see Appendix)

\begin{tabular}{|c|c|c|c|c|c|c|c|c|}
\hline $\begin{array}{l}\text { Site } \\
\text { no. }\end{array}$ & $\begin{array}{l}\text { habitat } \\
\text { type }\end{array}$ & $\begin{array}{l}\text { site } \\
\text { characteristics }\end{array}$ & $\begin{array}{l}\text { humus } \\
\text { form } \\
\text { (if known) }\end{array}$ & $\begin{array}{l}\text { country } \\
\text { of study }\end{array}$ & $\begin{array}{l}\text { abundance } \\
\text { (ind./m²) }\end{array}$ & $\begin{array}{l}\text { \% parthen. } \\
\text { individuals }\end{array}$ & $\begin{array}{c}\text { \% parthen. } \\
\text { taxa }\end{array}$ & publication \\
\hline 1 & bark & $\begin{array}{l}\text { Western } \\
\text { redcedar } \\
\text { trees (Thuja } \\
\text { plicata) }\end{array}$ & & Canada & 323 & 27 & 18 & $\begin{array}{l}\text { Lindo and Winchester } \\
\text { (2007) }\end{array}$ \\
\hline 2 & meadow & $\begin{array}{l}\text { brown earth } \\
\text { on loess }\end{array}$ & & Germany & 1482 & 8 & 27 & Toschki (2008) \\
\hline 3 & bark & $\begin{array}{l}\text { oak trees } \\
\text { (Quercus } \\
\text { robur) }\end{array}$ & & Germany & 1940 & 2 & 13 & Woltemade (1982) \\
\hline 4 & bark & $\begin{array}{l}\text { lime trees } \\
\text { (Tilia cordata) }\end{array}$ & & Germany & 5000 & 1 & 19 & $\begin{array}{l}\text { Weigmann and Jung } \\
\text { (1992) }\end{array}$ \\
\hline 5 & forest soil & $\begin{array}{l}\text { tropical } \\
\text { montane } \\
\text { rainforest } \\
(3000 \mathrm{~m}) \\
\text { oak trees }\end{array}$ & $\begin{array}{l}\text { raw } \\
\text { humus }\end{array}$ & Ecuador & 5769 & 4 & 17 & Eissfeller (2007) \\
\hline 6 & bark & $\begin{array}{l}\text { (Quercus } \\
\text { robur) }\end{array}$ & & Poland & 6000 & 2 & 15 & Erdmann (2004) \\
\hline 7 & forest soil & $\begin{array}{l}\text { tropical } \\
\text { montane } \\
\text { rainforest } \\
(3000 \mathrm{~m})\end{array}$ & $\begin{array}{l}\text { raw } \\
\text { humus }\end{array}$ & Ecuador & 6004 & 25 & 18 & Fronszek (2010) \\
\hline 8 & field & $\begin{array}{l}\text { brown earth } \\
\text { on loess }\end{array}$ & & Germany & 6179 & 23 & 35 & $\begin{array}{l}\text { Hülsmann and Wolters } \\
\text { (1998) }\end{array}$ \\
\hline 9 & forest soil & $\begin{array}{l}\text { beech forest } \\
\text { (Carpathians) }\end{array}$ & mull & Romania & 9200 & 6 & 21 & Fabian (1997) \\
\hline 10 & $\begin{array}{l}\text { riverine } \\
\text { forest }\end{array}$ & $\begin{array}{l}\text { sandy soils } \\
\text { with mainly } \\
\text { grey alder } \\
\text { (Alnus incana) }\end{array}$ & & Austria & 11100 & 17 & 13 & $\begin{array}{l}\text { Totschnig and Schatz } \\
\text { (1997) }\end{array}$ \\
\hline 11 & peat bog & $\begin{array}{l}\text { Ledo- } \\
\text { Spagnetum } \\
\text { with } \\
\text { Calamagrostis } \\
\text { stricta }\end{array}$ & mor & Germany & 12200 & 43 & 35 & Kehl (1997) \\
\hline 12 & forest soil & $\begin{array}{l}\text { tropical } \\
\text { montane } \\
\text { rainforest } \\
(1000 \mathrm{~m})\end{array}$ & moder & Ecuador & 13677 & 43 & 31 & Fronszek (2010) \\
\hline 13 & forest soil & $\begin{array}{l}\text { tropical } \\
\text { montane } \\
\text { rainforest } \\
(1000 \mathrm{~m})\end{array}$ & moder & Ecuador & 15015 & 36 & 35 & Eissfeller (2007) \\
\hline 14 & forest soil & $\begin{array}{l}\text { beech forest } \\
\text { on limestone }\end{array}$ & mull & Germany & 22134 & 36 & 44 & Schulz (1991) \\
\hline 15 & lichens & $\begin{array}{l}\text { on limestone } \\
\text { walls }\end{array}$ & & Sweden & 23500 & 24 & 50 & Fröberg et al. (2003) \\
\hline 16 & forest soil & beech forest & mull & Denmark & 34515 & 38 & 40 & Luxton (1981) \\
\hline 17 & forest soil & beech forest & mull & Germany & 40373 & 19 & 23 & Alberti (1996) \\
\hline
\end{tabular}




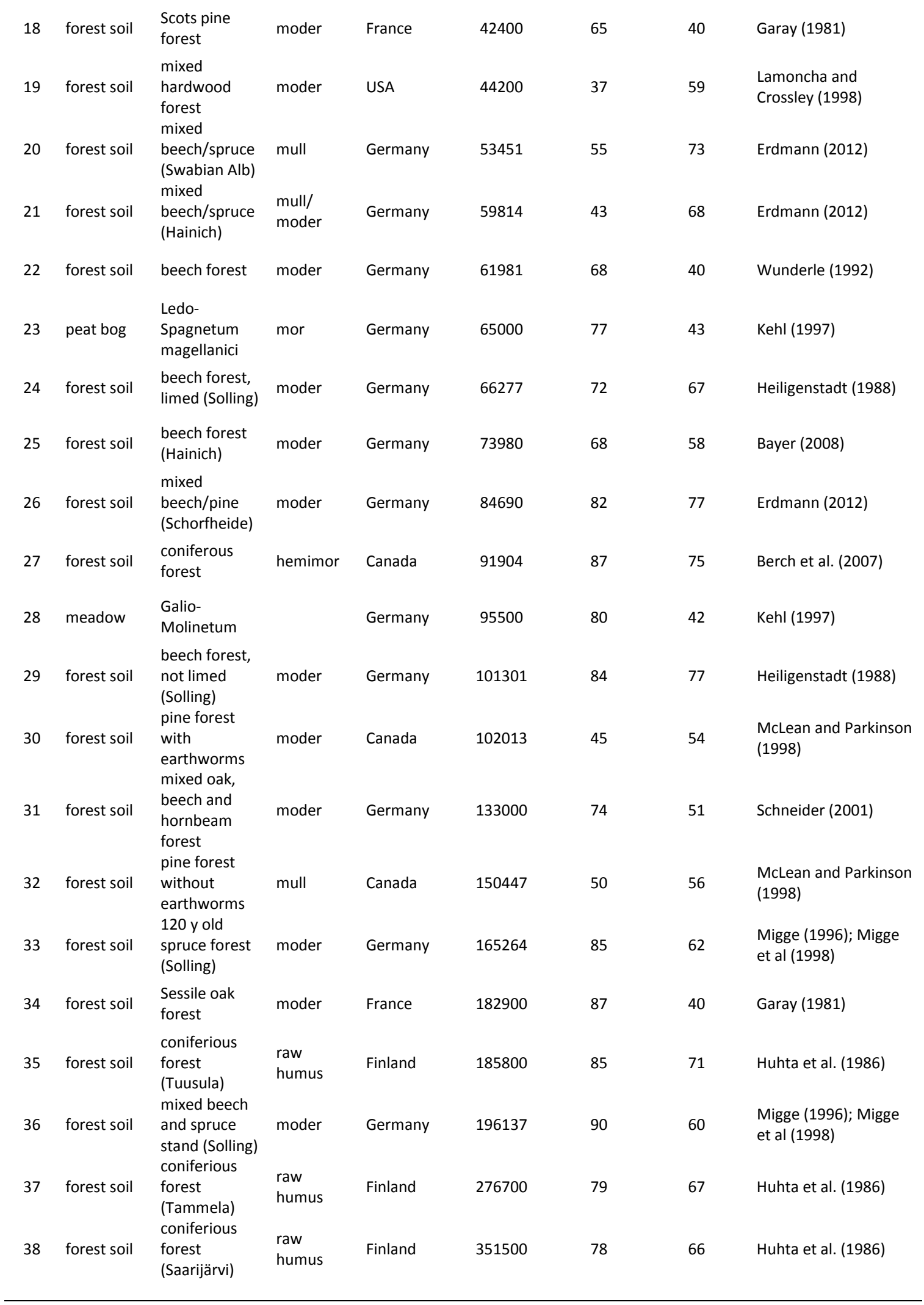




\section{Results}

\subsection{Regional scale}

There were more parthenogenetic individuals in the Schorfheide than in the Swabian Alb (stepwise linear regression; $r^{2}=0.65, F_{2,29}=56.24, p<0.0001$ ). Furthermore, the proportion of parthenogenetic individuals correlated positively with oribatid mite density $\left(r^{2}=0.76\right.$, $\left.F_{2,29}=14.82, p=0.0006\right)$ which was significant in the Schorfheide $\left(r^{2}=0.37, F_{1,14}=8.12, p=0.013\right)$ and marginally significant in the Swabian Alb $\left(r^{2}=0.21, F_{1,14}=3.72, p=0.074\right)$ (Fig. 1a). The proportion of parthenogenetic individuals also correlated positively with community respiration of oribatid mites (Fig. 1b) which was significant in the Schorfheide $\left(r^{2}=0.25\right.$, $\left.F_{1,14}=4.68, p=0.048\right)$ but not in the Swabian Alb $\left(r^{2}=0.17, F_{1,14}=2.92, p=0.109\right)$. However, including community respiration did not markedly increase the explained variance in the stepwise regression analysis, which was due to the high correlation between oribatid mite density and community respiration $\left(r^{2}=0.85\right)$. 

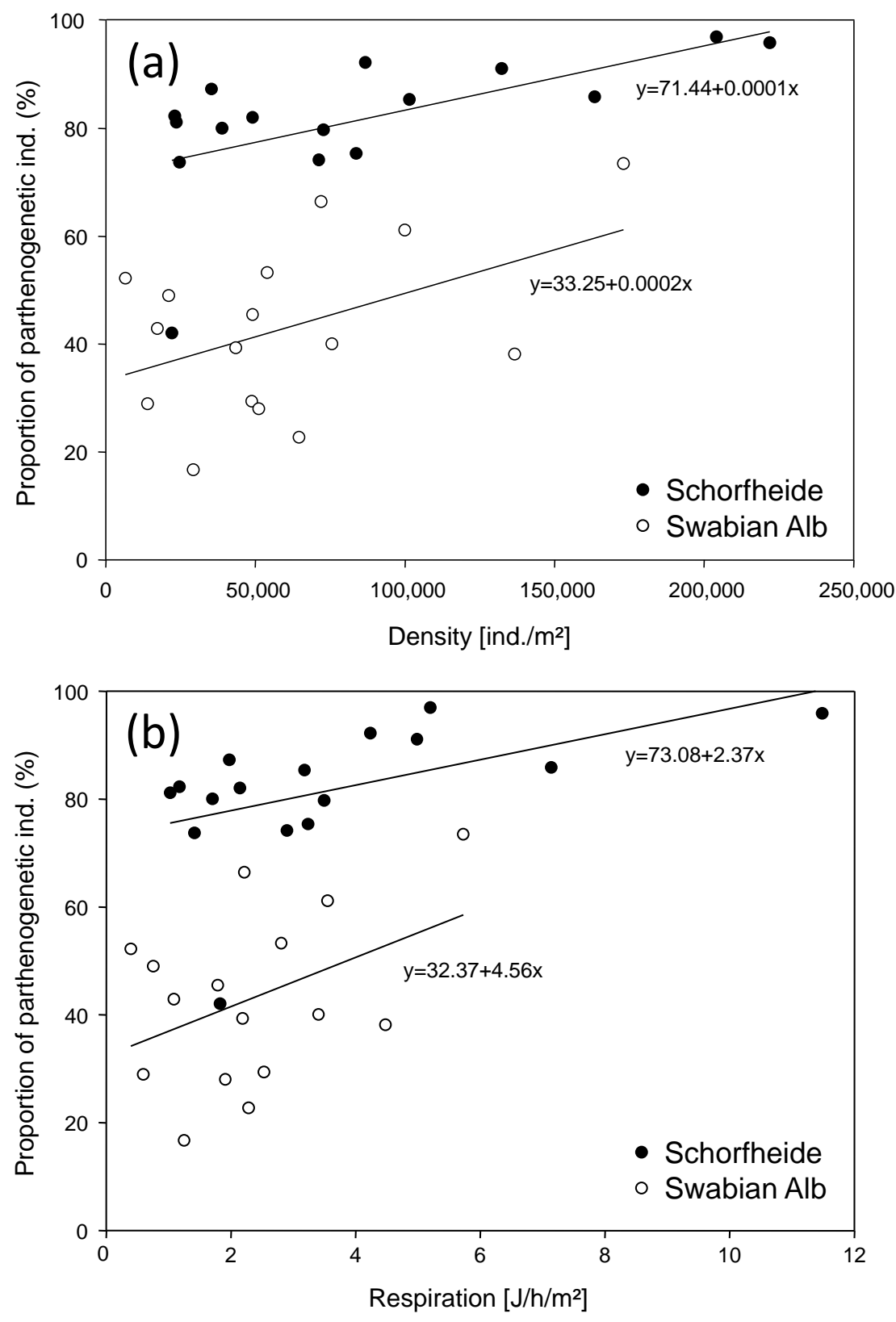

Fig. 1 Relationship between the proportion of parthenogenetic individuals and oribatid mite density (a) and oribatid mite respiration (b) in Swabian Alb and Schorfheide.

\subsection{Global scale}

The density of oribatid mites was significantly positively correlated with the percentage of parthenogenetic species and also with the percentage of parthenogenetic individuals (stepwise linear regression with log-transformed data; $r^{2}=0.61, F_{1,36}=57.93, p<0.0001$, and $r^{2}=0.66, F_{1,36}=72.90, p<0.0001$, respectively) (Fig. 2). Including habitat type did not increase the explained variance significantly. 


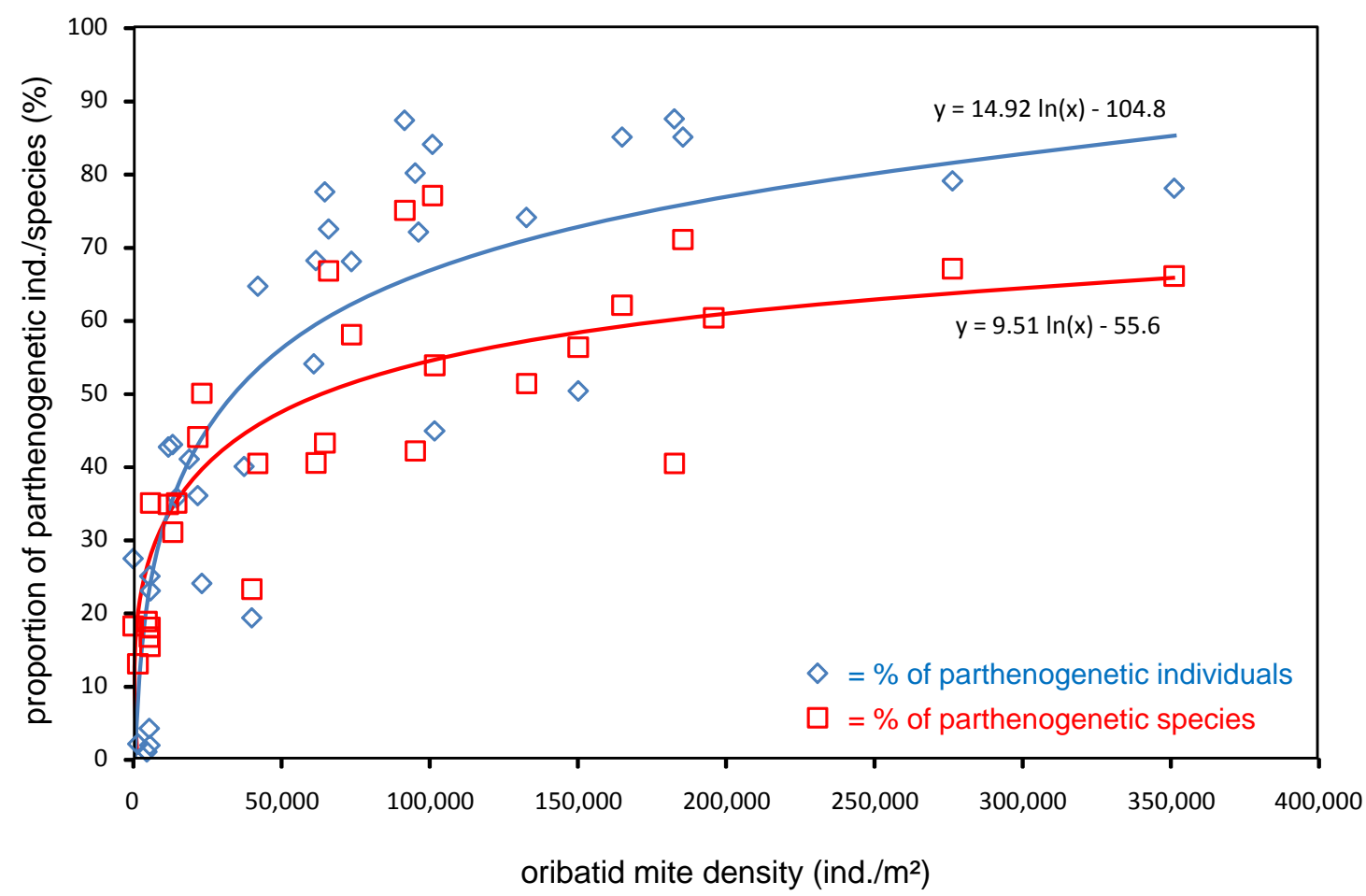

Fig. 2 Relationship between the proportion of parthenogenetic individuals/proportion of parthenogenetic species and oribatid mite density on a global scale. For details see text

\section{Discussion}

\subsection{Parthenogenetic reproduction in oribatid mites}

Results of our study suggest that the percentage of parthenogenetic individuals in oribatid mite communities is positively correlated with density, at both the regional and the global scale. The relationship also holds for metabolism as indicated by our regional scale dataset. Assuming that density and metabolism reflect the availability of resources, these relationships are consistent with predictions of the SRTS (Scheu and Drossel, 2007; Song et al., 2011). Oribatid mites were considered especially well-suited to test predictions of the SRTS, as they are little affected by top-down forces and therefore their density likely reflects resource availability (Schneider and Maraun, 2009; Heethoff et al., 2011). Although this may apply less strictly to soil invertebrates that are more subject to predation (Salamon et al., 2006; Schneider and Maraun, 2009), it would be interesting to investigate correlations between density and reproductive mode in a large range of soil invertebrate taxa, including in particular nematodes and collembolans. 


\subsection{Regional scale}

Irrespective of the indicator of the resources available to oribatid mite communities (density or respiration), or of the soil type at the two sites (mull or moder) the proportion of individuals of parthenogenetic oribatid mite species correlated positively with the resource proxy. However, the correlation was weaker in mull (Swabian Alb) than in the moder forests (Schorfheide) and less strong for respiration than for density.

The mull and moder forests studied differed both in the proportion of individuals of parthenogenetic oribatid mite species and in oribatid mite density ( $43 \%$ vs. $82 \%$ and 59,800 vs. 84,700 individuals per $\mathrm{m}^{2}$, respectively). The lower proportion of individuals of parthenogenetic species in the mull forests of the Swabian Alb, where oribatid mite density was lower, conforms to our expectations and is consistent with predictions of the SRTS. However, differences in habitat characteristics may also have contributed to the lower proportion of individuals of parthenogenetic oribatid mite species, since at this site the parthenogenetic Brachychthoniidae were rare. Low abundance of Brachychthoniidae is typical for mull forests and is likely to be due to disturbances by earthworms (Maraun and Scheu, 2000; Eisenhauer 2010). Macrofauna activity, in particular that of earthworms, has a detrimental effect on mesofauna communities, including those of the slow-developing longlived oribatid mites, weakening bottom-up control via resource availability.

\subsection{Global scale}

On the global scale, the proportion of parthenogenetic taxa (as well as parthenogenetic individuals) fitted best with density on a logarithmic scale. This reflects the high proportion (typically $>60 \%$ ) of parthenogenetic taxa in temperate and boreal forests where the density of oribatid mites spans a wide range from moderate to high (Behan-Pelletier, 1999). The shape of the curve further shows that the high incidence of parthenogenetic species (and individuals) in temperate forests is in contrast with that elsewhere, where parthenogenetic species are much less abundant, such as tropical forests, meadows and the bark of trees. According to the SRTS, the high proportion of parthenogenetic oribatid mites in temperate forests should be due to high availability of resources. Both above- and belowground inputs of resources (i.e. leaf litter and root derived resources) are likely to contribute to this high resource pool (Pollierer et al., 2007). Low densities of oribatid mites in tropical systems are probably related to poor litter quality; indeed, it is increasingly recognized that, compared with temperate and boreal forests, litter in tropical forests decomposes slowly (Haettenschwiler et al., 2011). This is consistent with the finding that tropical forests lack true decomposer animal taxa (Illig et al., 2005). The 
low density of oribatid mites on the bark of trees (and associated high proportion of sexual species) presumably relates to the fact that many bark-living oribatid mites feed on lichens which are well defended by secondary compounds (Fischer et al., 2010a).

Overall, the results indicate a somewhat counterintuitive interrelationship, i.e., with increasing oribatid mite density the importance of resource limitation declines. Presumably, in temperate and boreal forests oribatid mites are structured predominantly by densityindependent factors such as cold winters but also by pulsed resource inputs via litter and root deposits. In contrast, in habitats where sexual reproduction of oribatid mites dominates, i.e., on the bark of trees and in soil of tropical forests, resources likely are limiting. Again this is counterintuitive, as animal communities on the bark of trees are exposed to harsh environmental conditions, suggesting that bark living communities are structured by density independent factors. In fact, oribatid mites are well adapted to cold winter conditions and, by feeding predominantly on lichens, presumably are regulated by the availability of food resources that are well defended (e.g., by producing secondary compounds such as usnic acid) (Seyd and Seaward, 1984). Also, the low density of oribatid mites in tropical forest soils suggests a predominance of resource control, reflecting that tropical soils are poor in nutrients and leaves of tropical trees are of low food quality. Low densities of oribatid mites on the bark of trees and in tropical forests therefore also are conform to the predictions of the SRTS.

\subsection{The structured resource theory of sexual reproduction as an integrative theory}

Compared with other theories that attempt to explain the predominance of sexually reproducing species, the SRTS focuses on resource availability as the main factor responsible for the mode of reproduction (Scheu and Drossel, 2007; Song et al., 2011). Results of the present study support this view by providing evidence that oribatid mite communities of low density and with a high proportion of sexual species are controlled predominantly by densitydependent factors (i.e. the availability of food resources). In contrast, resources presumably are of limited importance as regulating factor of oribatid mite populations in soils of temperate and boreal forests where they reach high densities and where parthenogenetic species and individuals prevail. We propose that these somewhat counterintuitive relationships explain one of the most striking patterns in oribatid mite ecology, i.e., the dominance of parthenogens in certain ecosystems, such as temperate and boreal forests. This view is consistent with the assumption that the reproductive mode in oribatid mites is not controlled by biotic interactions (Cianciolo and Norton, 2006). 
Overall, both the regional and global scale datasets analyzed in this study are consistent with predictions of the SRTS, suggesting that the high incidence of parthenogenetic reproduction in soil animal taxa is related to periods of relaxed resource competition allowing parthenogenetic taxa to outgrow sexual ones. Experiments manipulating the resource supply of soil animal communities are needed to prove these conclusions. Soil animal communities are well suited for such experiments, as many parthenogenetic species of different taxonomic affiliation co-exist on small spatial scales, allowing tests of the generality of the SRTS in explaining sexual versus parthenogenetic reproduction in Metazoa.

\section{Acknowledgements}

We are grateful to Björn Rall for statistical advice, and to Derek Roff for helpful comments and suggestions. The work was funded by the DFG Priority Program 1374 "Biodiversity Exploratories" (BR 2315/7-1). Fieldwork permits were granted by the responsible state environmental offices of Baden-Württemberg and Brandenburg (according to $\S 72$ BbgNatSchG).

\section{References}

Behan-Pelletier, V.M. (1999) Oribatid mite fauna of northern ecosystems: a product of evolutionary adaptations or physical constraints? In: Needham, G.R., Mitchell, R., Horn, D.J., Welbourn, W.C. (eds.), Acarology IX Symposia. Ohio Biological Survey, pp. 87-105. Columbus, Ohio.

Bell, G. (1982) The Masterpiece of Nature: The Evolution and Genetics of Sexuality. University of California Press, Berkeley, California.

Bell, G. (1988) Sex and death in protozoa: the history of an obsession. Cambridge University Press, Cambridge.

Brown, J.H., Gillooly, J.F., Allen, A.P. (2004) Towards a metabolic theory of ecology. Ecology 85, 1771-1789.

Chahartaghi, M., Maraun, M., Scheu, S., Domes K. (2009) Resource depletion and colonization: A comparison between parthenogenetic and sexual Collembola species. Pedobiologia 52, 181189.

Christensen, B., Hvilsom, M., Pedersen, B.V. (1992) Genetic variation in coexisting sexual diploid and parthenogenetic triploid forms of Fridericia galba (Enchytraeidae, Oligochaeta) in a heterogeneous environment. Hereditas 117, 153-162.

Cianciolo, J.M., Norton, R.A. (2006) The ecological distribution of reproductive mode in oribatid mites as related to biological complexity. Experimental \& Applied Acarology 40, 1-25. 
Damuth, J. (1981) Population density and body size in mammals. Nature 290, 699-700.

Doroszuk, A., Wojewodzic, M.W., Kammenga, J.E. (2006) Rapid adaptive divergence of life-history traits in response to abiotic stress within a natural population of a parthenogenetic nematode. Proceedings of the Royal Society B: Biological Sciences 273, 2611-2618.

Downs, C.J., Hayes, J.P., Tracy, C.R. (2008) Scaling metabolic rate with body mass and inverse body temperature: a test of the Arrhenius fractal supply model. Functional Ecology 22, 239-244.

Ehnes, R.B., Rall, B.C., Brose, U. (2011) Phylogenetic grouping, curvature and metabolic scaling in terrestrial invertebrates. Ecology Letters 14, 993-1000.

Erdmann, G., Scheu, S., Maraun, M. (2012) Regional rather than local factors associated with forest type drive the community structure of soil living oribatid mites. Soil Biology \& Biochemistry, submitted.

Fischer, B.M., Schatz, H., Maraun, M. (2010a) Community structure, trophic position and reproductive mode of soil and bark-living oribatid mites in an alpine grassland ecosystem. Experimental \& Applied Acarology 52, 221-237.

Fischer, M., Bossdorf, O., Gockel, S., Hänsel, F., Hemp, A., Hesenmöller, D., Korte, G., Nieschulze, J., Pfeiffer, S., Prati, D., Renner, S., Schöning, I., Schumacher, U., Wells, K., Buscot, F., Kalko, E.K.V., Linsenmair, K.E., Schulze, E.D., Weisser, W.W. (2010b) Implementing large-scale and long-term functional biodiversity research: The Biodiversity Exploratories. Basic and Applied Ecology 11, 473-485.

Fisher, R.A. (1930). The genetical theory of natural selection. Clarendon Press, Oxford, UK.

Ghiselin, M.T. (1974) The Economy of Nature and the Evolution of Sex. University of California Press, Berkeley.

Grandjean, F. (1955) Caractère chitineux de l'ovipositeur, en structure normale, chez les oribates (Acariens). Archive de Zoologie Expérimentale et Générale 93, 96-106.

Grandjean, F. (1956) Observations sur les Oribates (34e série). Bulletin du Museum National d'Histoire Naturelle 28, 205-212.

Hadley, N.F. (1994) Water relations of terrestrial arthropods. Academic Press, London.

Hamilton, W.D. (1980) Sex versus non-sex versus parasite. Oikos 35, 282-290.

Haettenschwiler, S., Coq, S., Barantal, S., Handa, I.T. (2011) Leaf traits and decomposition in tropical rain forests: revisiting some commonly held views and towards a new hypothesis. New Phytologist 189, 950-965.

Heethoff, M., Koerner, L., Norton, R.A., Raspotnig, G. (2011) Tasty but protected: first evidence of chemical defense in oribatid mites. Journal of Chemical Ecology 37, 1037-1043.

Huhta, V., Koskenniemi, A. (1975) Numbers, biomass and community respiration of soil invertebrates in spruce forests at two latitudes in Finland. Annales Zoologici Fennici 12, 164182.

Illig, J., Langel, R., Norton, R.A., Scheu, S., Maraun, M. (2005) Where are the decomposers? Uncovering the soil food web of a tropical montane rain forest in southern Ecuador using stable isotopes (15N). Journal of Tropical Ecology 21, 589-593.

Jaenike, J. (1979) A hypothesis to account for the maintenance of sex within populations. Evolutionary Theory 3, 191-194.

Kondrashov, A.S. (1988) Deleterious mutations and the evolution of sexual reproduction. Nature $336,435-440$.

Luxton, M. (1975) Oribatid mites of a Danish beech wood soil. 2. biomass, calorimetry and respirometry. Pedobiologia 15, 161-200. 
Macfadyen, A. (1961) Improved funnel-type extractors for soil arthropods. Journal of Animal Ecology 30, 171-184.

Maraun, M., Scheu, S. (2000) The structure of oribatid mite communities (Acari, Oribatida): patterns, mechanisms and implications for future research. Ecography 23, 374-383.

Maraun, M., Salamon, J.A., Schneider, K., Schaefer, M., Scheu, S. (2003) Oribatid mite and collembolan diversity, density and community structure in a moder beech forest (Fagus sylvatica): effects of mechanical perturbations. Soil Biology \& Biochemistry 35, 1387-1394.

Maynard Smith, J. (1978) The evolution of sex. Cambridge University Press, Cambridge.

Muller, H. J. (1932) Some genetic aspects of sex. American Naturalist 8, 118-138.

Muller, H. J. (1964) The relation of recombination to mutational advance. Mutational Research 1, 29.

Norton, R.A. (1994) Evolutionary aspects of oribatid mite life histories and consequences for the origin of the Astigmata. In: Houck, M. (eds.), Mites. Ecological and evolutionary analyses of lifehistory patterns, pp. 99-135. Chapman and Hall, New York.

Norton, R.A., Palmer, S.C. (1991) The distribution, mechanisms and evolutionary significance of parthenogenesis in oribatid mites. In: Schuster, R., Murphy, P.W. (eds.), The Acari. Reproduction, development and life history strategies, pp. 107-136. Chapman and Hall, London.

Palmer, S.C., Norton, R.A. (1991) Taxonomic, geographic and seasonal distribution of thelytokous parthenogenesis in the Desmonomata (Acari: Oribatida). Experimental \& Applied Acarology 12, 67-81.

Peschel, K., Norton, R.A., Scheu, S., Maraun, M. (2006) Do oribatid mites live in enemy-free space? Evidence from feeding experiments with the predatory mite Pergamasus septentrionalis. Soil Biology \& Biochemistry 38, 2985-2989.

Pollierer, M.M., Langel, R., Koerner, C., Maraun, M., Scheu, S. (2007) The underestimated importance of belowground carbon input for forest soil animal food webs. Ecology Letters 10, 729-736.

Salamon, J.A., Alphei, J., Ruf, A., Schaefer, M., Scheu, S., Schneider, K., Suehrig, A., Maraun, M. (2006) Transitory dynamic effects in the soil invertebrate community in a temperate deciduous forest: Effects of resource quality. Soil Biology \& Biochemistry 38, 209-221.

Sanders, F.H., Norton, R.A. (2004) Anatomy and function of the ptychoid defensive mechanism in the mite Euphthiracarus cooki (Acari: Oribatida). Journal of Morphology 259, 119-154.

Sbordoni, M.C., Ketmaier, V., De Matthaeis, E., Taiti, S. (1997) Biochemical systematics and evolutionary relationships in the Trichoniscus pusillus complex (Crustacea, Isopoda, Oniscidea). Heredity 79, 463-472.

Schaefer, M., Schauermann, J. (1990) The soil fauna of beech forests - comparison between a mull and a moder soil. Pedobiologia 34, 299-314.

Scheu, S., Drossel, B. (2007) Sexual reproduction prevails in a world of structured resources in short supply. Proceedings of the Royal Society B: Biological Sciences 274, 1225-1231.

Schneider, K., Maraun, M. (2009) Top-down control of soil microarthropods - Evidence from a laboratory experiment. Soil Biology \& Biochemistry 41, 170-175.

Seyd, E.L., Seaward, M.R.D. (1984) The association of oribatid mites with lichens. Zoological Journal of the Linnean Society 80, 369-420.

Song, Y., Drossel, B., Scheu, S. (2011) Tangled bank dismissed too early. Oikos 120, 1601-1607.

Terhivuo, J., Saura, A. (2006) Dispersal and clonal diversity of north-European parthenogenetic earthworms. Biological Invasions 8, 1205-1218. 
Wallwork, J.A. (1983) Oribatids in forest ecosystems. Annual Review of Entomology 28, 109-130.

Weigmann, G. (2006) Die Hornmilben (Oribatida). In: Dahl, F. (ed.), Die Tierwelt Deutschlands 76, pp. 1-520. Goecke und Evers, Keltern.

West, S.A., Lively, C.N., Read, A.F. (1999) A pluralist view to sex and recombination. Journal of Evolutionary Biology 12, 1003-1012.

Williams, G.C. (1966) Natural selection costs of reproduction and a refinement of Lacks principle. American Naturalist 100, 687-690.

Williams, G.C. (1975) Sex and evolution. Monographs in Population Biology 8, 3-200.

\section{Literature used for the meta-analysis}

Alberti, G., Hauk, B., Köhler, H.R., Storch, V. (1996) Dekomposition. Qualitative und quantitative Aspekte und deren Beeinflussung durch geogene und anthropogene Belastungsfaktoren. Ecomed, Landsberg, Germany.

Bayer, S. (2008) Einfluss unterschiedlicher Baumartendiversitäten auf die Gemeinschaftsstruktur der saprophagen Bodenfauna: ein Streuaustauschexperiment im Laubmischwald. diploma thesis, University of Göttingen, Germany.

Berch, S.M., Battigelli, J.P., Hope, G.D. (2007) Response of soil mesofauna communities and oribatid mite species to site preparation treatments in high-elevation cutblocks in southern British Columbia. Pedobiologia 51, 23-32.

Eissfeller, V. (2007) Dichte, Diversität und Geschlechterverhältnis von Oribatiden in Bergregenwäldern unterschiedlicher Höhe (Süd-Ecuador). diploma thesis, Darmstadt University of Technology, Germany.

Erdmann, G. (2004) Stammauflauf von Arthropoden und im Besonderen von Oribatiden (Acari) auf Eichen in Urwaldfragmenten und Wirtschaftwäldern in Ost-Polen. diploma thesis, University of Würzburg, Germany.

Erdmann, G. (2012) PhD thesis, University of Göttingen, Germany.

Fabian, L. (1997) Oribatid mite communities (Acari, Oribatida) from the Anina mountains (The Carpathians, Romania). Abhandlungen und Berichte des Naturkundemuseums Görlitz 69, 41-51.

Froeberg, L., Solhoy, T., Baur, A., Baur, B. (2003) Lichen specificity of oribatid mites (Acari, Oribatida) on limestone walls in the Great Alvar of Öland, Sweden. Entomologisk Tidskrift 124, 177-182.

Fronczek, S. (2010) Reproductive mode of soil-living oribatid mites along an altitudinal gradient in a tropical montane rainforest in Southern Ecuador. bachelor thesis, University of Göttingen, Germany.

Garay, I. (1981) Étude d'un écosystème forestier mixte. IV. Données generals sur les microarthropods édaphiques et structure du peuplement d'Acariens Oribates. Revue d'Ecologie et de Biologie du Sol 18, 339-356.

Heiligenstadt, B. (1988) Zur Ökologie von Hornmilben (Acari: Oribatida) in einem ModerBuchenwald: Phänologie und räumliches Verteilungsmuster. master thesis, University of Göttingen, Germany.

Huhta, V., Hyvönen, R., Kaasalainen, P., Koskenniemi, A., Muona, J., Mäkelä, I., Sulander, M., Vilkamaa, P. (1986) Soil fauna of Finnish coniferous forests. Annales Zoologici Fennici 23, 345360. 
Huelsmann, A., Wolters, V. (1998) The effects of different tillage practices on soil mites, with particular reference to Oribatida. Applied Soil Ecology 9, 327-332.

Kehl, C. (1997) Die Hornmilbenzönosen (Acari, Oribatida) unterschiedlich stark degradierter Moorstandorte in Berlin und Brandenburg. PhD thesis, Free University of Berlin, Germany.

Lamoncha, K.L., Crossley, D.A. (1998) Oribatid mite diversity along an elevation gradient in a southeastern Appalachian forest. Pedobiologia 42, 43-55.

Lindo, Z., Winchester, N.N. (2007) Resident corticolous oribatid mites (Acari: Oribatida): Decay in community similarity with vertical distance from the ground. Ecoscience 14, 223-229.

Luxton, M. (1981) Studies on the oribatid mites of a Danish beech wood soil. III. Introduction to field populations. Pedobiologia 21, 301-311.

McLean, M.A., Parkinson, D. (1998) Impacts of the epigeic earthworm Dendrobaena octaedra on oribatid mite community diversity and microarthropod abundances in a pine forest floor: a mesocosm study. Applied Soil Ecology 7, 125-136.

Migge, S. (1996) Hornmilben (Oribatida) in einem Gradienten von Fichte (Picea abies) zu Buche (Fagus sylvatica) auf Buntsandstein: Relation zu Streualter und mikrobieller Biomasse. diploma thesis, University of Göttingen, Germany.

Migge, S., Maraun, M., Scheu, S., Schaefer, M. (1998) The oribatid mite community (Acarina) on pure and mixed stands of beech (Fagus sylvatica) and spruce (Picea abies) at different age. Applied Soil Ecology 9, 119-126.

Schneider, K. (2001) Der Einfluss von Habitatfragmentierung, Sonneneinstrahlungsintensität und winterlicher Staunässe auf die Mikroarthropoden-Gemeinschaft eines StieleichenHainbuchenwaldes. diploma thesis, Darmstadt, University of Technology, Germany.

Schulz, E. (1991) Die Milbenfauna (Acari: Mesostigmata und Cryptostigmata) in Lebensräumen auf Kalkgestein: Populationsbiologie, Sukzession und Beziehung zum Lebensraum. Berichte des Forschungszentrums Waldökosysteme A 79.

Toschki, A. (2008) Eignung unterschiedlicher Monitoring-Methoden als Grundlage zum Risk Assessment für Agrarsysteme. PhD thesis, University of Aachen, Germany.

Totschnig, U., Schatz, H. (1997) Hornmilben in einem Auwald an der Isel bei Glanz (Osttirol): Zönologie. Berichte des naturwissenschaftlich-medizinischen Vereins in Innsbruck 85, 95-109.

Weigmann, G., Jung, E. (1992) Die Hornmilben (Acari, Oribatida) an Straßenbäumen in Stadtzonen unterschiedlicher Luftbelastung in Berlin. Zoologische Beiträge N F 34, 273-287.

Woltemade, H. (1982) Zur Ökologie baumrindenbewohnender Hornmilben (Acari, Oribatei). Berichte der Gesellschaft Naturforschender Freunde zu Berlin N F 22, 118-139.

Wunderle, I. (1992) Die Oribatiden-Gemeinschaften (Acari) der verschiedenen Habitate eines Buchenwaldes. Carolinea 50, 79-144. 


\section{Appendix}

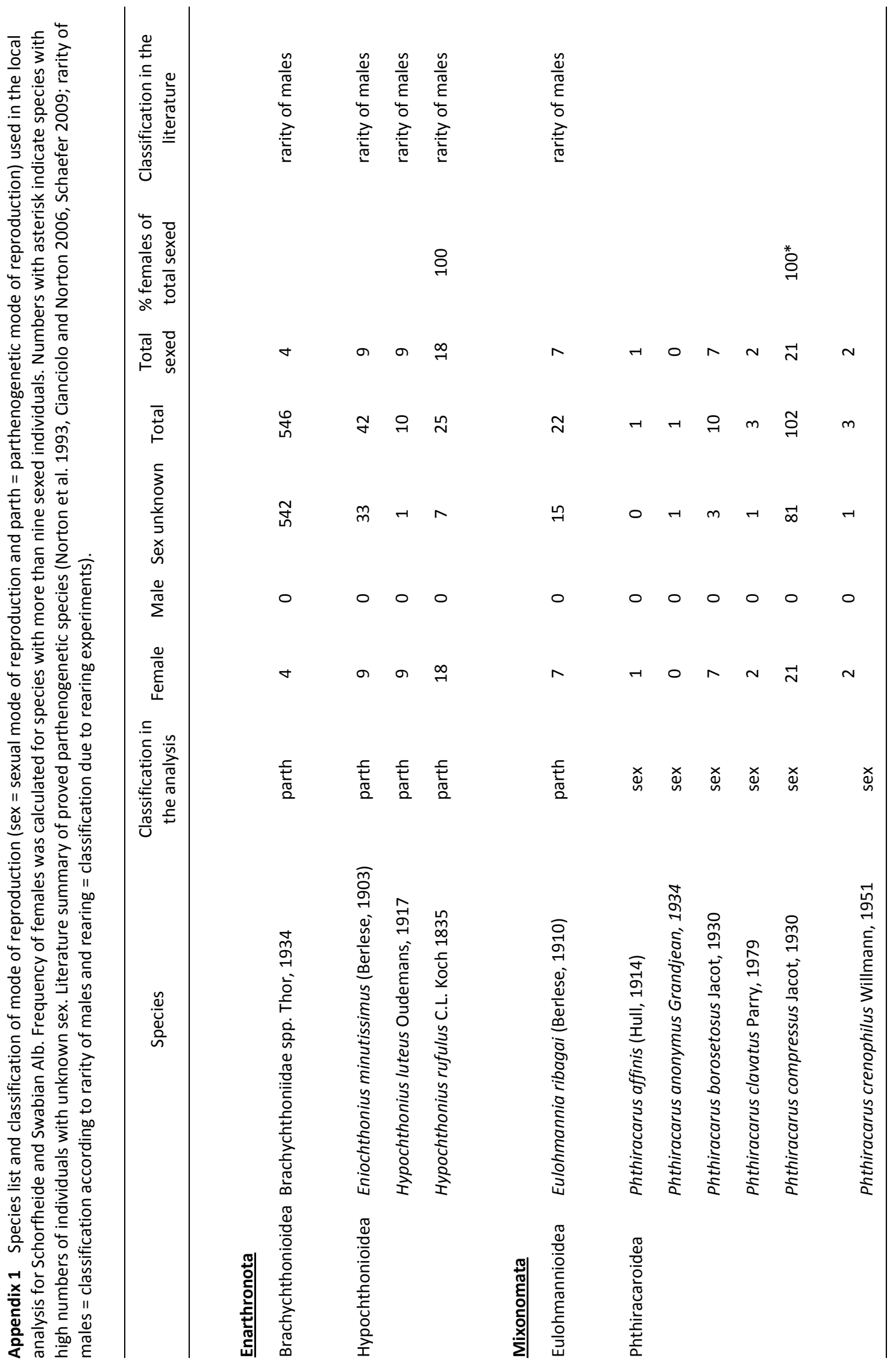




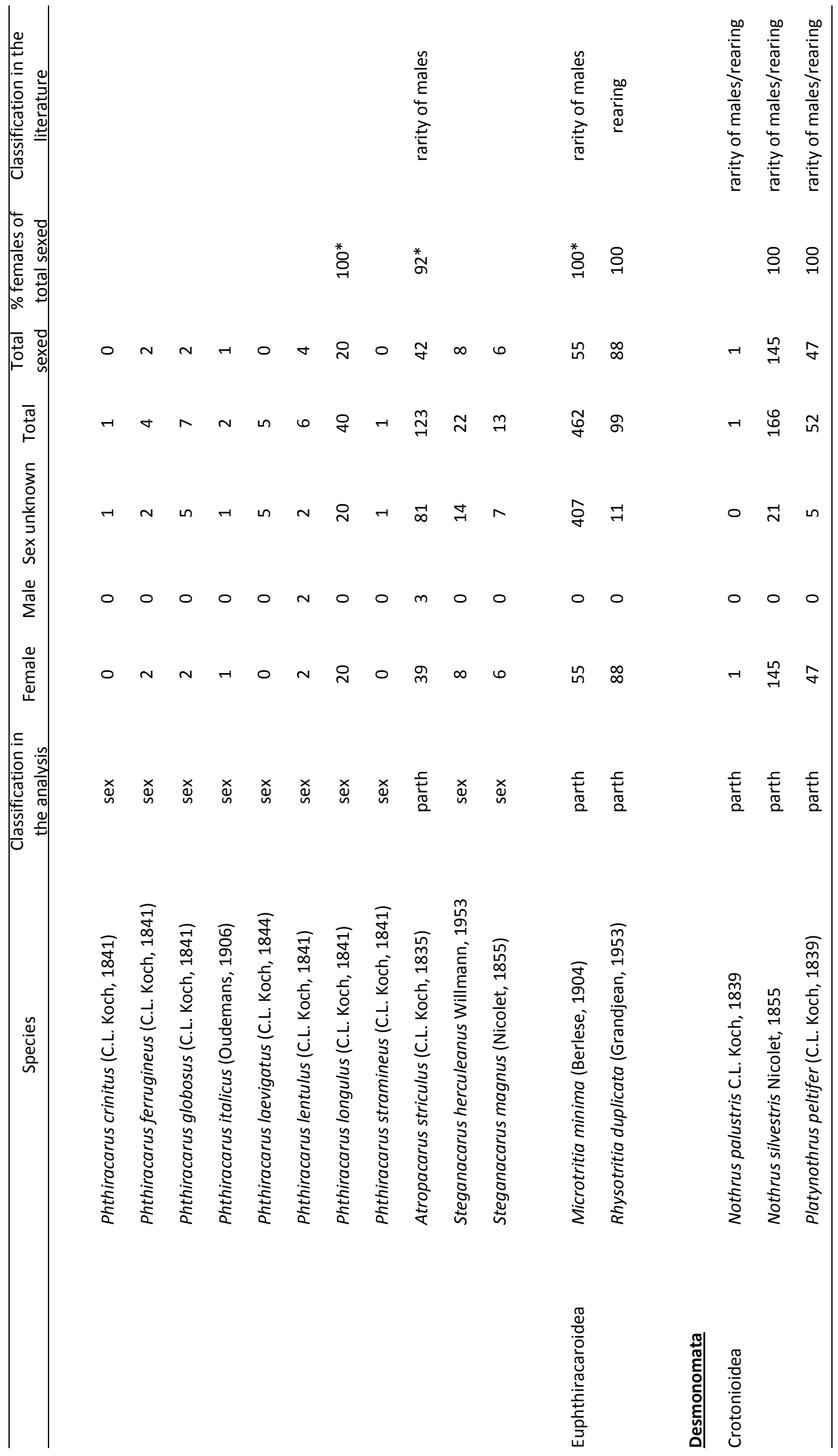




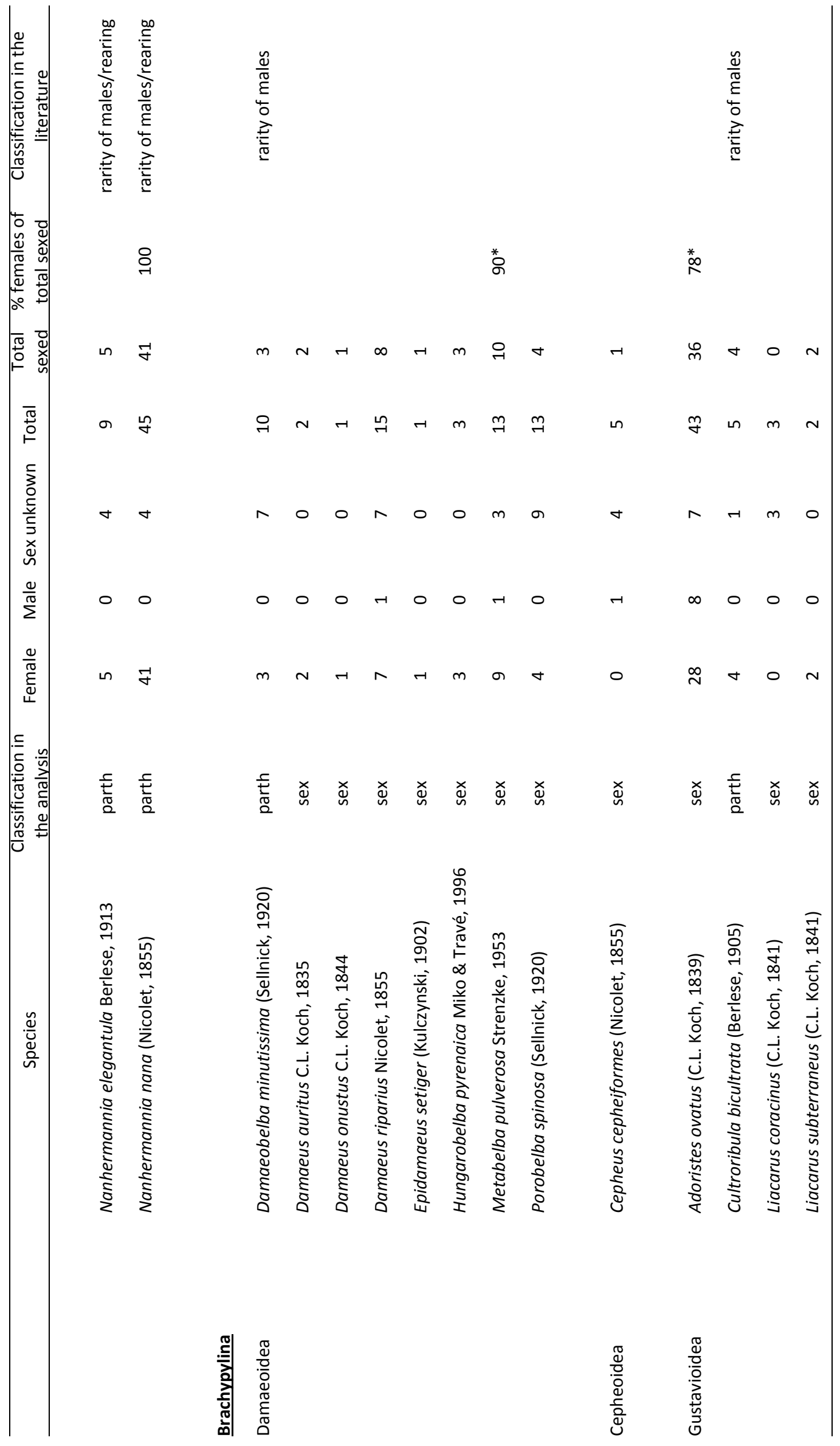




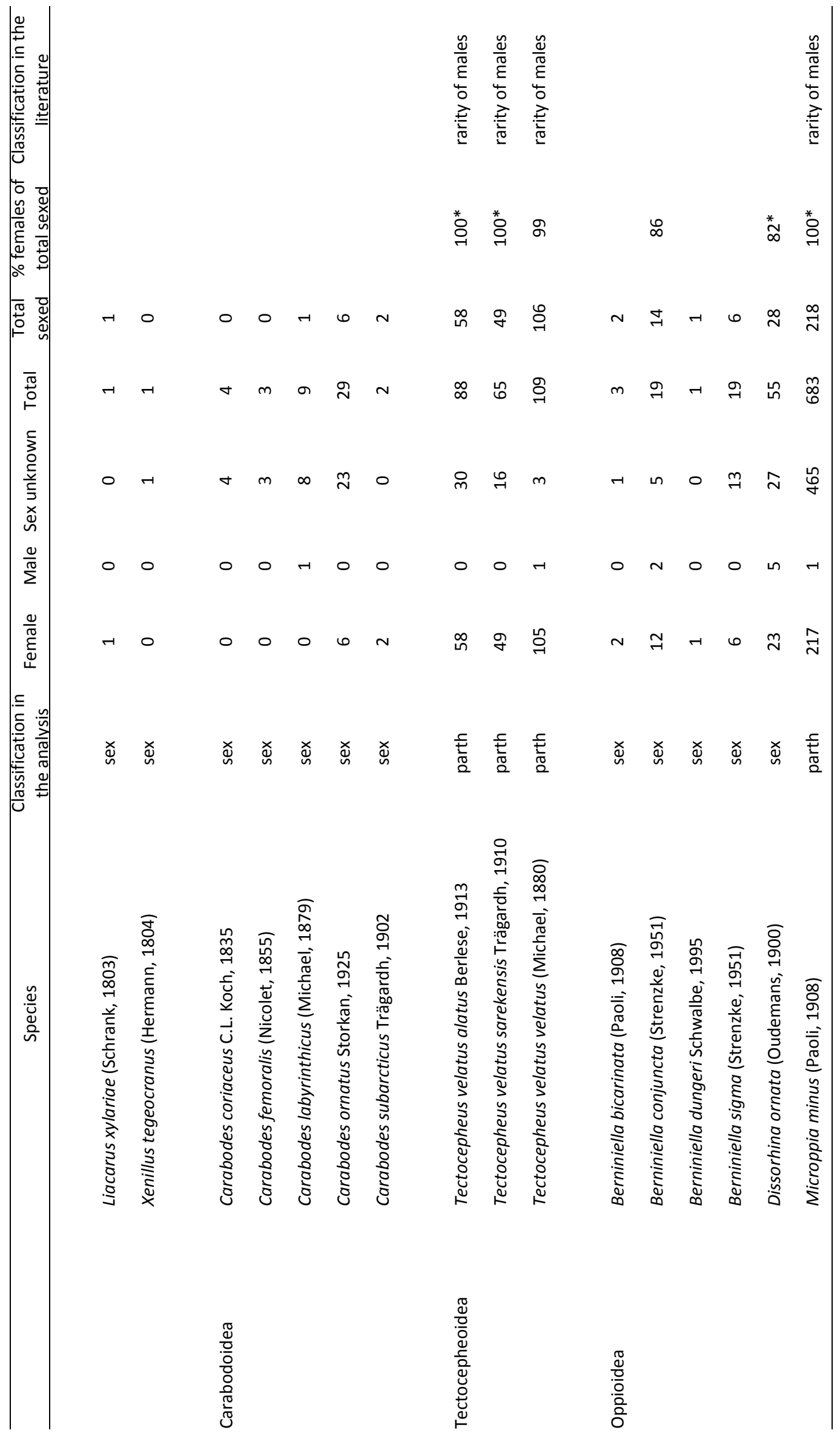




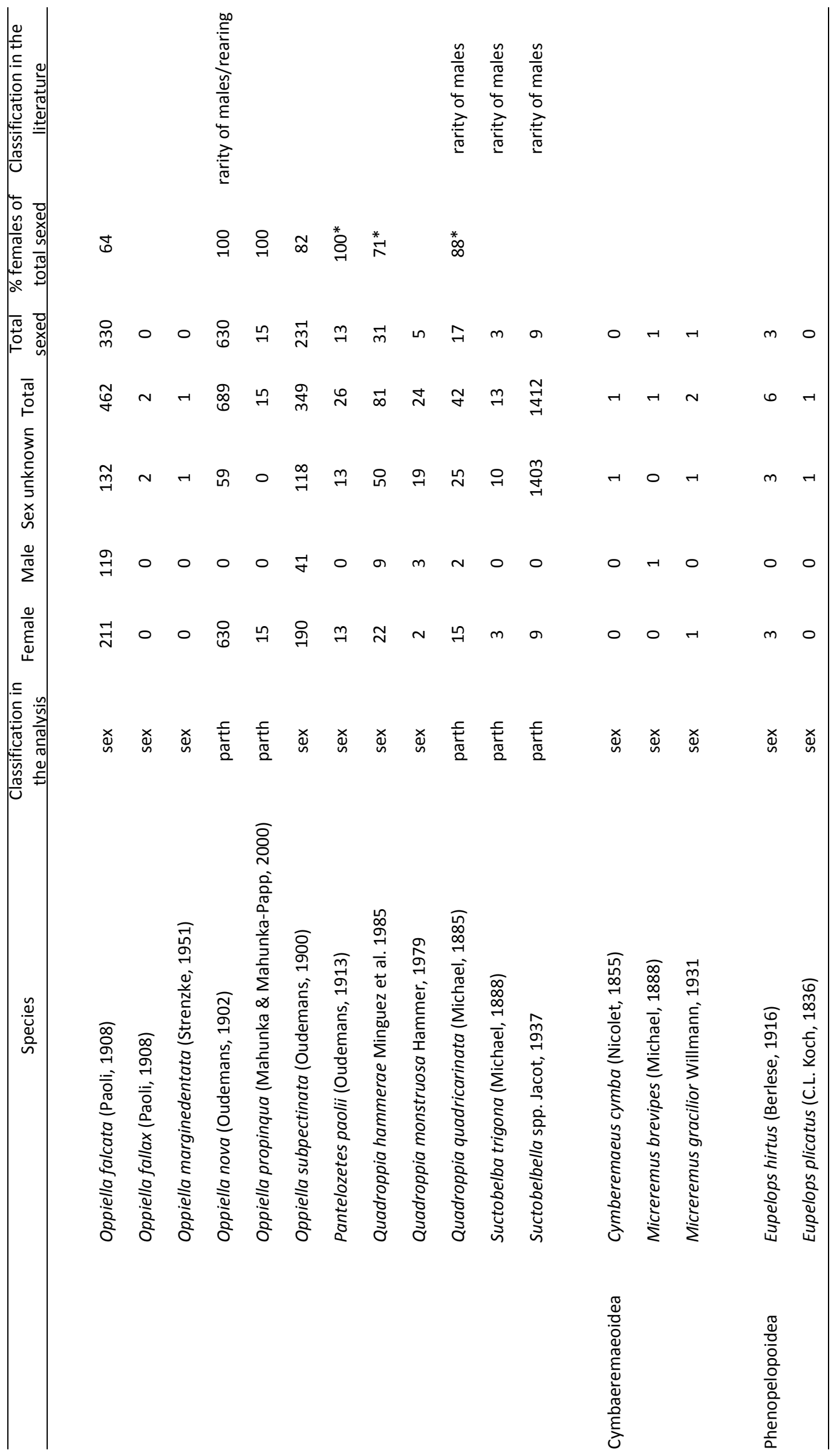




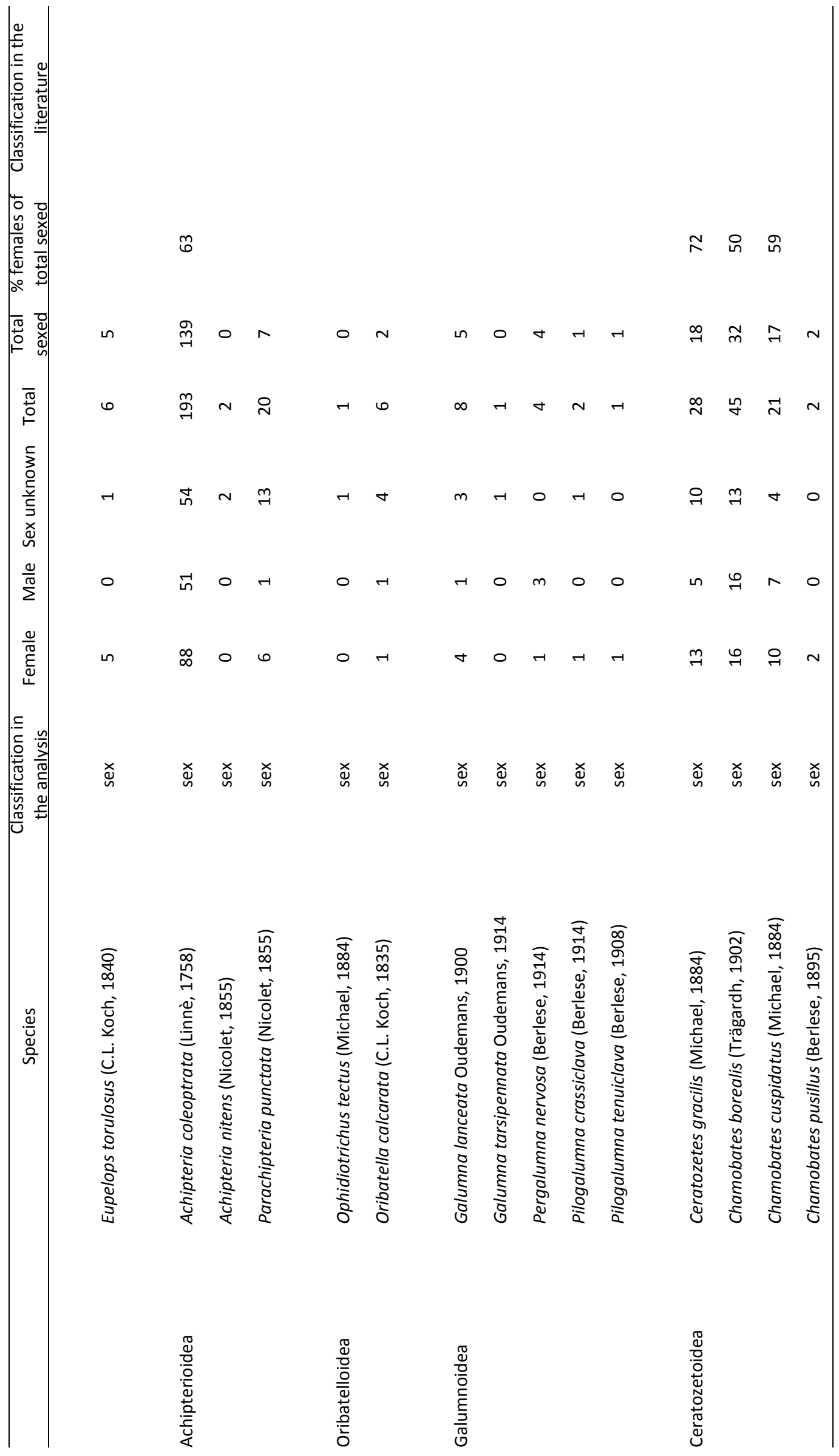




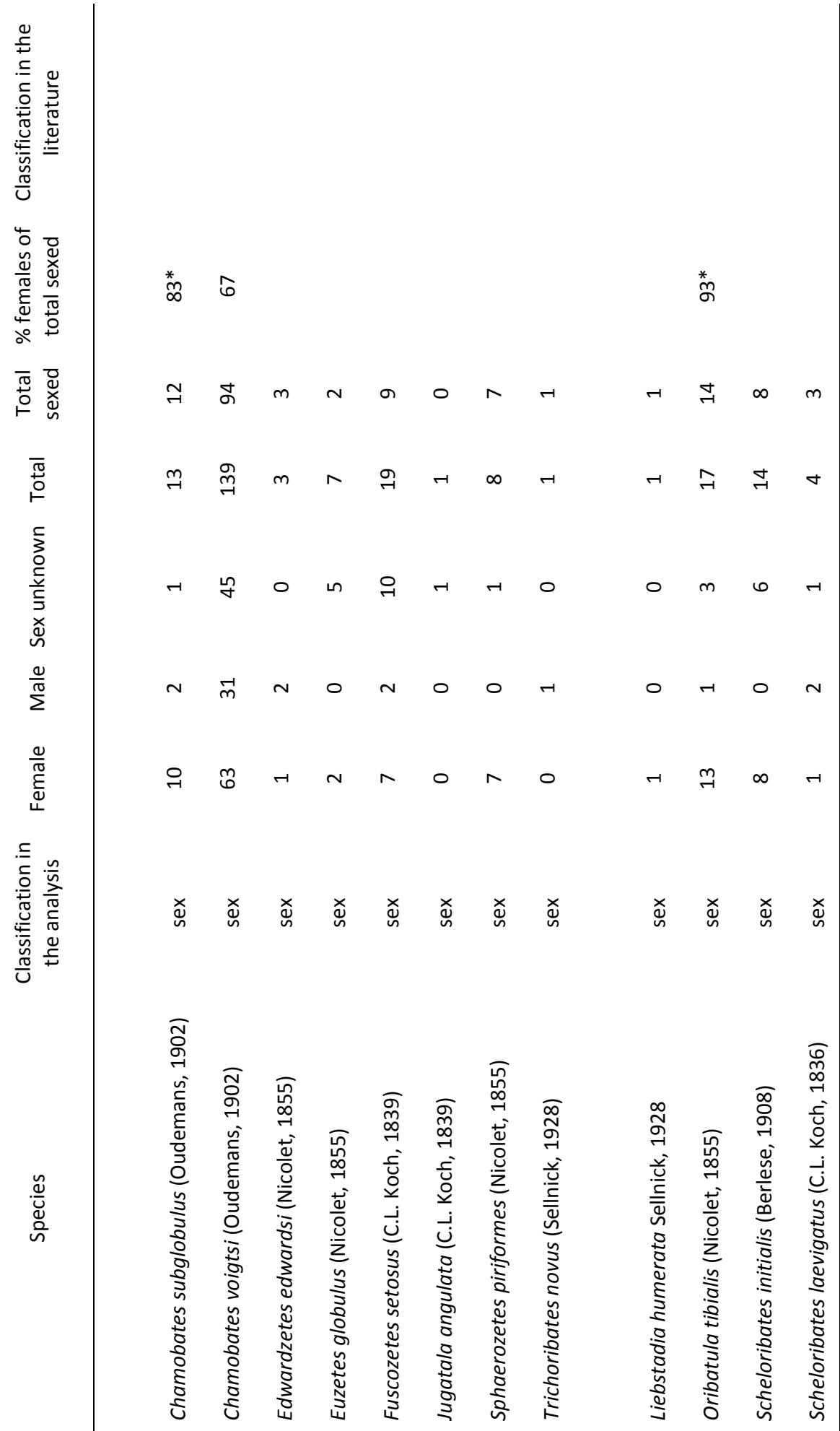




\section{Chapter 5}

\section{Oribatid mite (Acari, Oribatida) density on}

tree trunks is regulated by food-resources

Erdmann, G., Scheu, S., Maraun M. 


\section{Abstract}

The bark of trees forms a habitat exposed to harsh abiotic conditions, contrasting the soil as habitat with buffered climatic conditions. Oribatid mites are typical soil living arthropods, however, a large number of species also occur on the bark of trees. Ten percent of the 10,000 described species reproduce parthenogenetically. In contrast to the high frequency of parthenogenetic species in habitats with strongly fluctuating climatic conditions, the bark of trees in the temperate zone is dominated by sexual reproducing oribatid mites, whereas in soil species reproducing parthenogenetically predominante. The 'Structured Resource Theory of Sexual Reproduction' (SRTS) aims at explaining this contradiction. According to this theory sexual reproduction dominates in habitats where resources are limited or difficult to access. We investigated if resource availability limits the density of oribatid mites and the fraction of parthenogenetic individuals on the bark of trees as predicted by the SRTS. Resource availability was manipulated by monthly fertilization of bark with nitrogen, carbon, both nitrogen and carbon, and water as control. The uptake of resources by oribatid mites was evaluated after three months of fertilization using stable isotopes $\left({ }^{15} \mathrm{~N},{ }^{13} \mathrm{C}\right)$. Oribatid mites incorporated $\mathrm{C}$ but little $\mathrm{N}$ of the added resources. $\mathrm{C}$ addition increased densities of oribatid mites, indicating that the bark of trees indeed is a resource-limited habitat for oribatid mites. The occurrence of parthenogenetic individuals was generally scarce. The results confirm predictions of the SRTS and suggest that the lack of oribatid mite species reproducing parthenogenetically on the bark of trees in temperate regions is due to the limited availability of resources with the sexual species present being well adapted to fluctuating and harsh environmental conditions.

\section{Introduction}

The evolution and maintenance of sexually reproducing species bearing the two-fold costs of producing males in comparison to asexuals has been termed 'the queen of problems' in evolutionary biology (Maynard Smith 1971, Williams 1975). Weismann (1889) proposed the production of genetically variable offspring as main advantage of sex and recombination. Several theories exist trying to identify the factors responsible for the dominance of sexual reproduction in most animal taxa. The theories fundamentally differ in the considered factors ranging from temporal and spatial variations in abiotic factors to resource availability to 
parasite load (West et al. 1999, Scheu and Drossel 2007). Recently, an integrative approach focusing on resources as major driving force of sexual reproduction has been proposed, i.e., the 'Structured Resource Theory of Sexual Reproduction' (SRTS) (Scheu and Drossel 2007, Song et al. 2012).

The fundamental assumption of the SRTS is the availability of limited amounts of resources for a population with a limited number of genotypes consuming only part of these resources which are not or only partly available to the next generation. Sexual offspring can exploit underutilized resources and thereby outcompete asexually produced offspring relying on identical resources as their parents. The model differentiates explicitly between biotic and abiotic density-dependent factors, and physicochemical density-independent factors. The model predicts asexual reproduction to predominate (1) in habitats with an excess of resources (no adaptation to limited resources needed), (2) in habitats with a small number of resources (exploited successfully by well adapted clonal linages), (3) in populations with a high number of genotypes of asexuals (successfully competing with sexually produced progeny), and (4) in habitats with high mortality due to density-independent factors, i.e., in habitats characterized by harsh and/or strongly fluctuating environmental conditions (Scheu and Drossel 2007, Song et al. 2012).

Soils in temperate forests are climatically buffered and experience low amplitudes in temperature and moisture. In contrast, the bark of tree trunks forms a habitat with strongly fluctuating temperature and moisture conditions (Nicolai 1986, 1989) and, therefore, bark living species are considered to be exposed to harsh abiotic conditions (Wunderle 1992, Proctor et al. 2002). Based on these assumptions death rates should be high and densityindependent; according to SRTS resulting in high frequency of parthenogenetic species.

Oribatid mites are good model organisms to investigate mechanisms responsible for the dominance of sexual vs. asexual reproduction (Norton and Palmer 1991). They are typical soil living microarthropods which also colonize the bark of trees. Oribatid mites reproduce sexually or parthenogenetically via thelytoky (presumably by terminal fusion automixis; Heethoff et al. 2009). Ten percent of the 10,000 described oribatid mite species worldwide (Subias 2004, Schatz 2005) are parthenogenetic (Norton and Palmer 1991, Norton et al. 1993). Geographic or cyclical parthenogenesis is not known (Palmer and Norton 1991, Norton et al. 1993). Oribatid mites have slow reproduction cycles with generation times of 50 weeks or more for common species in temperate zones (Heethoff et al. 2009). Within oribatid mites large asexual clusters exist indicating that asexual lineages are ancient (Maraun et al. 2004). 
Oribatid mites are dominant microarthropods in forest soils. Densities of $>100,000$ individuals per square meter are typical for base poor forests of the temperate zone. Typically, parthenogenetic oribatid mites dominate in forest soils of the temperate zone (Maraun et al. 2003, Fischer et al. 2010a). In contrast, few parthenogenetic oribatid mites occur on the bark of trees (Erdmann et al. 2006, Fischer et al. 2010a) apparently contradicting predictions of the SRTS. The frequency of parthenogenetic oribatid mites changes fundamentally within few centimeters along the transect from soil to the bark of trees (Wunderle 1992, Proctor et al. 2002, Fischer et al. 2010a). This suggests that on the bark of trees factors favouring sexual reproduction predominate which is consistent with the finding that the bark-living Crotoniidae reevolved sexual reproduction from parthenogenetic ancestral Camisiidae living in soil (Domes et al. 2007a).

We experimentally manipulated the resource availability on the bark of trees to investigate whether the sexually reproducing bark living oribatid mites are limited by resources as assumed by the SRTS. We added nitrogen (ammonium nitrate, naturally rich in ${ }^{15} \mathrm{~N}$ ) and carbon (cane sugar; naturally rich in ${ }^{13} \mathrm{C}$ ) to the bark surface to differentiate between the limitation by algae (fostered by addition of $\mathrm{N}$ ) and saprotrophic fungi (fostered by addition of glucose). Uptake of the added elements by oribatid mites was followed by analyzing stable isotope ratios in oribatid mites.

Oribatid mites were sampled after three and eight months to investigate (1) the incorporation of $\mathrm{N}$ an $\mathrm{C}$ in the added resources into oribatid mites, (2) changes in oribatid mite density due to increased resource availability, (3) and changes in the proportion of parthenogenetic oribatid mites with increasing amount of resources indicating a resourcelimitation.

\section{Materials and Methods}

\subsection{Study sites}

The study was conducted at six forest sites located in the surrounding of the National Park Hainich in Central Germany (285-550 m a.s.I.). The sites form part of the 'Biodiversity Exploratories', a long term monitoring project and experimental platform (Fischer et al. 2010b; www.biodiversity-exploraties.de). The study area is characterized by a mean annual precipitation of $500-800 \mathrm{~mm}$ and a mean annual temperature of $6.5-8.0^{\circ} \mathrm{C}$. Soil type is Luvisol on Triassic Limestone. The six forest sites were at least one $\mathrm{km}$ and at most $20 \mathrm{~km}$ away from 
each other. Three forests were age class forests with approx. 70 y old beech trees (Fagus sylvatica) and three were selective cutting forests with 70-100 y old mature beech trees.

\subsection{Sampling design}

The experimental design was full-factorial with the two factors carbon and nitrogen as fertilizers, and the six forest sites as blocks. A solution containing $0.4 \mathrm{~g}$ ammonium nitrate $(\mathrm{N})$ and $4.2 \mathrm{~g}$ cane sugar (C), and a combination of both (CN) was sprayed on the bark of beech trees using a plant moistener. Trees sprayed with deionized water served as control (Ctrl). Spraying was done in breast height on an area of $30 * 60 \mathrm{~cm}\left(1800 \mathrm{~cm}^{2}\right)$ at the weather side of the trees were algal cover is high. Trees were sprayed at monthly intervals to continuously increase resource availability. The amount of nitrogen and carbon added resembled the input of nitrogen and carbon via leaf litter to the forest soil $\left(7.27 \pm 0.38 \mathrm{gN} \mathrm{m}^{-2} \mathrm{y}^{-1}, 278.32 \pm 14.81 \mathrm{gC}\right.$ $\mathrm{m}^{-2} \mathrm{y}^{-1}$; Cotrufo et al. 2001). Samples were taken after three and eight months. The experiment started on April 7th, 2009. As treatment effects did not vary among sampling dates, data of the two samplings were pooled.

For sampling the bark first was brushed using a smooth toothbrush then the topmost layer of the bark was cut off with a knife to collect the oribatid mites in crevices. The bark samples were extracted by heat (Macfadyen 1961), collected in ethylene glycol and stored in $70 \%$ ethanol. Adult oribatid mites were determined to species level using Weigmann (2006), juveniles were counted.

Oribatid mites from the first sampling date, bark samples from the first sampling date, ammonium nitrate and cane sugar were weighed into tin capsules for stable isotope analysis. Stable isotope measurements for bark were replicated twice, those for ammonium nitrate and cane sugar four times. Stable isotopes of the most abundant bark inhabiting oribatid mite species Chamobates subglobulus, Chamobates pusillus, Chamobates borealis, Eupelops hirtus and Oribatella calcarata, were measured. Stable isotopes were measured by a coupled system of an elemental analyser (NA 1500, Carlo Erba, Milan) and a mass spectrometer (MAT 251, Finnigan). Stable isotope ratio was expressed as $\delta$ notation with $\delta^{15} \mathrm{~N}(\%)$ or $\delta^{13} \mathrm{C}(\%)=$ $\left(R_{\text {sample }}-R_{\text {standard }}\right) / R_{\text {standard }} * 1000 . R_{\text {sample }}$ and $R_{\text {standard }}$ representing the respective isotope ratios of the sample or of the standard. For ${ }^{15} \mathrm{~N}$ atmospheric nitrogen and for ${ }^{13} \mathrm{C}$ PD belemnite (PDB) served as the primary standard. Acetanilide $\left(\mathrm{C}_{8} \mathrm{H}_{9} \mathrm{NO}\right.$, Merck, Darmstadt) was used for internal calibration. 


\subsection{Statistical analysis}

Variances of oribatid mite densities and arcsine-transformed proportions of parthenogenetic individuals were homogeneous (Levene's test, $p>0.07$ for oribatid mite density; $p>0.5$ for proportion of parthenogenetic individuals). Two-factorial ANOVAs with the main factors $\mathrm{N}$ and C, and with forest sites as blocks were carried out. Tukey's Honestly Significant Difference test (HSD) was performed for comparison of means. Statistical analyses were implemented using SAS v.9.2 (SAS Institute Inc., Cary, NC, USA). Means and standard errors in text and graphs are shown for untransformed data.

Species encountered less than twice in the pooled dataset were excluded from the analysis. Data were $\log (x+1)$ transformed to improve homogeneity of variances. Differences in oribatid mite species composition among the forest sites and fertilization treatments (with fertilization treatments as supplementary variable) were analyzed with PCA using CANOCO 4.5 (Jongman et al. 1995, Braak and Smilauer 2002).

For each individual tree differences in stable isotope signatures between the bark and the respective oribatid mites were calculated. Changes in stable isotope signatures of the oribatid mite species studied due to experimental treatments were inspected using Discriminant Function Analysis (DFA). Squared Mahalanobis Distances between group centroids and the reliability of the sample classifications were determined. DFA was calculated with STATISTICA 9.1 software package (Statsoft Tulsa, USA).

\section{Results}

\subsection{Density}

Pooled oribatid mite densities in the control and $\mathrm{N}$ treatment were similar with $80.6 \pm 22.7$ and $77.0 \pm 34.8$ ind. per $1800 \mathrm{~cm}^{2}$, respectively (Fig. 1). In contrast, oribatid mite densities were significantly increased due to the addition of $C$ and $C N$ reaching $180.2 \pm 75.5$ and $144.2 \pm 63.4$ ind. per $1800 \mathrm{~cm}^{2}$, respectively ( $F 1,15=4.90 ; p=0.043$ for the effect of $C$ ). Further, oribatid mite density varied significantly among forest sites $\left(F_{5,15}=6.69, p=0.002\right.$ for the effect of block). Neither the addition of $N\left(F_{1,15}=0.28 ; p=0.61\right)$ nor the interaction of $N$ and $C\left(F_{1,15}=\right.$ $0.18 ; p=0.674)$ were significant. 
The fraction of individuals of parthenogenetic species was low and averaged $3.8 \pm 1.2 \%$ and did not vary significantly with experimental treatments $\left(F_{8,15}=1.22 ; p=0.351\right.$ for the overall model).

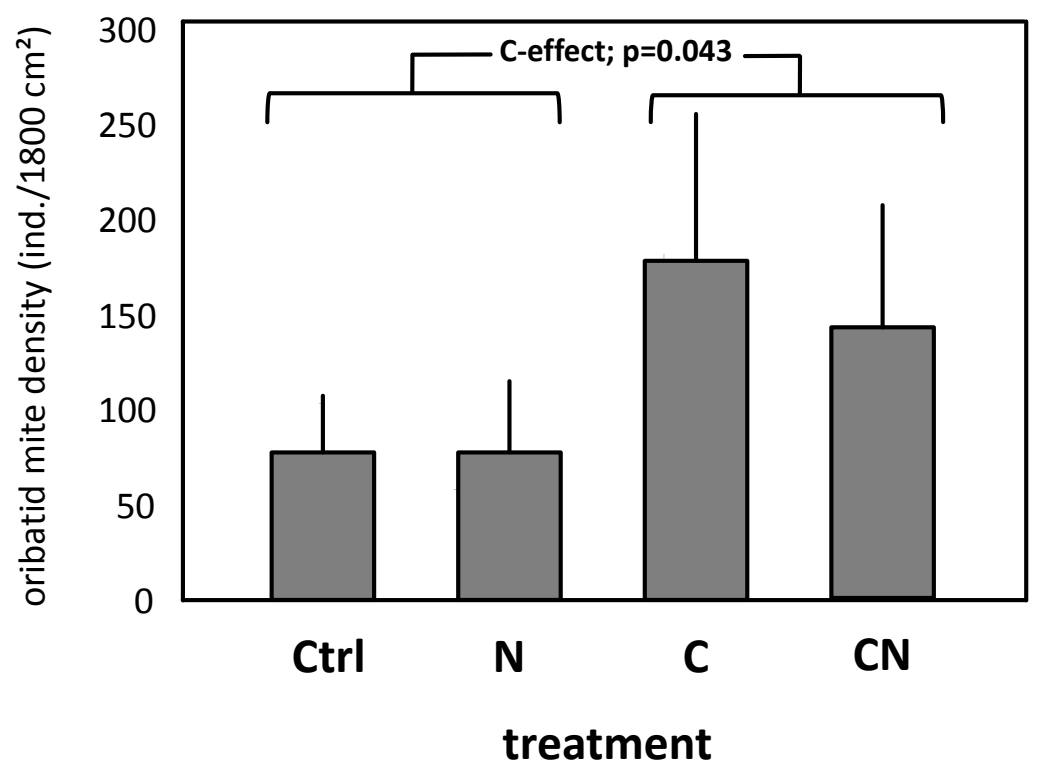

Fig. 1 Changes in the density of oribatid mites on the bark of trees after addition of $\mathrm{N}$ (ammonium nitrate), $\mathrm{C}$ (cane sugar) and CN (ammonium nitrate and cane sugar), and water as control (Ctrl). Pooled data after 4 and 8 months; means \pm standard error; for statistical analysis see text.

\subsection{Community structure}

Oribatid mite communities differed significantly between forest sites (data not shown) but also between experimental treatments (Fig. 2). Community structure was similar in the control and $\mathrm{N}$ treatment, whereas in $\mathrm{C}$ and $\mathrm{CN}$ treatments the community shifted towards higher abundances of the species Chamobates borealis and Zygoribatula exilis and of juvenile oribatid mites. 


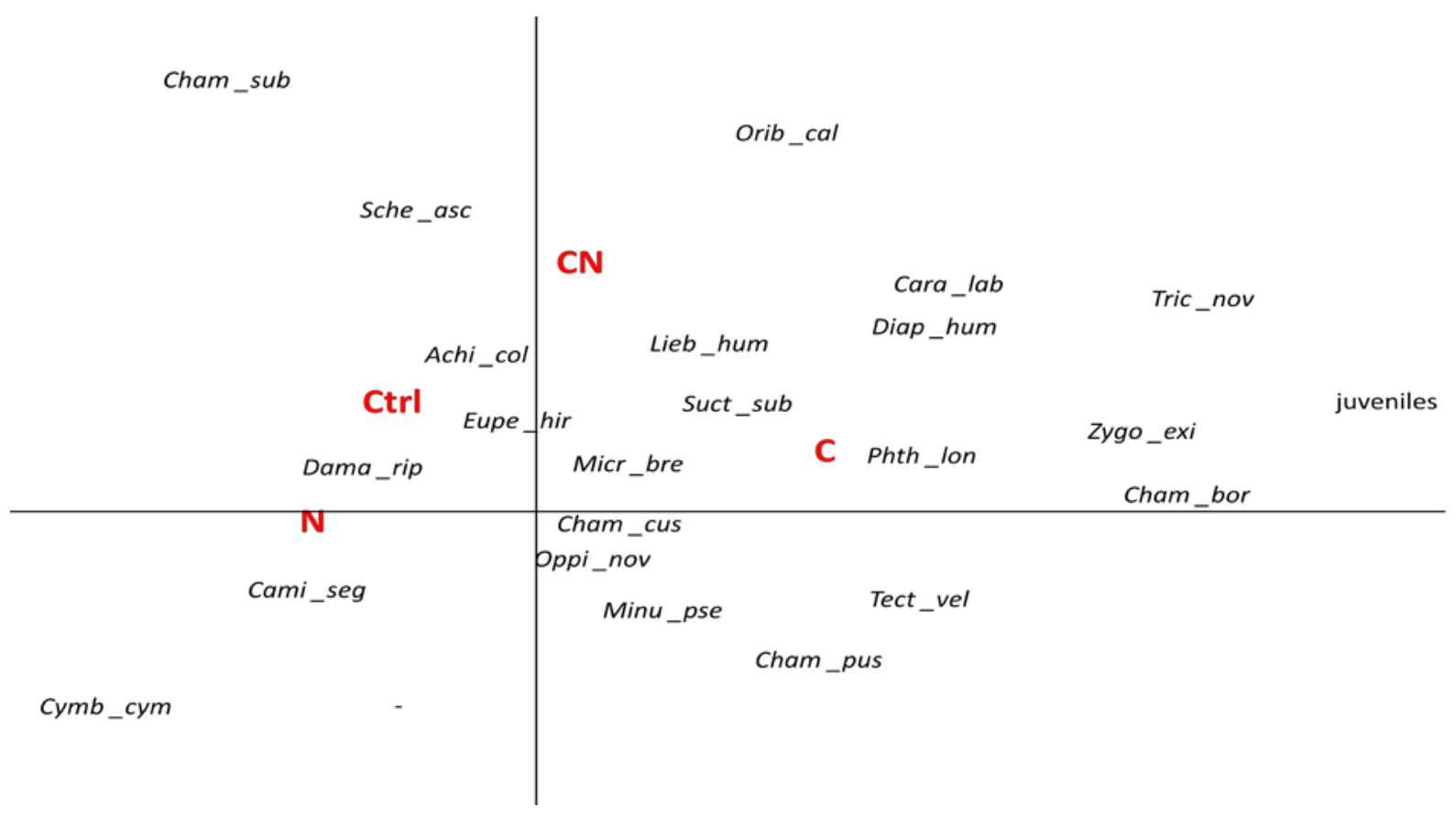

Fig. 2 Principal Components Analysis (PCA) of the community structure of oribatid mites (species names in italics; for full species names see Appendix) on the bark of trees after addition of $\mathrm{N}$ (ammonium nitrate), $\mathrm{C}$ (cane sugar) and CN (ammonium nitrate and cane sugar), and water as control (Ctrl). Eigenvalues of the 1st axis 0.327 and of the 2 nd axis 0.150 .

\subsection{Stable isotopes}

The $\delta^{15} \mathrm{~N}$ value of ammonium nitrate was $2.71 \pm 0.01 \%$, the $\delta^{13} \mathrm{C}$ value of cane sugar was $11.18 \pm 0.01 \%$. Values of $\delta^{15} \mathrm{~N}$ and $\delta^{13} \mathrm{C}$ of the bark of trees averaged $5.45 \pm 0.20 \%$ ond -27.26 $\pm 0.11 \%$. On average, oribatid mites were enriched in ${ }^{15} \mathrm{~N}$ relative to the bark by $1.65 \pm 0.23 \%$, $1.64 \pm 0.16 \%$ o, $0.80 \pm 0.22 \%$ and $0.96 \pm 0.31 \%$ in control, $\mathrm{N}, \mathrm{C}$ and $\mathrm{CN}$ treatments, respectively. Respective values for ${ }^{13} \mathrm{C}$ were $1.42 \pm 0.09 \%$, $1.25 \pm 0.18 \%$ o, $2.34 \pm 0.30 \%$ and $2.22 \pm 0.16$.

Stable isotope values differed significantly between the four treatments (Wilk's Lambda = $0.70, F_{6,148}=4.89, p<0.0001 ;$ Fig. 3 ) with the first root being significant. The enrichment in ${ }^{13} \mathrm{C}$ of oribatid mites relative to the bark was responsible for the significant differences between the treatments (Wilk's Lambda $=0.90, F_{3,74}=7.18, p<0.0003$ ). Oribatid mites of the $C$ and $C N$ treatments were significantly more enriched in ${ }^{13} \mathrm{C}$ than oribatid mites of the control and $\mathrm{N}$ treatments $(p<0.001)$. In contrast to ${ }^{13} \mathrm{C},{ }^{15} \mathrm{~N}$ values of oribatid mites relative to the bark did not differ between the treatments (Wilk's Lambda $=0.748 ; F_{3,74}=1.828 ; p=0.149$ ). 


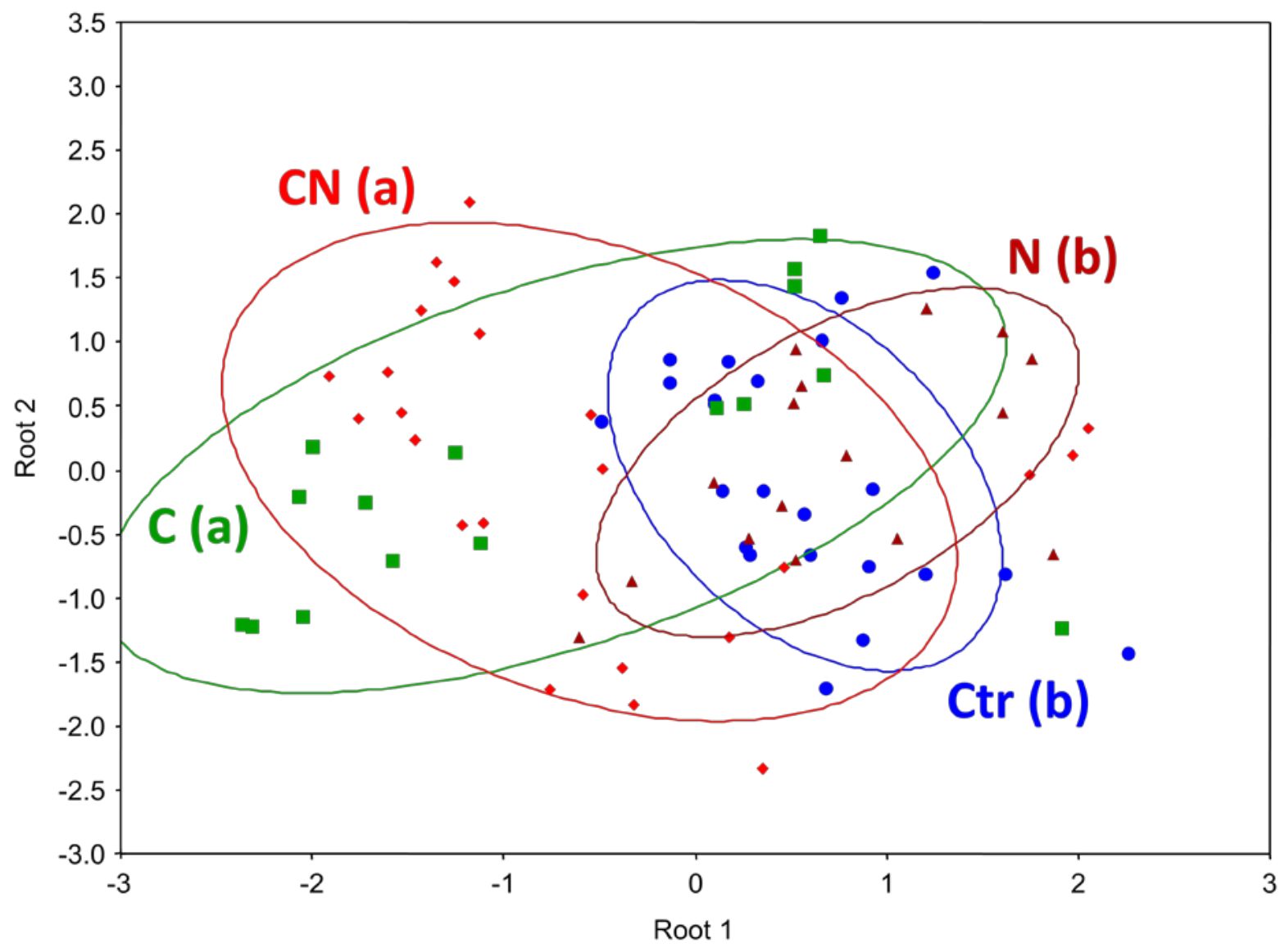

Fig. 1 Discriminant Function Analysis (DFA) of $\delta^{15} \mathrm{~N}$ and $\delta^{13} \mathrm{C}$ values in the bark of trees and in oribatid mites after addition of $\mathrm{N}$ (ammonium nitrate), $\mathrm{C}$ (cane sugar) and CN (ammonium nitrate and cane sugar), and water as control (Ctrl). Ellipses represent confidence ranges at $\mathrm{P}=0.2$. Treatments labeled with different letters (in parenthesis) differ significantly at $\mathrm{P}<0.05$ ).

\section{Discussion}

Results of our study showed that bark living oribatid mite communities on tree trunks are dominated by sexual species, and that oribatid mite densities are limited by the availability of food resources. These findings appear counterintuitive as tree trunks are exposed to strong variations in environmental conditions suggesting that populations are structured by densityindependent factors favoring species with parthenogenetic reproduction as indicated by SRTS (Scheu and Drossel 2007, Song et al. 2012). In contrast to these assumptions, results of the present study indicate that bark living oribatid mites are in fact regulated by the availability of food resources i.e., by density-dependent factors favoring sexually reproducing species. Sexual organisms produce genetically variable offspring allowing the use of underutilized resources left over from the parental generation. 
Addition of cane sugar caused an increase in ${ }^{13} \mathrm{C} /{ }^{12} \mathrm{C}$ ratios of oribatid mites towards the ratios of cane sugar. Obviously, oribatid mites incorporated cane sugar $\mathrm{C}$ presumably via consumption of saprotrophic fungi. However, enrichment in ${ }^{13} \mathrm{C}$ varied markedly among oribatid mite individuals suggesting that some individuals did not incorporate cane sugar C, while others fed on resources containing cane sugar $C$.

The ${ }^{15} \mathrm{~N} /{ }^{14} \mathrm{~N}$ ratio of oribatid mites did not differ between treatments with and without $\mathrm{N}$ addition (ammonium nitrate). We expected $\mathrm{N}$ to be incorporated by algae and lichens (Ullrich et al. 1998) which are assumed to be an important food source of bark living oribatid mites (Erdmann et al. 2007, Maraun et al. 2011). Potentially, the label was not strong enough to be detected in the next trophic level or may have resulted in the production of defense compounds rather than biomass as observed in plants (Koricheva 2002). Further experiments are needed to trace the pathway of nitrogen from mineral sources to algae and lichens to microarthropod consumers on the bark of trees.

Oribatid mite densities increased significantly in treatments with $\mathrm{C}$ but not in those with $\mathrm{N}$. This supports the findings of the stable isotope analysis that the addition of $\mathrm{N}$ did not improve oribatid mite nutrition. The increase in oribatid mite density by the addition of $\mathrm{C}$ was due to an increase of typical bark living oribatid mite species and juveniles suggesting that the increased resource supply increased reproduction of these species. Addition of $\mathrm{C}$ and/or $\mathrm{N}$ did not affect the proportion of parthenogenetic individuals of oribatid mites. Primarily, fertilization affected the resident species which are mainly sexual. Overall, the results confirm that oribatid mites on the bark of trees are limited by food resources rather than being structured by harsh abiotic conditions.

Results of this study indicate that oribatid mites are well adapted to the harsh conditions on the bark of tree trunks. It has been shown recently that oribatid mites evolved adaptations to the bark habitat convergently (Maraun et al. 2009). Karasawa and Hijii $(2004,2008)$ found more tridactylous oribatid mite species in the stem region than in soil with more monodactylous species, and interpreted this as adaptation to maintain the grip in the arboreal wind and rain-exposed habitat. Further, bark-living oribatid mite species retreat into crevices in the bark to avoid unfavorable conditions (Wunderle 1992). Sexual oribatid mite species also dominate other harsh environments, such as polar regions, deserts (Wallwork et al. 1986), mangroves (Karasawa and Hijii 2004) and saltmarshes (Proches and Marshall 2001). Further, oribatid mites are well adapted to other environmental stresssors such as flooding (Messner et al. 1992), freezing and desiccation (Schatz and Sømme 1981, Sjursen and Sømme 2000, Worland and Lukesova 2000). Such adaptations likely also took place in oribatid mite species 
living on tree trunks. Indeed, bark-living oribatid mites survive freezing and flooding (G. Erdmann, unpubl. data). Therefore, fluctuations in environmental conditions in fact may be of minor importance for oribatid mites on the bark of trees.

Oribatid mites on bark presumably feed mainly on lichens and algae (Erdmann et al. 2007; Fischer et al. 2010a). The limited resource availability could be caused by low amounts, low nutritional values or unpalatability of the resources. All three factors may apply to lichens growing on tree trunks. Most lichens are characterized by slow growth rates, have to deal with low nutrient availability on bark and produce secondary compounds as defense against grazers (Barkman 1958, Lawrey 1983). Oribatid mites were observed to feed specifically on certain lichen species (Reutimann and Scheidegger 1987, Fröberg et al. 2003, Edmund et al. 2008) and to avoid lichens with secondary compounds. Adaptations are needful for oribatid mites on the bark habitat, and sexual species are likely to adapt faster to resources which are difficult to access and to overcome defense strategies of living resources such as lichens more easily than parthenogenetically reproducing species.

Food quality triggers the reproductive mode in cyclical parthenogenetic species (Koch et al. 2009) and is supposed to be a major factor explaining the mode of reproduction in long-lived organisms as concluded by the SRTS (Song et al. 2012). The high fraction of sexual oribatid mites and the resource limitation on bark is conform to these conclusions.

\section{Acknowledgements}

The work has been funded by the DFG Priority Program 1374 "Biodiversity Exploratories" (MA 2461/7-2). Field work permits were given by the responsible state environmental offices of Thüringen (according to $\S 72$ BbgNatSchG). We thank Jens Bast, Bernhard Eitzinger, Bernhard Klarner, Patrick Pachl and Garvin Schulz for assistance in field work and the management team of the "Biodiversity Exploratories" for support of field work and provision of infrastructure.

\section{References}

Barkman, J.J. (1958) Phytosociology and Ecology of Cryptogamic Epiphytes. Van Gorcum and Company N.V., Assen, Netherlands.

Braak, C.J.F. ter, Šmilauer, P. (2002) CANOCO Reference Manual and CanoDraw for Windows User's Guide: Software for Canonical Community Ordination (version 4.5). Microcomputer Power, Ithaca, New York. 
Cotrufo, M.F., De Pascale, R.A., Matteucci, G. (2001): http://www.bgcjena.mpg.de/public/carboeur/ Forcast/publi/index.html

Domes, K., Norton, R.A., Maraun, M., Scheu, S. (2007a) Reevolution of sexuality breaks Dollo's law. Proceedings of the National Academy of Sciences of the United States of America 104, 71397144.

Edmund, L., Seyd, F.L.S., Mark, R.D., Seaward, F.L.S. (2008) The association of oribatid mites with lichens. Zoological Journal of the Linnean Society 80, 369-420.

Erdmann, G., Floren, A., Linsenmair, K.E., Scheu, S., Maraun, M. (2006) Little effect of forest age on oribatid mites on the bark of trees. Pedobiologia 50, 433-441.

Erdmann, G., Otte, V., Langel, R., Scheu, S., Maraun, M. (2007) The trophic structure of bark-living oribatid mite communities analyzed with stable isotopes $\left({ }^{15} \mathrm{~N},{ }^{13} \mathrm{C}\right)$ indicates strong niche differentiation. Experimental and Applied Acarology 41, 1-10.

Fischer, B.M., Schatz, H., Maraun, M. (2010a) Community structure, trophic position and reproductive mode of soil and bark-living oribatid mites in an alpine grassland ecosystem. Experimental and Applied Acarology 52, 221-237.

Fischer, M., Bossdorf, O., Gockel, S., Hänsel, F., Hemp, A., Hessenmoeller, D., Korte, G., Nieschulze, J., Pfeiffer, S., Prati, D., Renner, S., Schöning, I., Schumacher, U., Wells, K., Buscot, F., Kalko, E.K.V., Linsenmair, K.E., Schulze, E.D., Weisser, W.W. (2010b) Implementing large-scale and long-term functional biodiversity research: The Biodiversity Exploratories. Basic and Applied Ecology 11, 473-485.

Froeberg, L., Solhoy, T., Baur, A., Baur, B. (2003) Lichen specificity of oribatid mites (Acari; Oribatida) on limestone walls in the Great Alvar of Öland, Sweden. Entomologisk Tidskrift 124, 177-182.

Heethoff, M., Norton, R.A., Scheu, S., Maraun, M. (2009) Parthenogenesis in Oribatid Mites (Acari, Oribatida): Evolution Without Sex. In: Schoen, I., Martens, K., Dijk, P. (eds.), Lost Sex: The Evolutionary Biology of Parthenogenesis, pp. 241-258. Springer, Dordrecht.

Jongman, R.H.G., Braak, C.J.F. ter, van Tongeren, O.F.R. (1995) Data analysis in community and landscape ecology. Cambridge University Press, Cambridge.

Karasawa, S., Hijii, N. (2004) Morphological modifications among oribatid mites (Acari: Oribatida) in relation to habitat differentiation in mangrove forests. Pedobiologia 48, 383-394.

Karasawa, S., Hijii, N. (2008) Vertical stratification of oribatid (Acari: Oribatida) communities in relation to their morphological and life-history traits and tree structures in a subtropical forest in Japan. Ecological Research 23, 57-69.

Koch, U., von Elert, E., Straile, D. (2009) Food quality triggers the reproductive mode in the cyclical parthenogen Daphnia (Cladocera). Plant-Animal Interactions 159, 317-324.

Koricheva, J. (2002) Meta-analysis of sources of variation in fitness costs of plant antiherbivore defenses. Ecology 83, 176-190.

Lawrey, J.D. (1983) Lichen herbivore preference: a test of two hypothesis. American Journal of Botany 70, 1188-1194.

Macfadyen, A. (1961) Improved funnel-type extractors for soil arthropods. Journal of Animal Ecology 30, 171-184.

Maraun, M., Salamon, J.A., Schneider, K., Schaefer, M., Scheu, S. (2003) Oribatid mite and collembolan diversity, density and community structure in a moder beech forest (Fagus sylvatica): effects of mechanical perturbations. Soil Biology \& Biochemistry 35, 1387-1394.

Maraun, M., Heethoff, M., Schneider, K., Scheu, S., Weigmann, G., Cianciolo, J., Thomas, R.H., Norton, R.A. (2004) Molecular phylogenie of oribatid mites (Oribatida, Acari): evidence for 
multiple radiations of parthenogenetic lineages. Experimental and Applied Acarology 33, 183201.

Maraun, M., Erdmann, G., Schulz, G., Norton, R.A., Scheu, S., Domes, K. (2009) Multiple convergent evolution of arboreal life in oribatid mites indicates the primacy of ecology. Proceedings of the Royal Society B-Biological Sciences 276, 3219-3227.

Maraun, M., Erdmann, G., Fischer, B.M., Pollierer, M.M., Norton, R.A., Schneider, K., Scheu, S. (2011) Stable isotopes revisited: Their use and limits for oribatid mite trophic ecology. Soil Biology and Biochemistry 43, 877-882.

Maynard Smith, J. (1971) What use is sex? Journal of Theoretical Biology 30, 319-335.

Messner, B., Adis, J., Ribeiro, E.F. (1992) A comparative study on plastron structures in mites (Acari). Deutsche Entomologische Zeitschrift 39, 159-176.

Nicolai, V. (1986) The bark of trees - thermal properties, microclimate and fauna. Oecologia 69, 148-160.

Nicolai, V. (1989) Thermal properties and fauna on the bark of trees in two different African ecosystems. Oecologia 80, 421-430.

Norton, R.A., Palmer, S.C. (1991) The distribution, mechanisms and evolutionary significance of parthenogenesis in oribatid mites. In: Schuster, R., Murphy, P.W. (eds.), The Acari. Reproduction, development and life history strategies, pp. 107-136. Chapman and Hall, London.

Norton, R.A., Kethley, J.B., Johnston, D.E., O'Connor, B.M. (1993) Phylogenetic perspectives on genetic systems and reproductive modes of mites. In: Wrensch, D.L., Ebbert, M.A. (eds.), Evolution and diversity of sex ratios, pp. 8-99. Chapman and Hall, New York.

Norton, R.A. (1994) Evolutionary aspects of oribatid mite life histories and consequences for the origin of the Astigmata. In: Houck, M. (ed.), Mites. Ecological and evolutionary analyses of lifehistory patterns, pp. 99-135. Chapman and Hall, New York.

Palmer, S.C., Norton, R.A. (1991) Taxonomic, geographic and seasonal distribution of thelytokous parthenogenesis in the Desmonomata (Acari: Oribatida). Experimental and Applied Acarology $12,67-81$.

Proctor, H.C., Montgomery, K.M., Rosen, K.E., Kitching, R.L. (2002) Are tree trunks habitats or highways? A comparison of oribatid mite assemblages from hoop-pine bark and litter. Australian Journal of Entomology 41, 294-299.

Proches, S., Marshall, D.J. (2001) Global distribution patterns of non-halacarid marine intertidal mites: implications for their origins in marine habitats. Journal of Biogeography 28, 47-58.

Reutimann, P., Scheidegger, C. (1987) Importance of lichen secondary products in food choice of two oribatid mites (Acari) in alpine meadow ecosystem. Journal of Chemical Ecology 13, 363369.

Schatz, H. (2005) Diversity and global distribution of oribatid mites - evaluation of the present state of knowledge. Phytophaga 14, 485-500.

Schatz, H., Sømme, L. (1981) Cold-hardiness of some oribatid mites from the Alps. Cryoletters 2, 207-216.

Scheu, S., Drossel, B. (2007) Sexual reproduction prevails in a world of structured resources in short supply. Proceedings of the Royal Society B - Biological Sciences 274, 1225-1231.

Sjursen, H., Sømme, L. (2000) Seasonal changes in tolerance to cold and dessication in Phauloppia sp. (Acari, Oribatida) from Finse, Norway. Journal of Insect Physiology 46, 1387-1396.

Song, Y., Scheu, S., Drossel, B. (2012) The ecological advantage of sexual reproduction in multicellular long-lived organisms. Journal of Evolutionary Ecology 25, 556-565. 
Subias, L.S. (2004) Listado sistematico, sinonimico y biogeografico de los acaros oribatidos (Acariformes, Oribatida) del mundo (1758-2002). Graellsia 60, 3-305.

Ullrich, W.R., Lazarova, J., Ullrich, C.I., Witt, F.G., Aparicio, P.J. (1998) Nitrate uptake and extracellular alkalinization by the green alga Hydrodictyon reticulatum in blue and red light. Journal of Experimental Botany 49, 1157-1162.

Wallwork, J.A., Macquitty, M., Silva, S., Whitford, W.G. (1986) Seasonality of some Chihuahuan Desert soil oribatid mites (Acari: Cryptostigmata). Journal of Zoology 208, 403-416.

Weigmann, G. (2006) Die Hornmilben (Oribatida). In: Dahl, F. (ed.), Die Tierwelt Deutschlands 76, pp. 1-520. Goecke und Evers, Keltern.

Weismann, A. (1889) Essays on heredity and kindred biological subjects. Oxford University Press, Oxford.

West, S.A., Lively, C.M., Read, A.F. (1999) A pluralistic approach to sex and recombination. Journal of Evolutionary Biology 12, 1003-1012.

Williams, G.C. (1975) Sex and evolution. Princeton University Press, Princeton.

Worland, M.R., Lukesova, A. (2000) The effect of feeding on specific soil algae on the cold-hardiness of two Antarctic microarthropods (Alaskozetes antarcticus and Cryptopygus antarcticus). Polar Biology 23, 766-774.

Wunderle, I. (1992) Die Oribatiden-Gemeinschaft (Acari) der verschiedenen Habitate eines Buchenwaldes. Carolinea 50, 79-144. 


\section{Appendix:}

juvenile - juvenile Oribatida; Achi_col - Achipteria coleoptrata; Cami_seg - Camisia segnis; Cara_lab - Carabodes labyrinthicus; Cham_bor - Chamobates borealis; Cham_cus Chamobates cuspidatus; Cham_pus - Chamobates pusillus; Cham_sub - Chamobates subglobulus; Cymb_cym - Cymberemaeus cymba; Dama_rip - Damaeus riparius; Diap_hum Diapterobates humeralis; Eupe_hir - Eupelops hirtus; Lieb_hum - Liebstadia humerata; Micr_bre - Micreremus brevipes; Minu_pse - Minunthozetes pseudofusiger; Oppi_nov Oppiella nova; Orib_cal - Oribatella calcarata; Phth_lon - Phthiracarus longulus; Sche_asc Scheloribates ascendens; Suct_sub - Suctobelbella subcornigera; Tect_vel - Tectocepheus velatus velatus; Tric_nov - Trichoribates novus; Zygo_exi - Zygoribatula exilis 


\section{Chapter 6}

General Discussion 
Oribatid mites are mainly soil-living microarthropods, but also occur in other habitats, e.g. on tree trunks, in freshwater and in saltmarshes (Walter and Proctor 1999). They are species rich (until today 10,000 species are described), distributed worldwide (Walter and Proctor 1999, Subias 2004, Schatz 2005), and are one of the oldest arthropods, with a Cambrian or Precambrian origin (Schaefer et al. 2010). Sexual and parthenogenetic species coexist in many habitats with parthenogens dominating in soils of temperate regions and sexual species dominating on the bark of trees and in tropical habitats (Bell, 1982). Geographical and cyclical parthenogenesis are not known until today (Norton and Palmer 1991).

Oribatid mites are suitable model organisms to verify theories which try to explain the short- and long-term maintenance of parthenogenetic reproduction, e.g. the 'Structured Resource Theory of Sexual Reproduction' (SRTS) (Scheu and Drossel, 2007). The SRTS is the most recent and an integrative theory aiming to explain the dominance of sexual reproduction. It explains the pattern of cyclical parthenogenesis (Scheu and Drossel, 2007); of geographical parthenogenesis (Song et al. 2010) and of parthenogenesis in multi-cellular long-lived organisms (Song et al. 2012). The SRTS states that sexual populations should prevail in habitats with structured resources or little accessible resources. In such cases sexual species are assumed to more efficiently exploit resources and to use underutilized resources. Sexual populations should therefore mainly be regulated by density-dependent factors. In contrast, parthenogenetic species should prevail in environments with an excess of food where adaptations are of limited use, or in habitats where population density is mainly limited by density independent factors. In the latter case sexual reproduction is of limited use, since populations would not benefit from mixis processes (Scheu and Drossel, 2007). Instead, they should benefit from the two-fold higher reproductive rates.

Using oribatid mites as model organisms for investigating the maintenance of sexual reproduction and interpreting their ecological distribution requires a better understanding of their ecology and phylogeny. The present thesis focused on oribatid mite ecology. In the first part we investigated the trophic ecology of oribatid mites (Chapter 2), and abiotic and biotic factors influencing their density, diversity and community structure in soils of four forest types in Germany (Chapter 3). In the second part oribatid mites were used as model organisms to investigate the pattern of the distribution of sexual and parthenogenetic individuals in soils in different habitats worldwide (Chapter 4), and the effects of nutrient addition on density and the reproductive mode of oribatid mites on tree trunks (Chapter $\mathbf{5}$ ). 


\section{Stable isotope analysis of soil- and bark-living oribatid mites}

The investigation of trophic ecology and the identification of feeding niches of oribatid mites are important to disentangle soil food webs and may help to explain the high oribatid mite diversity. We investigated the trophic ecology of oribatid mites using the method of stable isotope analysis and reviewed previous studies which applied this method (Scheu and Falca 2000, Schneider et al. 2004; Pollierer et al. 2009, Fischer et al. 2010). The method is based on the enrichment of $\delta^{15} \mathrm{~N}$ by about three $\delta$-units and of $\delta^{13} \mathrm{C}$ by about one $\delta$-unit in the body tissue of the consumer in relation to the food-source (DeNiro and Epstein 1981, Minagawa and Wada 1984, Post 2002). Schneider et al. (2004) conducted the first comprehensive study of stable isotope analysis for oribatid mites using $\delta^{15} \mathrm{~N}$ and found values in the range of three to four trophic levels in four forests and classified them as phycophages/fungivores, primary decomposers, secondary decomposers and carnivores/scavengers/omnivores. Our data mainly confirmed the results of Schneider et al. (2004). However, we additionally measured $\delta^{13} \mathrm{C}$ and investigated soil- as well as bark-living oribatid mite species. The use of $\delta^{13} \mathrm{C}$ gave additional information about the trophic ecology of oribatid mites and showed a reduced depletion in adults with endophagous juvenile stages. The specific shift in $\delta^{13} \mathrm{C}$ is caused by incorporation of calcium carbonate as hardening agent in the cuticle in addition to chitin (Norton and BehanPelletier 1991, Pollierer et al. 2009). Analysis of oribatid mite species from the bark of tree trunks showed different $\delta^{13} \mathrm{C}$ and $\delta^{15} \mathrm{~N}$ values compared to soil-living species, indicating fundamentally different trophic niches. The measurement of stable isotopes of potential food sources on tree trunks indicates that many oribatid mite species feed on lichens (Fischer et al 2010a) and on algae (Erdmann, 2007) but not on mosses as the common name 'moss-mites' misleadingly suggests (Fischer et al. 2010a).

Compared with other stable isotope analyses of oribatid mites in soil, the values of $\delta^{15} \mathrm{~N}$ in different forest sites are relatively similar for the same species, indicating constant trophic niches for most species. Two examples are given to illustrate this pattern: Hypochthonius rufulus had highest $\delta^{15} \mathrm{~N}$ values in the studies of Scheu and Falca (2000), Schneider et al. (2004), Pollierer et al. (2009) and our study, indicating predation or scavenging. Platynothrus peltifer had lowest values in all above listed studies which classifies the species as primary decomposer feeding mainly on litter material. The wide range of $\delta^{15} \mathrm{~N}$ and $\delta^{13} \mathrm{C}$ values found in oribatid mite species reflects the high diversity of food sources for the former 'decomposer' taxon.

The method of stable isotope analysis of $\delta^{15} \mathrm{~N}$ and $\delta^{13} \mathrm{C}$ provides information on trophic levels of organisms, i.e. on the range of incorporated food sources resulting in an enrichment 
of $\delta^{15} \mathrm{~N}$ and $\delta^{13} \mathrm{C}$ in the cuticle and body tissue since the last moulting of the animal (Minagawa and Wada 1984). However, the specific food sources, seasonal variation or short-term food preferences remain unclear. Investigating these finer scales of oribatid mite diets should be the next step in uncovering the details of oribatid mite feeding ecology. Further methods are necessary such as molecular gut content analyses (Sheppard et al., 2005; King et al., 2008), fatty acid analyses (Ruess et al. 2005; Haubert et al. 2006) and tracer experiments with isotope-labeled N or C (Simon et al. 2003; Pollierer et al. 2007).

\section{Effect of forest types on oribatid mites}

Oribatid mites are most abundant in temperate and boreal forest soils (Huhta et al. 1986, Maraun and Scheu 2000). Most forests in Europe are managed with varying intensity and manner of management. Management and tree types influence the density and diversity of above-ground animals and plants (Halpern and Spiess 1995, Niemelä et al. 1996, Paillet et al. 2010). Effects on below-ground animals are little investigated but are important to identify since microarthropods in soil contribute to ecosystem processes and services (Lussenhop 1992, Krantz 2009). Here we investigated the density, diversity and community structure of oribatid mites and factors potentially affecting them. The aim of this study was to identify the main factors structuring oribatid mite communities in different forest types.

Four forest types with the most common tree species for Central Europe were studied: $70 \mathrm{y}$ old coniferous age-class forests (Picea abies or Pinus sylvestris, depending on the investigated region); 30 y old and 70 y old beech age-class forests (Fagus sylvatica) and unmanaged beech forests with mature trees being $\sim 120 \mathrm{y}$ old. The experimental setup of the BiodiversityExploratories - a large scale biodiversity monitoring and experimental project (Fischer et al. 2010b) gave the opportunity to investigate the four forest types in three regions in Germany (Swabian Alb, Hainich and Schorfheide) spanning a latitudinal gradient of about $500 \mathrm{~km}$. Investigating this large geographic scale allows general conclusions on the influence of the investigated forest types and related factors on oribatid mites. For relating changes in oribatid mite community structure to environmental factors, the litter mass, soil pH, $\mathrm{C}$ and $\mathrm{N}$ content of litter and fine roots and $C$ content of soil were measured. We assumed highest oribatid mite densities in coniferous forests due to thick litter layer and highest oribatid mite diversity in unmanaged beech forests due to increased habitat diversity.

Oribatid mite densities were highest with $\sim 120,000$ individuals per square meter in coniferous forests and decreased from 30 y old beech with 60,000 individuals per square 
meter over 70 y old beech with $~ 50,000$ individuals per square meter to unmanaged beech stands with $\sim 30,000$ individuals per square meter. The mass of the litter layer correlated positively and the soil pH negatively with oribatid mite density. The litter layer is both habitat and food source for oribatid mites, where they feed directly on or consume the fungi and bacteria which grow on the substrate (Ponge 1991; Schneider et al. 2004). With decreasing pH oribatid mite densities increase. Oribatid mites likely are not acidophilic (Hagvar, 1990) since they have high densities in more base-rich soils in Canada which are post glacially not yet colonized by earthworms (Migge-Kleian et al., 2006). This clearly shows a negative effect of earthworms on oribatid mite densities. High soil pH was positively correlated with earthworm densities (B. Klarner, unpublished data) which may in turn have had a detrimental effect on oribatid mites. The causal factors of macrofauna-mesofauna antagonistic interactions are discussed in detail by Eisenhauer et al. (2010). Mechanical perturbation and resource competition are considered as negative impacts of earthworms on oribatid mites and on mesofauna in general (Eisenhauer et al. 2010).

Diversity of oribatid mites was only little affected by the four forest types, indicating a similar number of niches. However, the community structure of oribatid mites differed, indicating different types of niches. The oribatid mite communities varied strongest between coniferous and beech forests, and changed gradually within the beech forests from $30 \mathrm{y}$ old beech forests over $70 \mathrm{y}$ old beech forests to the unmanaged beech forests. More pronounced than the community shift along the forest types was the difference in oribatid mite community structure between the three regions. Obviously, factors associated with regions were more important in structuring oribatid mite communities than the local effects of forest type within a region. Caruso et al. (2011) concluded that demographic stochasticity and limited dispersal did not fully explain the spatial patterns of oribatid mite communities and suggested that environmental factors and niche-mediated competition play a role in oribatid mite community composition. In our study, the most important factor structuring oribatid mite communities was soil pH. Soil pH affects earthworm densities (Migge-Kleian et al. 2006, Eisenhauer 2010) and influences the main resources of oribatid mites, fungi and bacteria (Baath and Anderson, 2003; Dequiedt et al., 2011). Further studies on microbial communities in soil and effects of earthworms on basal food sources and mesofauna are needed to relate them to oribatid mite community composition. 


\section{Frequency of parthenogenetic oribatid mites related to resources in soils}

The above study identified factors related to oribatid mite densities and communities in forest soils. In a further study we investigated the frequency of sexual and parthenogenetic individuals in these forests in a small scale study, and additionally in a large number of other habitats from all over the world in a meta analysis. Our data supported one assumption of the SRTS which states that parthenogenesis dominates in habitats with an excess of food resources, where adaptations to limited food-resources are not needed (Scheu and Drossel 2007).

Exact food resources of oribatid mites are hard to identify and to quantify (see Chapter 2). Oribatid mites are assumed to live in an 'enemy-free space' (Peschel et al. 2006) due to a variety of defense mechanisms (Raspotnig et al. 2003, Sanders and Norton 2004, Heethoff et al. 2011) and populations are probably predominantly controlled by bottom-up forces. Therefore, we supposed that oribatid mite density reflects the food availability and used it as an indirect measurement for resource accessibility. A better approximation for the amount of resources within a habitat is the respiration of oribatid mite communities since it regards changes in metabolism with body size (Damuth, 1981; Brown et al., 2004). Respiration of oribatid mites was calculated for the small scale study. The relation of oribatid mite density and population respiration to the frequency of parthenogenetic individuals was studied at small scale in two regions in Germany representing a gradient from mull to moder systems (Swabian Alb and Schorfheide). In a meta analysis at a global scale, only the densities of oribatid mites were related to the frequency of parthenogenetic individuals in different habitats such as temperate and tropical forests, fields, meadows and tree trunks.

With increasing oribatid mite densities and respiration the frequency of parthenogenetic oribatid mites increased significantly in the Schorfheide. In the Swabian Alb the same trend occurred but without statistical significance. The effect of resources on oribatid mite densities and respiration might have been superimposed by the higher macrofauna density and activity (e.g., earthworms; see Chapter 3) in the Swabian Alb (B. Klarner, unpublished data) typical for mull systems (Schaefer and Schauermann, 1990). Especially earthworms compete for the same basal resources as oribatid mites, but also disturb the habitat by burrowing, litter comminuting and litter consumption, and perturbation is detrimental for mesofauna communities (Maraun et al., 2003). 
The meta analysis at the global scale included a wider range of habitats, oribatid mite densities and frequencies of parthenogenetic oribatid mites. The correlation between oribatid mite densities and frequency of parthenogenetic oribatid mites was not linear as in the local scale study but logarithmic. The frequency of parthenogenetic individuals was generally high in temperate forests with $60 \%$ and declined below $30 \%$ in meadows, fields, tropical forests and on the bark of trees. This indicates that meadows, fields, tropical forests and the bark of trees are resource limited habitats for oribatid mites and this was confirmed in Chapter $\mathbf{5}$ for the bark of trees. High $\mathrm{C} / \mathrm{N}$ ratios of leaf litter in tropical forests (Haettenschwiler et al. 2011) and the lack of primary decomposers (Illig et al. 2005) indicate the low nutritional quality of tropical forest soils.

The curve of the correlation between oribatid mite densities and frequency of parthenogenetic individuals became flattened at higher densities indicating that with increasing oribatid mite densities the importance of resource limitation declines. Other factors than the amount of resources likely limit the frequency of parthenogenetic individuals at high densities but remain speculative. The coexistence of parthenogenetic and sexual individuals in the same habitat may be due to different feeding niches with distinct resource availability or due to historical resource limitation events with a slow recover of oribatid mites which are typical K-strategists (Norton 1994, Zaitsev et al. 2009).

Overall, the results of the global and local analysis support the assumptions of the SRTS, stating that parthenogenetic organisms prevail in habitats with an excess of food resources.

\section{Tree trunks - a resource-limited habitat for oribatid mites}

In contrast to the soil, tree trunks are dominated by sexual oribatid mites (Erdmann et al. 2006; Fischer et al. 2010) as shown in Chapter 4, indicating resource limitation according to the SRTS. This pattern seems counterintuitive since the bark, in contrast to the soil, is an exposed habitat, assumed to be dominated by harsh abiotic conditions. Harsh abiotic conditions should foster parthenogenetic individuals which recover faster after disturbances due to the two-fold reproductive advantage of parthenogenetic populations (Williams, 1975; Scheu and Drossel, 2007). The resource limitation on oribatid mites on bark was tested in

Chapter 5. Food-resources on the bark of tree trunks were manipulated by fertilization to investigate if oribatid mite densities and the frequency of parthenogenetic individuals increase, indicating food-resource limitation rather than limitation by harsh abiotic conditions. 
The bark of tree trunks was fertilized monthly with an N-source (ammonium nitrate), a Csource (cane sugar), a combination of both ( $\mathrm{C}$ and $\mathrm{N}$ ) dissolved in water and water as control. Treatment effects of samples taken after three and eight months fertilization did not vary and were pooled for further analysis.

Fertilization had no effect on the fraction of parthenogenetic oribatid mites. Primarily, fertilization affected the bark-living oribatid mites which are mainly sexual. The invasion of parthenogenetic species from soil is probably too infrequent to result in an increase of parthenogenetic individuals on bark in the period of the experiment. However, oribatid mite densities increased with $\mathrm{C}$ and $\mathrm{CN}$ fertilization, while $\mathrm{N}$ had no effect. The main effect was caused by $C$. Stable isotope analysis verified the incorporation of $C$ of cane sugar into the tissue of oribatid mites. $\mathrm{N}$ of ammonium nitrate was not incorporated in oribatid mites which is in accordance with the observed oribatid mite densities which were not affected by $\mathrm{N}$ fertilization.

The increase of oribatid mite densities under $C$ fertilization confirmed the assumption of the SRTS. The bark is a resource-limited habitat. The limited availability of food resources could indicate low quantity and/or low nutritional value of algae and lichens which are presumably the main food source (Erdmann, 2007, Fischer et al. 2010). However, also secondary compounds in lichens (serving as repellents against herbivory) reduce the accessibility of the food resource (Lawrey, 1983; Reutimann and Scheidegger, 1987). Sexual individuals have a higher potential to adapt to limited and changing food resources, and to overcome chemical defense compounds (Ghiselin 1974, Bell 1982, Hairston et al. 1999). The high fraction of sexual oribatid mites on tree trunks supports the theory.

The high frequency of sexual oribatid mites in other habitats such as polar regions or saltmarshes may indicate the importance of resource limitation rather than of harsh abiotic factors despite the apparent harsh abiotic conditions.

\section{Conclusions}

The present thesis provided new stable isotope data $\left({ }^{15} \mathrm{~N}\right.$ and $\left.{ }^{13} \mathrm{C}\right)$ of oribatid mites. Stable isotope values of ${ }^{15} \mathrm{~N}$ reflected the wide range of trophic levels and the fundamental difference in diets between soil- and bark-living oribatid mites. The additional measurement of ${ }^{13} \mathrm{C}$ increased the resolution of dietary composition and allowed identification of oribatid mite 
species with endophagous juvenile stages. The data suggest that the classification of oribatid mites as decomposers in most food webs is far too simplistic.

For the first time, oribatid mite density and community structure in different forest types (coniferous and beech forests) from a wide geographical range were investigated in Central Europe, allowing general conclusions on structuring forces. Oribatid mite densities were highest in coniferous forests and were associated with high litter mass and low soil pH. Both factors are intercorrelated with the presence of earthworms preferring high $\mathrm{pH}$ values and processing and reducing the litter. Oribatid mite community composition differed more between regions than between the forest types in the region indicating factors associated with the respective region rather than forest management or tree type influencing oribatid mite community composition.

An important factor structuring oribatid mite community composition, concerning the frequency of parthenogenetic individuals, is the availability and structure of food resources. The relation of oribatid mite densities (used as indirect measurement for resource availability) with the frequency of parthenogenetic individuals was shown in a local analysis for forest soils and globally in a meta analysis including a variety of habitats. The results support an assumption of the SRTS which states that limited resources promote sexual reproduction. Sexual reproducing species have a higher potential to adapt to limited resources and exploit them more effectively than parthenogenetic species. The availability of resources also limited the densities of oribatid mites on tree trunks, as indicated by an increase of oribatid mites due to fertilization with $\mathrm{C}$. This result was counterintuitive since we expected a limitation by harsh abiotic factors in this exposed habitat and expected a high frequency of parthenogenetic oribatid mites. However, the conclusion of the SRTS for habitats dominated by sexual individuals, such as tree trunks, that resources are limiting was confirmed by our results. The application of assumptions of the SRTS on oribatid mite communities is an important step to explain the frequency of parthenogenetic individuals in different habitats.

\section{References}

Baath, E., Anderson, T.H. (2003) Comparison of soil fungal/bacterial ratios in a $\mathrm{pH}$ gradient using physiological and PLFA-based techniques. Soil Biology \& Biochemistry 35, 955-963.

Bell, G. (1982) The Masterpiece of Nature: The Evolution and Genetics of Sexuality. University of California Press, Berkeley.

Brown, J.H., Gillooly, J.F., Allen, A.P. (2004) Towards a metabolic theory of ecology. Ecology 85, 1771-1789. 
Caruso, T., Taormina, M., Migliorini, M. (2011) Relative role of deterministic and stochastic determinants of soil animal community: a spatially explicit analysis of oribatid mites. Journal of Animal Ecology 81, 214-221.

Damuth, J. (1981) Population density and body size in mammals. Nature 290, 699-700.

DeNiro, M.J., Epstein, S. (1981) Influence of diet on the distribution of nitrogen isotopes in animals. Geochimica et Cosmochimica Acta 45, 341-351.

Dequiedt, S., Saby, N.P.A., Lelievre, M., Jolivet, C., Thioulouse, J., Toutain, B., Arrouays, D., Bispo, A., Lemanceau, P., Ranjard, L. (2011) Biogeographical patterns of soil molecular microbial biomass as influenced by soil characteristics and management. Global Ecology and Biogeography 20, 641-652.

Eisenhauer, N. (2010) The action of an animal ecosystem engineer: Identification of the main mechanisms of earthworm impacts on soil microarthropods. Pedobiologia 53, 343-352.

Erdmann, G., Floren, A., Linsenmair, K.E., Scheu, S., Maraun, M. (2006) Little effect of forest age on oribatid mites on the bark of trees. Pedobiologia 50, 433-441.

Erdmann, G., Otte, V., Langel, R., Scheu, S., Maraun, M. (2007) The trophic structure of bark-living oribatid mite communities analyzed with stable isotopes $\left({ }^{15} \mathrm{~N},{ }^{13} \mathrm{C}\right)$ indicates strong niche differentiation. Experimental \& Applied Acarology 41, 1-10.

Fischer, B.M., Schatz, H., Maraun, M. (2010a) Community structure, trophic position and reproductive mode of soil and bark-living oribatid mites in an alpine grassland ecosystem. Experimental \& Applied Acarology 52, 221-237.

Fischer, M., Bossdorf, O., Gockel, S., Haensel F., Hemp, A., Hessenmoeller, D., Korte, G., Nieschulze, J., Pfeiffer, S., Prati, D., Renner, S., Schoening, I., Schumacher, U., Wells, K., Buscot, F., Kalko, E.K.V., Linsenmair, K.E., Schulze, E.D., Weisser, W.W. (2010b) Implementing large-scale and long-term functional biodiversity research: The Biodiversity Exploratories. Basic and Applied Ecology 11, 473-485.

Ghiselin, M.T. (1974) The Economy of Nature and the Evolution of Sex. University of California Press, Berkeley.

Haettenschwiler, S., Coq, S., Barantal, S., Handa, I.T. (2011) Leaf traits and decomposition in tropical rain forests: revisiting some commonly held views and towards a new hypothesis. New Phytologist 189, 950-965.

Hagvar, S. (1990) Reactions to soil acidification in microarthropods - is competition a key factor? Biology and Fertility of Soils 9, 178-181.

Hairston, N.G., Lampert, W., Caceres, C.E., Holtmeier, C.L., Weider, L.J., Gaedke, U., Fischer, J.M., Fox, J.A., Post, D.M. (1999) Lake ecosystems - Rapid evolution revealed by dormant eggs. Nature 401, 446-446.

Haubert, D., Haeggblom, M.M., Langel, R., Scheu, S., Ruess, L. (2006) Trophic shift of stable isotopes and fatty acids in Collembola on bacterial diets. Soil Biology \& Biochemistry 38, 2004-2007.

Heethoff, M., Koerner, L., Norton, R.A., Raspotnig, G. (2011) Tasty but protected: first evidence of chemical defense in oribatid mites. Journal of Chemical Ecology 37, 1037-1043.

Huhta, V., Hyvonen, R., Kaasalainen, P. (1986) Soil fauna of Finnish coniferous forests.Annales Zoologici Fennici 23, 345-360.

Illig, J., Langel, R., Norton, R.A., Scheu, S., Maraun, M. (2005) Where are the decomposers? Uncovering the soil food web of a tropical montane rain forest in southern Ecuador using stable isotopes $\left({ }^{15} \mathrm{~N}\right)$. Journal of Tropical Ecology 21, 589-593.

King, R.A., Read, D.S., Traugott, M., Symondson, W.O.C. (2008) Molecular analysis of predation: a review of best practice for DNA-based approaches. Molecular Ecology 17, 947-963. 
Krantz, G.W. (2009) Form and Function. In: Krantz, G.W., Walter, D.E. (eds.), A Manual of Acarology, 3rd edition, pp. 124-232. Texas Tech University Press, Lubbock.

Lawrey, J.D. (1983) Lichen Herbivore Preference - A Test of 2 Hypotheses. American Journal of Botany 70, 1188-1194.

Lussenhop, J. (1992) Mechanisms of microarthropod-microbial interactions in soil. In: Begon, M., Fitter, A.H. (eds.), Ecological Research, Vol. 23, pp. 1-33. Academic Press, London.

Maraun, M., Scheu, S. (2000) The structure of oribatid mite communities (Acari, Oribatida): patterns, mechanisms and implications for future research. Ecography 23, 374-383.

Maraun, M., Salamon, J.A., Schneider, K., Schaefer, M., Scheu, S. (2003) Oribatid mite and collembolan diversity, density and community structure in a moder beech forest (Fagus sylvatica): effects of mechanical perturbations. Soil Biology \& Biochemistry 35, 1387-1394.

Migge-Kleian, S., McLean, M.A., Maerz, J.C., Heneghan, L. (2006) The influence of invasive earthworms on indigenous fauna in ecosystems previously uninhabited by earthworms. Biological Invasions 8, 1275-1285.

Minagawa, M., Wada, E. (1984) Stepwise enrichment of ${ }^{15} \mathrm{~N}$ along food chains: Further evidence and the relation between $\delta^{15} \mathrm{Nand}$ animal age. Geochimica et Cosmochimica Acta 48, 11351140 .

Norton, R.A., Behan-Pelletier, V.M. (1991) Calcium carbonate and calcium oxalate as cuticular hardening agents in oribatid mites (Acari: Oribatida). Canadian Journal of Zoology 69, 15041511.

Norton, R.A., Palmer, S.C. (1991) The distribution, mechanisms and evolutionary significance of parthenogenesis in oribatid mites. In: Schuster, R., Murphy, P.W. (eds.), The Acari. Reproduction, Development and Life History Strategies, pp. 107-136. Chapman and Hall, London.

Norton, R.A. (1994) Evolutionary aspects of oribatid mite life histories and consequences for the origin of the Astigmata. In: Houck, M. (ed.), Mites. Ecological and Evolutionary Analyses of LifeHistory Patterns, pp. 99-135. Chapman and Hall, New York.

Peschel, K., Norton, R.A., Scheu, S., Maraun, M. (2006) Do oribatid mites live in enemy-free space? Evidence from feeding experiments with the predatory mite Pergamasus septentrionalis. Soil Biology \& Biochemistry 38, 2985-2989.

Pollierer, M.M., Langel, R., Koerner, C., Maraun, M., Scheu, S. (2007) The underestimated importance of belowground carbon input for forest soil animal food webs. Ecology Letters 10, 729-736.

Pollierer, M.M., Langel, R., Scheu, S., Maraun, M. (2009) Compartmentalization of the soil animal food web as indicated by dual analysis of stable isotopes $\left({ }^{15} \mathrm{~N} /{ }^{14} \mathrm{~N}\right.$ and $\left.{ }^{13} \mathrm{C} /{ }^{12} \mathrm{C}\right)$. Soil Biology \& Biochemistry 41, 1221-1226.

Ponge, J.F. (1991) Food resources and diets of soil animals in a small area of Scots pine litter. Geoderma 49, 33-62.

Post, D.M. (2002) Using stable isotopes to estimate trophic position: models, methods, and assumptions. Ecology 83, 703-718.

Raspotnig, G., Schuster, R., Krisper, G. (2003) Functional anatomy of oil glands in Collohmannia gigantea (Acari, Oribatida). Zoomorphology 122, 105-112.

Reutimann, P., Scheidegger, C. (1987) Importance of lichen secondary products in food choice of 2 oribatid mites (Acari) in an alpine meadow ecosystem. Journal of Chemical Ecology 13, 363-369.

Ruess, L., Schuetz, K., Haubert, D., Haeggblom, M.M., Kandeler, E., Scheu, S. (2005) Application of lipid analysis to understand trophic interactions in soil. Ecology 86, 2075-2082.

Sanders, F.H., Norton, R.A. (2004) Anatomy and function of the ptychoid defensive mechanism in the mite Euphthiracarus cooki (Acari: Oribatida). Journal of Morphology 259, 119-154. 
Schaefer, I., Norton, R.A., Scheu, S., Maraun, M. (2010) Arthropod colonization of land - Linking molecules and fossils in oribatid mites (Acari, Oribatida). Molecular Phylogenetics and Evolution 57, 113-121.

Schaefer, M., Schauermann, J. (1990) The soil fauna of beech forests - comparison between a mull and a moder soil. Pedobiologia 34, 299-314.

Schatz, H. (2005) Diversity and global distribution of oribatid mites - evaluation of the present state of knowledge. Phytophaga 14, 485-500.

Scheu, S., Drossel, B. (2007) Sexual reproduction prevails in a world of structured resources in short supply. Proceedings of the Royal Society B - Biological Sciences 274, 1225-1231.

Scheu, S., Falca, M. (2000) The soil food web of two beech forests (Fagus sylvatica) of contrasting humus type: stable isotope analysis of a macro- and a mesofauna-dominated community. Oecologia 123, 285-296.

Schneider, K., Migge, S., Norton, R.A., Scheu, S., Langel, R., Reineking, A., Maraun, M. (2004) Trophic niche differentiation in soil microarthropods (Oribatida, Acari): evidence from stable isotope ratios $\left({ }^{15} \mathrm{~N} /{ }^{14} \mathrm{~N}\right)$. Soil Biology \& Biochemistry 36, 1769-1774.

Sheppard, S.K., Bell, J., Sunderland, K.D., Fenlon, J., Skervin, D., Symondson, W.O.C. (2005) Detection of secondary predation by PCR analyses of the gut contents of invertebrate generalist predators. Molecular Ecology 14, 4461-4468.

Simon, K.S., Benfield, E.F., Macko, S.A. (2003) Food web structure and the role of epilithic biofilms in cave streams. Ecology 84, 2395-2406.

Song, Y., Drossel, B., Scheu, S. (2010) Temporal patterns of resource use in an ecological model of sexual reproduction and geographic parthenogenesis. Evolutionary Ecology Research 12, 831841.

Song, Y., Scheu, S., Drossel, B. (2012) The ecological advantage of sexual reproduction in multicellular long-lived organisms. Journal of Evolutionary Biology 25, 556-565.

Subias, L.S. (2004) Listado sistematico, sinonimico y biogeografico de los acaros oribatidos (Acariformes, Oribatida) del mundo (1758-2002). Graellsia 60, 3-305.

Walter, D.E., Proctor, H.C. (1999) Mites: Ecology, Evolution and Behavior. CABI Publishing, Wallingford.

Williams, G.C. (1975) Sex and Evolution. Princeton University Press, Princeton.

Zaitsev, A.S., Wolters, V., Waldhardt, R., Dauber, J. (2006) Long-term succession of oribatid mites after conversion of croplands to grasslands. Applied Soil Ecology 34, 230-239 


\section{Acknowledgements}

Mein allererster und größter Dank gilt Mark, der mich auf das Thema Oribatiden gebracht hat, das mich nicht wieder losgelassen hat und das nun schon seit 10 Jahren! Ich danke Dir, dass Du mich all die Jahre immer unterstützt hast, in allen Hochs und Tiefs meiner Arbeit, dass Du immer ein offenes Ohr hattest und immer Zeit für Diskussionen und mich mit deiner Begeisterung, deinem Fachwissen und deinen Ideen angesteckt hast. Das alles hat meine Arbeit sehr bereichert und vorangebracht; ich danke Dir sehr!

Stefan, Dir möchte ich danken für das unglaubliche Fachwissen und die Umsorgung, die Du deinen Doktoranden zuteil werden lässt. Bei fachlichen und organisatorischen Problemen konnte ich immer auf Deine Hilfe und Unterstützung bauen. Deine Ideen und Kommentare haben meine Arbeit sehr bereichert.

Dem Exploratorien-Team - vor allem Ilka Mai, Simone Pfeiffer und Sonja Gockel - danke ich für die hervorragende Organisation dieses Mega-Projektes und der schnellen und engagierten Hilfe und Unterstützung bei allen Fragen und Problemen rund um die Probenahme und die Experimente. In diesem Zusammenhang möchte ich auch allen Danken, die bei den Bodenprobennahmen mit dabei waren: Melanie, Bernhard, Bernie, Mark, Liliane, Rosi, Gregor und Ulli.

Frau Fischer und Susanne möchte ich sehr für die zuverlässige Vorsortierung von Unmengen von Proben und dem Einwiegen von Proben danken, das war eine große Hilfe!

Dir, Uli, möchte ich danken für deine Hinweise und Tipps zum Thema Respiration und Dir, Björn, für Deine Hilfe bei statistischen Problemen.

Marko, Dir möchte ich danken für die anregenden Gespräche über Mikroarthropoden und die mir nahezu unbekannte Welt der Pilze.

Olga und Tarek, den fleißigen Heinzelmännchen, möchte ich sehr für die Arbeit am Layout danken, für die Versorgung mit allen lebensnotwendigen Dingen in der Endphase meiner Doktorarbeit und vor allem auch zwischendurch. Simone, Du bist insgesamt eine Bereicherung in jeglicher Hinsicht! Ganz vielen Dank für Deine seelische, moralische und fachliche Hilfe und den angenehmen Ausgleich, wenn die Tage stressig wurden. Ebenso danke ich Kathleen für die schönen Pausen zwischen der Arbeit.

Ina, Dir möchte ich danken, dass Du immer ein offenes Ohr für mich hattest und mir mit Deinen Ratschlägen oft weitergeholfen hast.

Danken möchte ich allen in der AG, die für eine gute Atmosphäre gesorgt haben, in der es sich gut arbeiten ließ. Besonders danken möchte ich: Bernhard dem Großen, Melanie, Patrick, Garvin, Jens und Bernie (ich hoffe ich habe niemanden vergessen) für Eure Hilfe bei den BorkeFreilandarbeiten und auch einfach so, dass ihr da wart.

Das Wichtigste zum Schluss: Meiner Familie danke ich sehr dafür, dass sie mich immer unterstützt hat, mir das Studium ermöglicht hat, geholfen hat, wo es nur ging und immer hinter mir gestanden hat. 


\section{List of publications}

Maraun, M., Norton, R.A., Ehnes, R.B., Scheu, S., Erdmann, G. (2012) Positive correlation between density and parthenogenetic reproduction in oribatid mites (Acari) supports the structured resource theory of sexual reproduction. Evolutionary Ecology Research 14, 311-323.

Erdmann, G., Scheu, S. and Maraun, M. (2012) Regional factors rather than forest type drive the community structure of soil living oribatid mites (Acari, Oribatida). Experimental and Applied Acarology 57, 157-169.

Maraun, M., Erdmann, G., Fischer, B.M., Pollierer, M.M., Norton, R.A., Schneider, K. and Scheu, S. (2011) Stable isotopes revisited: Their use and limits for oribatid mite trophic ecology. Soil Biology and Biochemistry 43, 877-882.

Maraun, M., Erdmann, G., Schulz, G., Norton, R.A., Scheu, S. and Domes, K. (2009) Multiple convergent evolution of arboreal life in oribatid mites indicates the primacy of ecology. Proceedings of the Royal Society B-Biological Sciences 276, 3219-3227.

Erdmann, G., Otte, V., Langel, R., Scheu, S. and Maraun, M. (2007) The trophic structure of bark-living oribatid mite communities analyzed with stable isotopes ( $\mathrm{N}-15, \mathrm{C}-13)$ indicates strong niche differentiation. Experimental and Applied Acarology 41, 1-10.

Glos, J., Erdmann, G., Dausmann, K.H. and Linsenmair, K.E. (2007) A comparative study of predator-induced social aggregation of tadpoles in two anuran species from western Madagascar. Herpetological Journal 17, 261-268.

Erdmann, G.; Floren, A., Linsenmair, K. E., Scheu, S. and Maraun, M. (2006) Little effect of forest age on oribatid mites on the bark of trees. Pedobiologia 50, 433-441.

Submitted:

Ehnes, R.B., Pollierer, M.M., Erdmann, G., Klarner, B., Eitzinger, B., Maraun, M., Scheu, S., and Brose, U. Lack of energetic equivalence in forest soil invertebrates. 


\section{Thesis Declaration}

I hereby declare that the submitted work has been completed by me the undersigned and that I have not used any other than permitted reference sources or materials nor engaged in any plagiarism. All references and other sources used have been appropriately acknowledged in the work. All persons contributing to the manuscripts have been named so.

All data were collected by me except in Chapter 2 stable isotope data of bark-living organisms were provided from B.M. Fischer and data of Steganacarus magnus treated with $\mathrm{HCL}$ were provided from M.M. Maraun. The environmental factors in Chapter 3 were measured in collaboration with M.M. Maraun and B.Klarner. Literature data for the metaanalysis in Chapter 4 were collected by M. Maraun.

I further declare that the work has not been submitted for the purpose of academic examination, either in its original or similar form, anywhere else.

Göttingen, March 2012

Georgia Erdmann

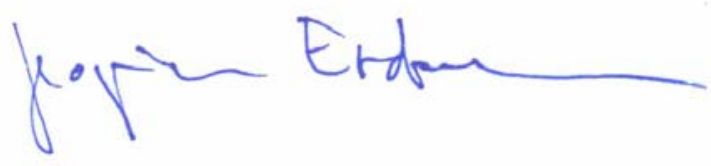

